\title{
The Role of Police and Courts in the Implementation of Domestic Violence Policy in Brazil
}

\author{
Ellen Belchior Rodrigues
}

Follow this and additional works at: https://researchrepository.wvu.edu/etd

\section{Recommended Citation}

Rodrigues, Ellen Belchior, "The Role of Police and Courts in the Implementation of Domestic Violence Policy in Brazil" (2015). Graduate Theses, Dissertations, and Problem Reports. 6521.

https://researchrepository.wvu.edu/etd/6521

This Dissertation is protected by copyright and/or related rights. It has been brought to you by the The Research Repository @ WVU with permission from the rights-holder(s). You are free to use this Dissertation in any way that is permitted by the copyright and related rights legislation that applies to your use. For other uses you must obtain permission from the rights-holder(s) directly, unless additional rights are indicated by a Creative Commons license in the record and/ or on the work itself. This Dissertation has been accepted for inclusion in WVU Graduate Theses, Dissertations, and Problem Reports collection by an authorized administrator of The Research Repository @ WVU.

For more information, please contact researchrepository@mail.wvu.edu. 
The Role of Police and Courts in the Implementation of Domestic Violence Policy in Brazil

\title{
Ellen Belchior Rodrigues
}

\author{
Dissertation submitted \\ to the Eberly College of Arts and Sciences \\ at West Virginia University
in partial fulfillment of the requirements for the degree of
Doctor of Philosophy in
Political Science

\author{
John Kilwein, Ph.D., Chair \\ James Nolan, Ph.D. \\ Phillip Michelbach, Ph.D. \\ Shauna Fisher, Ph.D. \\ Robert D. Duval, Ph.D. \\ Department of Political Science
}
Morgantown, West Virginia
2015

Keywords: Domestic violence, Brazil, decision-making, police, courts, Maria da Penha Law.

Copyright 2015 Rodrigues 


\section{ABSTRACT \\ The Role of Police and Courts in the Implementation of Domestic Violence Policy in Brazil \\ Ellen Belchior Rodrigues}

This dissertation investigated factors that influence the decision-making process of police officers, prosecutors, public attorneys and judges when dealing with cases of domestic violence. The study specifically looked at the types of information the police and the judiciary considered relevant to ask victims when they filed complaints at police stations and at court hearings, respectively. Based on the literature on judicial politics and policing, this research focused on how individuals act as agents, helping or hindering the implementation of the policy. It highlighted the various factors that influence these agents, particularly in the context of small communities such as courts and police stations. Making use of organizational theory, the study was conducted in the state of Espírito Santo, Brazil, which has the highest rate of domestic violence in the country. The description was based on non-obtrusive observations of work routine in police stations and specialized courts and semi-structured qualitative interviews undertaken with police officers, prosecutors, district and defense attorneys, judges, and advocates. The interviews assessed opinions on the law, issues faced by actors, and their suggestions for better implementation. Interactions between police, the judiciary, and victims were assessed by observations. Findings suggest that actors are heavily influenced by an array of factors other than the law, especially their own attitudes toward victims and the accused. Interviewees reported a high level of frustration and reluctance, often asserting that domestic violence cases are relationship problems that should first be addressed to counselors or mediators, not the legal system. This study contributes to the Political Science literature in judicial politics, particularly literature on Law \& Society dealing with the impact of legal decisions in society. 


\section{Table of contents}

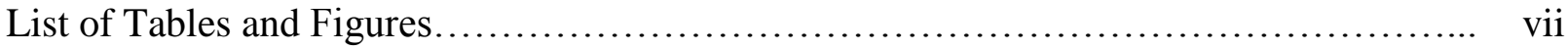

List of Legal Cases............................................................. viii

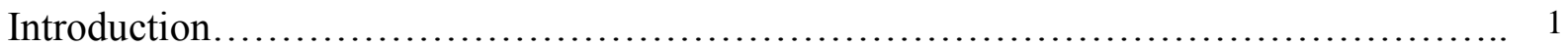

Chapter 1: Development of Domestic Violence Policy in the United States................. 6

Development of Domestic Violence Policy in the United States.................... 7

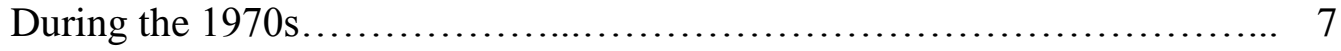

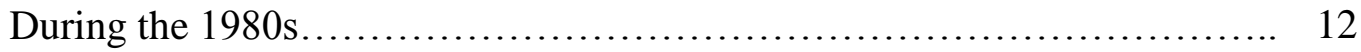

During the 1990s...................................................... 15

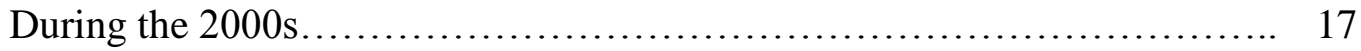

Current Developments in US Domestic Violence Policy.................. 21

Internationalization of Domestic Violence Policy.............................. 24

Human rights perspective and the US legalistic approach......................... 24

Globalization of the US domestic violence policy....................... 26

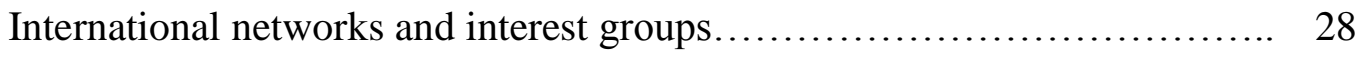

Status of Domestic Violence Worldwide ................................... 30

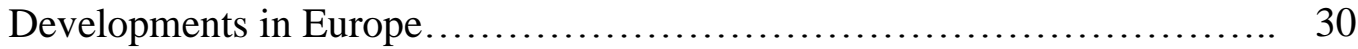

Developments in Asia................................................. 31

Developments in Africa............................................... 33

Developments in the Americas....................................... 35

Conclusion................................................................... 41

Chapter 2: Domestic Violence Policy in Brazil: an Overview........................................ 44 
Brazilian Political and Legal Structures.................................... 45

Police in Brazil............................................................ 46

Brazilian Judicial System......................................... 47

Domestic Violence in Brazil Before the 1980s................................ 49

The 1980s: Brazilian First Women's Police Station............................. 51

The 1990s: Enactment of Law 9099/1995_...................................... 54

Maria da Penha Maia Fernandes and Law 11.340/2006......................... 57

Police procedures according to law $11.340 / 2006 \ldots \ldots \ldots \ldots \ldots \ldots \ldots \ldots \ldots . \ldots \ldots$

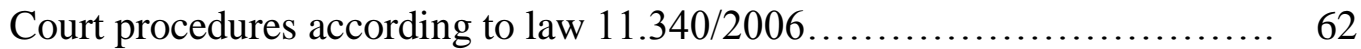

Reluctance and Claims of Unconstitutionality: A Backlash from Judges............. 64

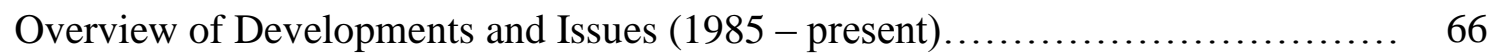

Implementation of the Domestic Violence Policy in Espírito Santo.................. 70

Conclusion...................................................................... 76

Chapter 3: Police Perspective About Domestic Violence Policy.......................... 80

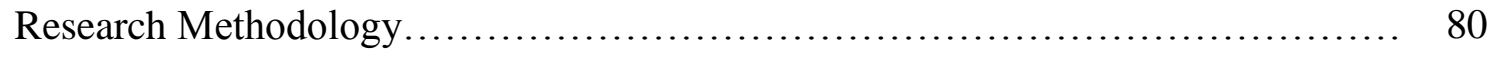

Opinion about Maria da Penha Law........................................ 83

Perceptions about Institutional Constraints .................................. 90

Infrastructure..................................................... 90

Number of staff and workload....................................... 91

Inconsistencies about posting of bail.................................. 93

Different system of case registration.................................. 94

Safety and access to neighborhoods................................ 94 
Factors Influencing Police Decision-Making...................................... 95

Characteristics of the offense............................................ 97

Case 1: Injured victim ignored............................... 97

Case 2: Officer tries to conciliate victim with batterer............... 98

Case 3: Injury case registered as threat.......................... 99

Characteristics of the victim............................................ 100

Characteristics of the batterer.......................................... 104

Attitudes toward domestic violence cases.............................. 105

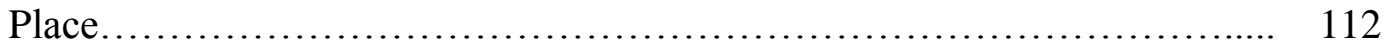

Training .......................................................... 115

Gender............................................................ 116

Experience......................................................... 117

Leadership...................................................... 118

Feelings about Working with Cases of Domestic Violence....................... 119

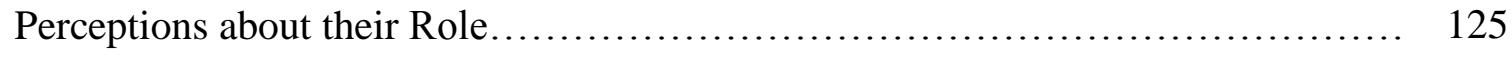

Perceptions about Interaction with Other Institutions........................... 127

Conclusion................................................................ 130

Chapter 4: Court Perspective About Domestic Violence Policy.......................... 133

The Existence of a Community ............................................ 134

Community Culture and Organizational Theory .............................. 137

Law Officials and Opinion about Maria da Penha Law........................... 144

Law Officials and Perceptions about Institutional Constraints.................... 151 
Factors Influencing Prosecutorial Decision-Making........................... 155

Characteristics of the offense ........................................ 157

Characteristics of the victim.................................... 158

Characteristics of the defendant.................................... 162

Attitudes....................................................... 165

Factors Influencing Judicial Decision-Making.............................. 169

Characteristics of the offense..................................... 170

Characteristics of the victim................................... 170

Characteristics of the defendant................................... 176

Attitudes..................................................... 179

Law Officials and Feelings about their Work............................. 188

Law Officials and Perceptions about their Role............................ 190

Perceptions about Interactions with other Institutions...................... 195

Conclusion........................................................ 196

Chapter 5: Conclusions.................................................. 199

References............................................................... 211

Appendix A: Interview Questions........................................ 247

Appendix B: Court Observation Form......................................... 248

Appendix C: Case Observation Form......................................... 249 


\section{List of Tables}

Table 1: Members of the Brazilian Executive, Legislative, and Judiciary at the federal, state, and local levels

Table 2: Comparison of factors influencing decision-making of Brazilian and U.S. police officers who work with domestic violence cases

Table 3: Comparison of factors influencing decision-making of Brazilian and U.S. prosecutors who work with domestic violence cases.

Table 4: Comparison of factors influencing decision-making of Brazilian and U.S. judges who work with domestic violence cases

Table 5: Comparison of factors influencing decision-making of Brazilian criminal justice professionals (police officers, prosecutors, and judges)

Table 6: Comparison of factors influencing decision-making of U.S. criminal justice professionals (police officers, prosecutors, and judges)

\section{List of Figures}

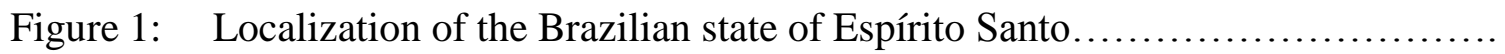

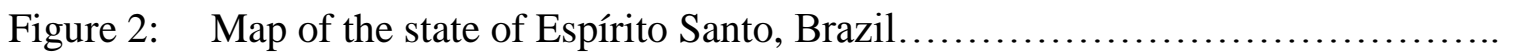




\section{List of Legal Cases}

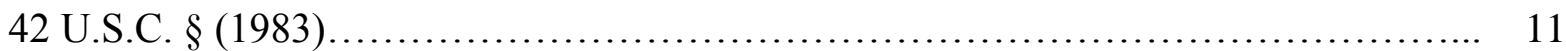

Bruno v. Codd, 47 N.Y. 2d 582 (1977)............................................. 12

Hynson v. City of Chester, PA, 864 F.2d 1026, 1032 (3d Cir.1988)..................... 13

Scott v. Hart (C-76-2395 N.D. Cal. Filed Oct. 28, 1976)............................ 12

State v. Smith, 85 N.J. 193 (1981) 426 a. 2d 38................................... 12

Thurman v. City of Torrington, DC, 595 F. Supp. 1521 (D. Conn. 1984)................. 13

Watson v. City of Kansas City, KS, 857 F.2d 690 (1988).............................. 13 


\section{Introduction}

In 1985, the state of São Paulo, Brazil adopted a new approach to deal with cases of violence between partners. It established special police units known in the country as Delegacia das Mulheres (women's police stations), in an attempt to facilitate a woman's access to justice. Twenty years later, the National Congress enacted law number 11.340/2006. The law was titled Maria da Penha law in tribute to Maria da Penha Maia Fernandes, a victim of domestic violence, who spent twenty years seeking the prosecution of her husband who had seriously injured her while he attempted to kill her. He had shot her as she slept, rendering her paraplegic. He was sentenced to two years in prison (Santos, 2005). Many believed this sentence did not match the gravity of his crime, thus providing the impetus for the law.

Maria da Penha law represented a major change in Brazilian police and court policy regarding acts of domestic violence. The law not only created a new segment of policing, but also criminalized abusive behaviors in relationships that previously were seen as normal in society (Barsted \& Hermann, 1999). Women's police stations have separate units, serve only female victims, are designed to provide a female-friendly environment, and most of the police officers are female. The day after the inauguration of the police unit in São Paulo, 500 women waited in line to file domestic violence reports (Santos, 2005). Unsurprisingly, the years after the adoption of the Law have witnessed a significant increase in the number of cases being reported (Roure, 2009). However, studies suggest that societal bias against domestic violence may be affecting how cases are reported and handled by the police and courts (Alvarez, 1990; Santos, 2005; Roure, 2009).

Santos (2005) highlights the complexity of domestic violence policy in Brazil prior to Maria da Penha. The author investigated the implementation of the 1985 policy in São Paulo 
during its first fifteen years and found that most police officers did not want to work with domestic violence issues and had never received training (Santos, 2005). Many believed that their role was to counsel victims and conciliate them with perpetrators. Yet, politically speaking, the domestic violence policy was a success. The mayor of São Paulo got reelected, the chief of police promoted, and the policy was adopted by other Brazilian states. Later, the national government mandated the creation of specialized police units and courts countrywide. These domestic violence developments in Brazil inspired other countries to adopt the same policy, including Argentina, Chile, Paraguay, Uruguay, Spain, Portugal, India, and Pakistan.

Two recent national studies on the status of intimate partner violence in Brazil have brought to light some challenges facing policy implementation in the country ("Observe: Observatório da Lei Maria da Penha," 2010, 2011). The studies evaluated the number of available specialized police stations, shelters, and specialized courts, as well as the opinion of domestic violence victims about the services. Researchers found that these institutions are unevenly distributed across the country. Out of the 475 police stations in the country, 397 are clustered in urban areas. Also, the two studies found that the majority of police officers did not have any domestic violence training, and rarely interacted with the specialized courts. The studies also established that approximately $30 \%$ of victims were unsatisfied with the services provided. Espírito Santo was not included in the study.

There is not a single study that has investigated what factors influence police and court decision-making processes in domestic violence cases in the country. This research therefore provides a microanalysis of what happens in the police stations and courts. The research attempts to bring to light to what goes on in the hearts and minds of actors involved in the judicial 
process, from their interaction with domestic violence victims and offenders at police stations, to their participation in hearings held in the specialized courts of Espírito Santo.

The study asks the following two related questions: a) Are domestic violence legal professionals in Brazil influenced by extra-legal factors in their decision-making? b) What are the specific factors, legal or non-legal, influencing the decision-making of police officers, prosecutors, public attorneys, and judges who work with domestic violence cases in Espírito Santo, Brazil? These research questions have been informed by the literature on policing and judicial studies on domestic violence. Answering these questions reveals what factors police and courts find relevant in assessing domestic violence cases, and the major challenges they face while implementing the policy. To answer the research questions, the study adopted qualitative methodologies, primarily interviews and personal observations in specialized police stations and courts in the state of Espírito Santo in Brazil.

The chapters in this study are structured to flow from a broad view to the microanalysis of day-to-day activities in the police stations and courts of Espírito Santo. The first chapter provides a macro perspective of how domestic violence policy first evolved in the United States and was then adopted by other countries. The chapter demonstrates the influence of the international community in shaping the creation of domestic violence policy worldwide, including Brazil. The next two substantive chapters focus on how the policy is implemented in police stations and in the courts, based on the narratives of stakeholders, collected through interviews and observations.

Chapter One provides a general overview of the social sciences literature on domestic violence policy. The chapter describes the contribution of the American Women's Rights Movement and more generally highlights the key international moments that shaped the 
development of domestic violence in the world and in Brazil. The purpose of this chapter is to map the historical development of domestic violence, highlighting the transition of domestic violence as a social issue that belonged in the private domain before it entered the public realm. In highlighting this shift, the study locates when and where domestic violence was recognized as a social problem and how its resolution was transferred from households into the hands of the police and the courts. The chapter presents current strategies used to prevent and address domestic violence, such as mandatory arrest, no-drop charges, and restraining orders. In addition, it discusses the influence of activist groups and international networks in policing and litigation responses to domestic violence, and compares responses between countries in the Global North and the Global South.

Chapter Two describes the development and the implementation of the policy in Brazil and Espírito Santo. First, the chapter gives a general overview of the country's political structure, the organization of the police force, and the legal system. Secondly, it provides a historical overview of the political and legal developments that laid the foundation for the adoption and the implementation of domestic violence policy throughout the country. It focuses on three major events: the creation of the first women's police station in 1985; the enactment of law 9099 in 1995, which establishes specialized civil and criminal courts; and the enactment of law 11.340 in 2006, known as Maria da Penha Law, which regulates police and court procedures on cases of domestic violence. Thirdly, having presented the picture of the development of domestic violence policy at international and national levels, the chapter then describes how the national legislation was perceived and implemented in the state of Espírito Santo. The chapter shows how the police and courts received the policy. 
Chapter Three describes the implementation of the domestic violence policy from the police perspective and, thus, identifies the factors that influence police decision-making. In particular, it discusses how they perceive the law and other institutional constraints, their feelings about working with cases of domestic violence, how they see their role in the policy implementation, and their perceptions about interactions with other institutions. The chapter also presents the methodology, which is substantively qualitative, and also explores the policing literature, focusing on the interactions police agents have with victims and batterers. Based on the interviews with police officers, as well as observations of their daily interactions at specialized police stations, the chapter identifies how policy implementation in Brazil supports or contradicts the literature.

Chapter Four focuses on the implementation of the policy in the judicial sphere, focusing on the experiences of prosecutors and judges. The chapter provides a review of the literature on judicial politics, with reference to the current developments in law and society research regarding the use of specialized courts and the paradigm of courts as communities. The chapter then describes what prosecutors and judges find relevant to ask domestic violence victims and defendants during court hearings, highlighting the factors that influence their decision-making. The chapter also demonstrates how the decision-making of prosecutors and judges in Brazil reflects previous findings from the literature, especially as it regards debunking of the legal metaphor. The chapter ends with a discussion of how actors of the judiciary perceive the policy. Chapter Five summarizes the major themes from each chapter and ends with suggestions for future research and recommendation for public policy. 


\section{Chapter 1: Development of Domestic Violence Policy}

Through a historical overview, this chapter narrates the origins of domestic violence policy. In addition, it highlights the importance of international bodies shaping the implementation of the policy in a few countries, framing domestic violence as a human rights issue, instead of a law enforcement issue, as seen in the United States. With this background, the reader will understand why, in chapter two, the Brazilian case is seen as a hybrid of the two frameworks. Although it germinated with an American DNA, it mutated towards the human rights perspective due to rigid sanctions from international bodies.

Chapter one is divided in three parts. The first explains the development of the US domestic violence policy. It presents a general overview of the social sciences literatures, mapping historic developments from the 1970 s to the present. At first, domestic violence was considered a private

matter, a family issue. With the development of the policy, it became a public issue deserving of governmental intervention. However, the first decades were marked by police and court reluctance, which were later addressed through the implementation of a mandatory or preferred arrest policy. This section also describes the consequences of this policy and its impact on police work.

Second, the section on the current developments in US domestic violence policy argues the need of an integrated system to deal with domestic violence. It speaks to how domestic violence is currently addressed through several mechanisms that expedite the delivery of civil and criminal remedies. Most importantly, this section includes the newest developments in policing and judicial literatures. Overall, they aim to shape the future of the policy, claiming the importance of court specialization, the use of coordinated approaches, and the provision of restorative or therapeutic justice. 
The third part of the chapter deals with the internationalization of the domestic violence policy. It first addresses the conflict between the International Human Rights perspective and the American legalistic approach. The section also describes the influence of interest groups and international networks in shaping responses internationally. It follows with an overview on the domestic violence status of a few countries from Europe, Asia, Africa, and the Americas. It concludes highlighting the importance of studying the Brazilian case. Brazil merged the American and international approaches and created a unique model to address domestic violence. Despite lack of studies identifying the factors influencing the outcomes in Brazil, the model has been copied by nine countries and is likely to be implemented by other Global South countries.

\section{The Development of Domestic Violence Policy in the United States}

Prior to the 1970s there were very few legal claims on the subject of domestic violence. This was partly due to society's perspectives on domestic violence as a private matter. This was a period where cases were rarely brought to police attention. Society expected the matter to be resolved at home by the involved husband and wife, and, if the issue was not resolved, the victims were encouraged to find help within the community, including the church (Fagan, 1996). Although the 1641 Body of Liberties of the Massachusetts Bay colonists explicitly forbade striking one's wife (The Massachusetts Body of Liberties, 1641), “prior to the mid-1800s most legal systems accepted wife beating as a valid exercise of a husband's authority over his wife" (Daniels, 1997). By the 1920, wife beating was declared illegal in the entire country (Hanna, 2002), but police arrest remained rare (Feder, 1999). It was during the 1970s that the issue gained broader attention.

US domestic violence policy during the 1970s. The 1970s marked the beginning of domestic violence policy. The decade is also characterized by an increase in awareness regarding 
the status of women in society, and the prevalence and severity of domestic violence. However, the period is also known as a moment of non-intervention. The criminalization of domestic violence was first introduced as a political issue, soon after the government began regulating topics dealing with public morality, social problems, and fear of crime (Dobash \& Dobash, 1979; Gordon, 1988; Pleck, 1989). Despite being recognized as a legitimate issue, it was crucial to implement legal reform and policy change in police and courts across the country, which never happened.

Stakeholders were very reluctant to deal with cases of domestic violence. Social service agencies refused to help (Dobash \& Dobash, 1979; Gordon, 1988; Schneider, 2000), and police and courts denied protection or any type of legal intervention (Reiss \& Black, 1967; Fagan, 1996). The few cases where police responded to a call, officers used mediation as a problemsolving tactic (Sherman, 1992). Arrest was only considered in the most excruciating circumstances, for example if the batterer assaulted the officer (Buzawa \& Buzawa, 1993a). Overall, male batterers were generally dismissed from arrest or prosecution, even in cases of severe injury or death (Pleck, 1987).

Strong belief systems supported their position. Both police officers and court officials not only believed that they should not interfere, but also expected the couple to eventually settle its differences (Gillespie, 1989). Research also shows that they often blamed the wife for the husband's misbehavior (Walker, 1979; Martin, 1983). Perhaps they were also influenced by the recently established law enforcement model, which framed the role of police as crime fighters (Fagan, 1996). According to police officers, domestic violence cases were intractable, they were not challenging, did not provide any personal satisfaction or fulfillment, and were not deserving of police's time and effort since they were not real police work (Parnas, 1967). Officers also 
considered domestic violence cases unpredictable and dangerous, and feared being attacked by one of the parties (Garner \& Clemmer, 1986; Ellis, Choi, \& Blaus, 1993). Later research showed that this belief was nothing more than a myth and did not correspond to the reality of most cases (Garner \& Clemmer, 1986).

The non-intervention approach was also influenced by research conducted by the psychologist professor Morton Bard (1967). His research, one of the first to receive a grant from the US Department of Justice (Fagan, 1996), advocated the use of mediation to settle matters between couples (Sherman, 1992). Liebman and Schwartz (1973) questioned Bard's findings due to problems in his research design and statistical analysis. Nonetheless, mediation became the police's standard approach.

By $1977,71 \%$ of the police agencies with at least 100 employees had already established Family Crisis Intervention Units (Bard \& Connolly, 1978), where officers were trained in conciliation and conflict management skills (Bard \& Zacker, 1971). Training manuals and agencies' policies instructed officers to avoid arrest whenever possible (Fagan, 1996). For example, the 1975 Oakland Police Bulletin instructed the following:

The police role in a dispute situation is more often that of a mediator and peacekeeper than enforcer of the law. Arrest will only aggravate the dispute or create a serious danger for the arresting officers due to possible efforts to resist arrest. Officers should adhere to the policy that arrests are to be avoided, but when one of the parties demands arrest, you should attempt to explain the ramifications of such action (e.g., loss of wages, bail procedures, court appearances) and encourage the parties to reason with each other (as cited in Martin, 1981, p. 93-94). 
The Michigan Police Training Academy instructed officers to a) avoid arrest if possible; b) explain that the procedure of obtaining a warrant was lengthy and costly; c) state their interest in preventing a breach of the peace; d) recommend a postponement; and e) avoid being too harsh or critical (Martin, 1981).

In more serious cases, such as those with violent batterers with history of alcohol or drug abuse, officers were told to refer family to longer-term counseling or treatment (Fagan, 1996). This period of domestic violence policy did allow officers to arrest if they were attacked (Buzawa \& Buzawa, 1990) or witnessed the assault that caused severe injuries (Buzawa \& Buzawa, 1993a; Sherman, 1992). Still, officers tended to use alternative conciliatory measures even in cases where victims had been granted a protection order by the judiciary (Wermuth, 1983; Fagan, 1996). Interestingly, only married victims could request protection orders, as long as they filed for divorce and proved that the husband caused the dissolution of the marriage (U.S. Commission on Civil Rights, 1982; Zorza, 1992). Unsurprisingly, over the years, the number of arrests significantly decreased (Wylie, Basinger, Heinecke, \& Reuckert, 1976). In court, arrested batterers were often dismissed or punished with minor charges (Fagan, 1996; Parnas, 1967). Cases where batterers used a weapon and severely injured victims also received minor sentences (Davis \& Smith, 1981).

Interest groups triggered change by providing not only shelters and clinics, but also forums for discussion where victims and advocates shared problems, developed solutions, and inaugurated the battered women's movement (Erwin, 2006). The movement grew with the input of a multidisciplinary team of professionals who identified the need to address the seriousness of domestic violence. They were women's rights advocates, counselors, researchers, lawyers, workers from rape crisis interventions and shelters, among others. Some of the first measures 
were to develop networks, create more institutions and shelters, and increase awareness about rape, domestic violence, and sexual harassment, issues faced primarily by women.

More importantly, the movement called for the establishment of a domestic violence policy. Accordingly, the advocates adopted political and legal strategies demanding attention from police and courts. Politically, they framed domestic violence as the most serious social problem of their time, deserving of immediate intervention to provide urgent care and long-term protection for women and children (Friday, Metzgar, \& Walters, 1991). They further joined forces with politicians keen to regulate public morality and maintain social control (Erwin, 2006). The strategy proved successful, as public attention and society's consciousness about domestic violence drastically increased. Legal mobilization was used through a series of lawsuits that defined the role of police as gatekeepers of domestic violence cases (Lerman, 1981; Zorza, 1992). To this end, the lawsuits required police to fully protect victims (Schechter, 1982) and adopt a pro-arrest policy in place of the non-intervention conciliatory approach (Sherman, 1992). A majority of the lawsuits claimed the right of protection based on 42 U.S.C. $§ 1983$, popularly known as "Section 1983," a federal law that allows lawsuits for violations of individual constitutional rights. Section 1983 states the following:

Every person who, under color of any statute, ordinance, regulation, custom, or usage, of any State or Territory or the District of Columbia, subjects, or causes to be subjected, any citizen of the United States or other person within the jurisdiction thereof to the deprivation of any rights, privileges, or immunities secured by the constitution and laws, shall be liable to the party injured in an action at law, suit in equity, or other proper proceeding for redress. (42 U.S.C. § 1983) 
One of the first claims was a class action lawsuit, Bruno v. Codd, 47 N.Y. 2d 582 (1977), where, under the instruction of the New York Legal Aid and the Center for Constitutional Rights, battered women charged the New York Police Department with denial of protection by failure to arrest the batterers. Courts demanded that police respond to all domestic violence calls (Zorza, 1992). Another landmark case was Scott v. Hart (C-76-2395 N.D. Cal. Filed Oct. 28, 1976), which resulted in Oakland police reviewing its policy in three crucial ways. First, they needed to inform victims about their right to make a citizen's arrest. Until then, officers listed several impediments, such as loss of time and cost of court proceedings, to discourage victims from pressing charges. Second, officers needed to arrest batterers if they witnessed an assault or misdemeanor, or if there was a probable cause. Finally, officers were obliged to enforce civil restraining orders.

The end of the 1970s, therefore, no longer saw domestic violence as a private issue, but rather a public matter deserving of police and legal intervention. Indeed, governmental and nongovernmental interventions became common. For example, the state of Pennsylvania began issuing protection orders in 1976, a practice that other states adopted throughout the 1980s (Erwin, 2006). Additionally, there was a remarkable increase in access to legal options, protection services and shelters for victims, as well as adoption of mandatory rehabilitation programs for batterers (Buzawa \& Buzawa, 1990).

US domestic violence policy during the 1980s. The 1980s witnessed a rapid growth in research on domestic violence, which further led to institutional change regarding how the issue was addressed. One of the greatest changes occurred in the legal realm. Courts began providing financial assistance for victims and extended protective orders to single women (Zorza, 1992; Harrell, Smith, \& Newmark, 1993), spousal rape was recognized as a crime in State v. Smith, 85 
N.J. 193 (1981) 426 a. 2d 38, and women charged with the killing of their husbands could present history of abuse and threat as a new type of legal defense (Fagan, 1996).

Most importantly, Supreme Court cases revealed police's neglectful position toward victims of domestic violence. In both Thurman v. City of Torrington, DC, 595 F. Supp. 1521 (D. Conn. 1984) and Hynson v. City of Chester, PA, 864 F.2d 1026, 1032 (3d Cir.1988), the Court held that police failed to provide equal protection under the law. Tracey Thurman and Alesia Hynson had restraining orders but kept being harassed by the husband and former boyfriend, respectively. Police consistently refused their calls. Thurman was attacked and stabbed, and Hynson was murdered. In both cases, the court considered the informal practices as policy (Fagan, 1996; Niemi-Kiesilainen, 2001). Although many law enforcement agencies had laws and regulations prescribing protection, officers consistently refused domestic violence calls.

In Watson v. City of Kansas City, KAN, 857 F.2d 690 (1988), it became evident that Nancy Watson was denied equal protection because her complaint was of domestic violence. Ed Watson, her husband and police officer with Kansas City police, kept violating the protection order issued after their divorce. During marriage, he physically abused her several times, including stabbing her once. Nancy was afraid of going to the police, since the last time she did a captain told her, "if you ever call the police again, I will see to it that you are arrested and you'll never see those two kids again" (Watson v. City of Kansas City, KAN, 1988). While driving home with her two children, Nancy noticed Ed following them. She drove to the nearest police station, where Sergeant Woolwerey ensured her safety. Arriving at home, Ed was already there. He forced them into the house, locked the children in their rooms, raped, beat, and stabbed Nancy until the knife broke. While reaching for another knife, Nancy jumped through the window, calling the attention of a neighbor who called the police. Ed left and committed suicide. 
Nancy filed suit against Kansas City, Kan., where it became evident that officers were trained to use arrest only as a last resort in domestic violence cases. The court understood that police were engaging in discrimination and neglect, since they deprived female victims of police protection and failed to enforce criminal laws on batterers (Dalton \& Schneider, 2008). In all cases, the courts considered both formal and informal police practices as expression of policy.

These and several other cases forced police to rethink their approach, ultimately considering the adoption of a new policing style. Along the same time, the entire criminal justice system was being reformed, transitioning toward a law enforcement approach. It was a fertile ground for the upcoming mandatory arrest policy, where arrest would be the first police response in domestic violence cases. Police used deterrence theories to justify its tough on crime approach. Theorists argued that the threat of harsher penalties would deter criminal behavior (Fagan, 1996). It was believed that incarceration, followed by treatment, would significantly reduce incidents of domestic violence (Sherman, 1992; Fagan \& Browne, 1994; Dutton, 1995).

Advancements in research further justified the need for an aggressive pro-arrest response toward domestic violence. Studies revealed that police arrested batterers in not more than $10 \%$ of the cases of domestic violence (Roy, 1977; Bowker, 1982; McLeod, 1983). Friday et al. (1991) found that in $1985,85 \%$ of female murders were committed by a partner or relative. About $25 \%$ of these cases occurred inside the victim's house (Friday et al., 1991). In 1984, the Minneapolis Domestic Violence Experiment investigated what would be the most appropriate police response to cases of domestic violence (Sherman \& Berk, 1984). Researchers conducted a controlled experiment with arrested men charged with spousal abuse, and observed a decrease in abuse after the arrest. State legislators and police executives across the nation rapidly adopted pro-arrest policies across the nation. Around the same year, the United States Attorney General's Task 
Force on Family Violence published a report endorsing the Minneapolis experiment. The report reflected the government's position and determined police and courts should embrace a proarrest policy and provide greater protection to victims of abuse (Frantzen \& San Miguel, 2009).

Pro-arrest or mandatory arrest policies were seen as the appropriate police response to cases of domestic violence. Legal reform was soon achieved in 47 states as state laws criminalized domestic violence, guaranteed assistance for victims (Lutze \& Symons, 2003), and allowed police officers to make a warrantless arrest regardless of a victim's consent (Friday et al., 1991). It was assumed that an arrest would work as deterrence of domestic violence in all cases (Jolin \& Moose, 1997). Nevertheless, this was proved false in later research. Another important change was the creation of domestic violence units in prosecutor's offices. Some cities also provided psychological treatment for batterers. Most importantly, victims had access to expedited provision of protective and restraining orders and financial assistance, independently of their marital status (Grau, Fagan, \& Wexler, 1985; Fagan, 1996). By the mid-1980s, almost $50 \%$ of police agencies in cities with at least 100,000 habitants had adopted a pro-arrest policy (Sherman \& Cohen, 1987; Friday et al., 1991). In 1988, a similar study found that $90 \%$ of police departments had a mandatory arrest policy (Sherman, 1992).

Despite the adoption of pro-arrest policies, arrest percentages remained low, suggesting that police officers were still reluctant to deal with domestic violence cases. During the late 1980s, further studies confirmed that even in cases where victims were severely injured, arrest percentages remained on the average of $18 \%$ in agencies that adopted the mandatory arrest policy (Balos \& Trotzky, 1988; Ferraro, 1989).

US domestic violence policy during the 1990s. The 1990s was marked by a period of growing research interest, as well as the enactment of the Violence Against Women Act 
(VAWA), perhaps the biggest achievement in domestic violence policy in the United States. In 1991, approximately 3,000 women were killed by their partners (Friedman \& Shulman, 1990). Soon after the implementation of the mandatory arrest policy, many studies replicated the Minneapolis experiment and found diverging results, suggesting uncertainties about the effectiveness of a mandatory-arrest policy (Bourg \& Stock, 1994; Johnson, 2010). The literature continued to evolve, revealing lack of unanimity in the research community (Dunford, 1990; Dunford, Huizinga, \& Elliott, 1990; Berk, Campbell, Klap, \& Western, 1992; Pate \& Hamilton, 1992; Hirschel \& Hutchison, 1996), and making harsh criticisms about voids in the system (Binder \& Meeker, 1988; Elliot, 1989; Lempert, 1989).

One of the greatest developments in the battle against domestic violence occurred in 1994, when the federal government passed the VAWA (Barnes, 1998; Frantzen, San Miguel, \& Kwak, 2011). The VAWA reflected the position of the federal government regarding domestic violence and strongly reinforced the adoption of the mandatory arrest policy throughout the country. It emphasized the need to facilitate access to police and legal remedies, and urged the continuous development of further mechanisms to extend protection and eligibility of victims. The act expanded the eligibility to unmarried and same sex couples, besides providing a better understanding on the complexity of the issue (Mignon \& Holmes, 1995; Fagan, 1996). According to the Act, officers should not attempt to reconcile or mediate parties. Officers did not have to witness the assault; they could proceed with the arrest if there was a reasonable cause to believe that a felony, misdemeanor, or violation of a restraining order occurred (Walsh, 1995).

As a result of VAWA, there was an increase in the number of civil and criminal sanctions, the provision of investigative services, mandatory treatment for the batterer, and the specialization of courts and special forums created specifically to deal with cases of domestic 
violence (Hilton, 1993). There was also the development of coordinated services between police, the prosecutor's office, and the courts (Lerman, 1992), which started adopting protocols, forms, uniform report filing systems, and an array of procedures to compile data and track evidence of domestic violence (Erwin, 2006; Schneider, 2000). By 1994, Bourg and Stock (1994) observed a $30 \%$ increase in the number of arrests in domestic violence cases reported in a county in Florida.

The VAWA moreover established the provision of state funds directed at training and other forms of professional development, as long as the state adopted at least a pro-arrest policy. Part of the funding derived from charges issued to obtain marriage licenses (Fagan, 1996). With the funding and training, police officers were able to better identify the seriousness of domestic violence, accept their role in addressing the issue formally, and improve the treatment of victims, further legitimizing the acceptance of domestic violence as a social problem. By 2001, all American states had adopted at least a pro-arrest policy and many preferred the mandatory arrest approach. States also reformed their legislation, clearly stating their response regarding domestic violence cases (Niemi-Kiesilainen, 2001).

US domestic violence policy during the 2000s. The decade of 2000s was characterized by severe criticisms against the mandatory arrest policy. One of the first criticisms was due to an unexpected consequence of the policy: the increase of the female incarcerated population. For example, a significant increase on the number of women arrested for cases of domestic violence was observed in California (DeLeon-Granados, Wells, \& Binsbacher, 2006). According to these authors, "aggregate felony domestic violence arrest rates more than doubled from 1987 to 1997 and then declined 23\% from 1997 to 2000 in the state and female arrest rates for domestic violence increased more than 500\%, while male rates increased 136\%" (DeLeon-Granados, Wells, \& Binsbacher, 2006, p. 359). 
Police officers were arresting both partners during domestic violence calls (Buzawa \& Buzawa, 2003). They argued that often both parties were physically injured or actively involved in the fight, and wished to provide both parties with the services and resources of the criminal justice system (Finn \& Bettis, 2006). Research also found that officers would rather leave the determination of guilt to the prosecutor (Miller, 2001), and prosecutors preferred to leave the decision to the judges (Martin, 1997b). Moreover, it was found that more experienced officers were most likely to make dual arrests (Finn, Blackwell, Stalans, Studdard, \& Dugan, 2004). Further research found that the increase in the number of women arrested was mainly from domestic violence cases, as indicated by the 2000 National Incident Based Reporting System (NIBRS) (Hirschel, Buzawa, Pattavina, \& Faggiani, 2008). The increase in the number of dual arrests was observed in most states, some reporting a 70\% increase (Buzawa \& Buzawa, 2003).

Very concerned with this unforeseen outcome, advocates requested a change on the wording of the law to mention the arrest of the primary or predominant aggressor (Stalans \& Finn, 2006). Another measure to curb the problem was a pursuance of a pro-arrest policy that considered the victim's wishes (Johnson, 2007). Advocates aimed at reestablishing the status of domestic violence as a gendered crime (Erwin, 2006).

The mandatory arrest policy was further criticized for ignoring the multiple profiles of aggressors (Chalk \& King, 1998) and the different types of violence (Kelly \& Johnson, 2008). The use of one generic approach to all cases also brought unexpected consequences. As studies demonstrated, there is a great likelihood of recurrence and increase in domestic violence when the batterer is unemployed (Sherman, 1992) or loses child custody (Martin, 1997a). Furthermore, it was found that arrest had no deterrence effect on batterers with mental disorders, given their patterned violent behavior and inability to rationalize coping mechanisms during an incident of 
abuse (Dutton, 1995; Fagan, 1996). In these cases, mandatory arrest policy could likely increase the risk of victimization (Dunford, 1990; Dunford et al., 1990; Hirschel \& Hutchinson, 1991).

It was also argued that the mandatory arrest policy ignored victim's wishes (Austin \& Buzawa, 1993b) since police officers were required to apply the law and arrest the batterer, independently of the preference of the victim (Sherman, 1992). Studies have also pointed to further victimization of minorities, especially women of color, who stopped relying on the police for fear that the arrest would result in greater retaliation by the batterer (Richie \& Kanuha, 1993; Richie, 1996). Officers, prosecutors, and judges started engaging with victims who were reluctant to cooperate with case proceedings (Hoyle, 2000). This problem brought to question whether the victim's wishes should be taken into consideration (Kirsch, 2001; Hickman \& Simpson, 2003). According to Hickman and Simpson (2003), the denial of a victim's preference could discourage them from future police utilization. On the other hand, as studies suggest, when a victim's preference is taken into consideration, the victim is more likely to reutilize police work, be cooperative and also feel empowered (Hoyle, 2000; Hickman \& Simpson, 2003; Kingsnorth \& McIntosh, 2004). Hirschel et al. (2008) go beyond, arguing that officers should consider a victim's preferences, in addition to the characteristics of the offender and the offense, as well as the relationship between the victim and the offender, before determining the arrest.

Additionally, the mandatory arrest policy was criticized for taking away an officer's discretionary power. The policy caused major impact on the decision-making of officers, prosecutors and judges, which were now required to take measures often against their values (Walker, 1981; Breci, 1989; Belknap \& McCall, 1994). Research with police especially revealed a great deal of frustration (Walker, 1981; Horwitz et al., 2011) and reluctance in dealing with domestic violence cases (Wallace, 1996). As noted earlier, research in early in 1981(Walker, 
1981) already had indicated that an officer's reaction to domestic violence policy could significantly alter the outcome of the cases. At the time, the 30 officers interviewed believed that they should not intervene in domestic disputes, given their little, if any, potential impact in conflict resolution (Walker, 1981). More recently, Horwitz et al. (2011) facilitated a focus group discussion where 22 officers shared their frustrations. Even though they had a greater sense of accomplishment, they emphasized the urgent need of better communication and integration between police, courts, and community. They also called for more training and debriefing meetings to facilitate their understanding toward a more uniform approach.

These criticisms and unexpected outcomes made it clear that legal reform in statutes and training manuals were not sufficient to successfully address domestic violence, as advocates had expected. It also suggested that, despite institutional change, much still had to be done to substantially change the behavior of stakeholders. For example, police widely adopted the community-policing model, but it had little impact on the routine at agencies (Clement, Tatum, Kruse, \& Kunselman, 2009). It was believed that the introduction of the community-policing model would challenge the mandatory arrest policies and return the power of discretion to the police (Jolin \& Moose, 1997). The philosophy of community-policing model inherently opposes the law enforcement approach in many ways. Successful policing is not determined by the number of arrests, but for its preventive role in crime. It highlights the importance of police discretion, victim empowerment, and the mutual cooperation between community and police. It also places higher consideration on a victim's preference and the use of alternative measures to solve disputes. Martin (1997a) argues that the community-policing model is a better tool to address and curb domestic violence. The model would ultimately reflect in community satisfaction and a higher sense of police accountability. 
Finally, the outcomes of mandatory arrest policy also indicate that officials are not solely influenced by law. In fact, a great part of their reluctance might be motivated by various other factors. Indeed, further research has investigated the influence of various aspects determining the decision-making process of police officers, prosecutors and judges (Wallace, 1996; Frantzen, San Miguel, \& Kwak, 2011). This topic will be further explored below through a review of policing and judicial literatures.

Current developments in US domestic violence policy. As shown in the above sections, domestic violence is widely recognized as a complex social problem. The problem has thus received increased legal attention. Relatedly, the legal concept encompasses not only physical injury, but also any form of harassment, sexual assault, threats of violence and intimidation, property destruction, and stalking (Mignon \& Holmes, 1995; Robinson, 2000; Dawson \& Dinovitzer, 2001; Hines \& Malley-Morrison, 2005; Kelly \& Johnson, 2008). Advocates have expanded the concept to include almost any act that reflects control of one party against another, including economic, verbal, or psychological abuse (LaViolette \& Barnett, 2000). Persons who have or have had an intimate relationship can initiate a domestic violence claim. It is the understanding of the federal government that the law must be interpreted broadly, meaning that eligibility is given to all that fit that criteria, including unmarried, gay or lesbian couples, cohabitants or not, or in a dating relationship (Robinson, 2000; Clifford, Hertz, Doskow, \& Curry, 2007).

There has been an emphasis on expediting the process involving the delivery of criminal and civil remedies (Ursel, 2002). Recent developments include emergency protection orders, often facilitated by risk assessment protocols and other measures developed by social workers to evaluate the victim (Shenoy, 2007). These documents are often provided through specialized 
courts, created with the sole purpose of attending cases of family violence (Mazur \& Aldrich, 2003; Eley, 2005). Training updates are another needed measure (Johnson, 2010), especially given the hindering biases that many officers and other professionals of the criminal justice system still carry regarding the issue of domestic violence (Wilson, Martinez, \& Huisman, 2005).

Aiming to shape the future and direction of the US domestic violence policy, most recent developments in the policing and judicial literatures offer many critiques of the way the criminal justice system is currently working. Most of these literatures argue for the need of more specialized domestic violence courts, use of therapeutic or restorative justice, and better integration between police, courts, community, and other service providers (Johnson et al., 1994; Roberts \& Fields, 2002; Lazarus-Black, 2007; Suk, 2009; Lockhart \& Danis, 2010; Garcia \& McManimon, 2011).

Over the years, courts have faced many changes due to several reforms implemented since the 1980s (Hays, 1978; Feeley, 1983). Many courts have rules and organizational structures significantly different from decades ago. Tobin (1999) notes important changes and shifts that have occurred in the adversarial system and judicial roles. The author identifies a focus on the satisfaction of the client and the adoption of problem-solving roles. In particular, the adversarial system allows individuals to have more input in proceedings and encourages judges to embrace a social role.

The criminal justice system has evolved toward specialization, creating specialty courts, also known as problem-solving courts, to deal strictly with certain types of crimes, such as drug and community courts (Tobin, 1999; Mirchandani, 2006). In many jurisdictions, criminal legal reforms have yielded the creation of domestic violence courts (Keilitz, 2000; Shaffer, 2004), a 
progression of the reforms initiated during the 1980s. Typically, a domestic violence court facilitates the provision of several services, including the issuance of protection orders, provision of psychological counseling and welfare support, expedited trial, and communication between police and courts for the connection of cases in the family, civil, and criminal spheres (Mazur \& Aldrich, 2003; King \& Batagol, 2010).

Accordingly, a coordinated approach attempts to provide a more restorative (Burkemper \& Balsam, 2007) or therapeutic justice (Shaffer, 2004; Prescott, 2009). Restorative justice focuses on the needs of victims, as well as offenders, and expects that measures will positively affect the community of those involved in the crime, voluntarily or not (Burkemper \& Balsam, 2007). Similarly, therapeutic jurisprudence incorporates a series of decision-making tools targeting victim safety and offender accountability. It includes the use of supervision and monitoring, sentences to attend counseling and therapy, rewards and sanctions toward rehabilitation and accountability of the defendant during the process (King \& Batagol, 2010). Overall, offenders have reacted positively to a requirement to appear in court to inform the judge about their rehabilitation process (Rempel, Labriola, \& Davis, 2008). An integrated community response, therefore, better protects victims and further legitimizes the governmental position against domestic violence (Zorza, 1992; Shaffer, 2004).

Opposing the implementation of integrated or coordinated approaches, Mirchandani (2006) argues that the new model provides a transition in the legal role of the state, taking on a social approach that is unfamiliar to the role of the law. Traditionally, courts handle cases aiming at efficiently expediting the process and exerting social control, not social change. As Prescott (2009) argues, this model drastically changes the role of the judge once defendants have an input in the development and implementation of sentences. MacDowell (2011) further argues that an 
integrated system that merges criminal and civil cases under one procedure confers an obstacle for litigation strategies, compromising the effectiveness of both civil and criminal instruments. Some have also argued that while traditional courts focus on adjudication and use a retributive system, specialized domestic violence courts shift toward a rehabilitative model aimed at positively influencing their litigants (Berman \& Feinblatt, 2001). Another critique is that court reforms reduced batterer's procedural justice and it should be realigned to provide a sense of fairness to the victims (Epstein, 1999, 2002).

Despite these critiques, a majority of national and international studies welcome new models, once they bring holistic approaches to the problem of domestic violence and empower participants toward positive transition out of violence, instead of treating them as mere victims and offenders (Lewis, Dobash, Dobash, \& Cavanagh, 2001). Gover, MacDonald, and Alpert (2003) investigated a domestic violence court from South Carolina and verified that it was effectively applying a localized systematic model that resulted in greater enforcement and victim safety. Lightman and Byrne (2005) validate this model by advocating for an integrated approach targeting domestic violence and substance abuse. Literature on the globalization of domestic violence policy supports the view that holistic approaches better deal with cultural issues and effectively facilitate policy implementation.

\section{Internationalization of Domestic Violence Policy}

International human rights perspective and the US legalistic approach. Over the years, international advocates and nongovernmental organizations have had a great influence on the dissemination of domestic violence policy around the world. The United Nations (UN) has been one of the most powerful institutions in framing domestic violence as a human rights issue (Erwin, 2006). The UN argues that domestic violence is more than a criminal justice issue; it is 
an aspect of structural and societal gender subordination, rooted in several spheres, including economy, politics, culture, and religion ("Declaration on the Elimination of Violence Against Women,” 1993). Thus, police and judiciary solely cannot provide equal protection since particular groups of women are more vulnerable to gender-based violence. Such is the case of women who are poor, disabled, incarcerated, minority, migrant or refugee, or live in a war zone (Erwin, 2006).

Domestic violence is one of the leading causes of female murder around the world (Human Rights Watch, 2012). An estimated 40-70\% of female murders in Australia, the United States, Canada, South Africa, and Israel is attributed to domestic violence (World Health Organization [WHO], 2005). Moreover, between $29 \%$ and $62 \%$ of physical injury to women in Bangladesh, Brazil, Peru, Namibia, Samoa, Serbia-Montenegro, Thailand, and Tanzania, and $71 \%$ in Ethiopia is linked to this kind of violence (WHO, 2005). As an acknowledgement of this reality, the human rights perspective pushes for a collective approach, applied through integrated solutions, that addresses aspects not only of safety and punishment, but of sustainability and affirmation of first, second, and third generation rights, respectively related to individual, economic, social, and developmental rights (Rich, 2002).

In contrast, the United States uses an individualized, legalistic approach rooted more on the achievement of civil and political rights, classified mainly as first generation rights. Historically, this approach framed domestic violence as an individual issue to be solved at the criminal justice level once women's rights were infringed. Thus, criminal law was used to legitimize state intervention in a (until then) private sphere. The criminalization of domestic violence gave rise to punishments that the police and the judiciary were expected to enforce. Among the positive outcomes, society became more conscious of the criminality of domestic 
violence, and the government legitimized its position in fight against domestic violence, punishing it with arrest, prosecution, and conviction. The American perspective rapidly evolved through the enactment of laws and regulations that were quickly implemented throughout the country.

Globalization of the US domestic violence policy. Many countries, including Albania, Armenia, Bulgaria, Poland, Macedonia, Moldova, Nepal, Romania, Ukraine, Uzbekistan, Puerto Rico, and Brazil, considered the US policy a successful experience and started implementing a similar approach (Erwin, 2006). Harrington and Wimmer (2008) describe the positive outcomes of a partnership project developed in Romania between the United States Agency for International Development (USAID), Cornerstone University, and the Veritas Foundation, a local non-profit organization. Under the consultancy of American professionals, the program was established in 2003 and provided services for victims of domestic violence. Shahidullah and Derby (2009) studied the evolution of domestic violence policy in other countries including India, Japan, Bangladesh, Ghana, and Brazil, and concluded that these countries had a similar legislative development, despite differences in the degree of punishment. Overall, they defined and criminalized domestic violence, differentiated it from other types of interfamily violence (such as elderly or child abuse), introduced several provisions (arrest, investigation, protection, restraining orders, victim assistance, rehabilitation), and training. Bangladesh prescribed more punitive laws, with provision for the death penalty for perpetrators with a criminal history of twelve offenses.

Soon after the internationalization of the US policy many considered it problematic. According to Erwin (2006), countries started adopting the policy and subsequently started identifying different causes and consequences of domestic violence. While the United States 
developed solutions by focusing on the achievement of individual rights, other countries needed to develop solutions to address victim's economic, social, and developmental rights. In many instances when aggressors were arrested, victims were left without houses or financial means to sustain the family. In most cases, the victims lacked access to health, education, and didn't have work experience or community support. Thus, the US approach offered no solution to the reality of most countries. Through the lens of US policy, domestic violence is an issue of power and control that requires the activation of the criminal justice system and the imposition of harsh punishment. Through a human rights perspective, advanced by international activists, domestic violence is an issue of female subordination tied with social, economic, political, and cultural issues.

There were also concerns about police integrity in many countries. Examples include the mistreatment of Aboriginal women by Australian police (Andrews, 1997), occurrences of rape and torture inflicted by Turkish police, and corrupt Pakistani police officers dismissing cases of honor killings with justification that women deserved to be killed for attempting to leave their husbands (Dauer, 2001). Thus, states are challenged to deal with cultural, economic, and political issues in order to shape police practice toward the ideal. As such, many states are unwilling to reform criminal and family laws that inherently sustain the women's state of subordination (Hajjar, 2004). Similarly, the police and judiciary are governed by their own values and ideologies regarding gender roles, and refuse to document victim's accounts or to officially recognize the criminality of certain forms of violence (Erwin, 2006).

As pointed above, even in the United States, the implementation of domestic violence policy was considered problematic because of the mandatory arrest policy and its divergent and unexpected consequences. In some cases, it reduced recidivism rates and gave more protection to 
the victims. In others it did not deter the risk of violence, as the perpetrator left the prison and killed the victim. Another problem was the occurrences of dual arrests and the increase of the population of female incarceration, which quadrupled due to a gender-neutral policy, not to mention the occurrences of sexual abuse infringed by male guards upon female prisoners (Dauer, 2001).

\section{International networks, interest groups and the criminalization of domestic violence.}

In the meantime, the United Nations (UN) was spearheading an international campaign against domestic violence, culminating with the enactment of the UN Declaration on the Elimination of Violence Against Women (1993). During that time many countries started adopting the human rights perspective. At first, many countries, including Brazil, that had adopted the American legalistic approach switched to the human rights approach (Erwin, 2006). The Declaration was an international agreement where countries became legally responsible to take initiatives to end violence against women. The term violence against women was defined as the following:

Any act of gender-based violence that results in, or is likely to result in, physical, sexual or mental harm or suffering to women, including threats of such acts, coercion or deprivation of liberty, whether occurring in public or private life. ("Declaration on Elimination of Violence Against Women," 1993)

As of 2007, 185 countries had signed the declaration and, of these, 87 passed domestic violence legislation (Shahilulah \& Derby, 2009). The enactment of the declaration was part of a larger ongoing historic process that established the birth of the International Women's Movement (Zorn, 1999). Shahidullah and Derby (2009) note that this process started unfolding in 1888 with the formation of the International Council of Women. Later, the Council established the Feminist International Alliance of Women for Suffrage and Equal Citizenship in 1904, and 
the Women's International League for Peace and Freedom in 1915. The UN Declaration of Human Rights in 1948 pushed the internationalization of human rights and further introduced women's issues in the international agenda. These issues were consolidated in 1981, when the 1979 United Nations Convention on the Elimination of all forms of Discrimination Against Women (CEDAW) came into force. Later in 1985, the United Nations Decade for Women: Equality, Development and Peace Conference occurred in Nairobi, Kenya.

Today, CEDAW is considered a landmark achievement (Zorn, 1999; Hajjar, 2004; Shahidullah \& Derby, 2009). It made states responsible, under international law, to take all appropriate measures to end all forms of discrimination, highlighting their political, economic, social, and cultural aspects. However, CEDAW did not explicitly describe domestic violence as a human rights violation (Erwin, 2006). The 1993 Declaration on the Elimination of Violence Against Women, on the other hand, specifically addressed domestic violence as a major human rights issue worldwide ("Declaration on the Elimination of Violence Against Women," 1993).

Another important international event on domestic violence was the 1995 United Nations World Conference on Women in Beijing, which greatly shaped public policies internationally regarding the issue. It clarified many concerns regarding the issue, its contributing factors and ways of governmental intervention. Through the use of international law, the United Nations World Conference on Women in Beijing shaped public policies and introduced the concept of domestic violence as a human rights issue that demanded immediate governmental attention (Bunch, 1990). According to Shahidullah and Derby (2009), the United Nations Development Fund for Women and the World Health Organization provided further support in governance and policy-making. The World Bank, European Commission, Inter-American Commission on 
Human Rights, Asian Development Bank, and the Organization of African Union also provided support in research and data gathering.

Today, most countries have criminalized domestic violence and adopted more detailed legislation with provisions for the various complex scenarios and degrees of violence. As the US government attempts to connect the issue of domestic violence with an international human rights perspective (Erwin, 2006), the most recent literature focuses on the different realities abroad and further raises issues related to implementation. For example, Middle Eastern countries are the targets of American foreign policy (Hajjar, 2004). The status of women in those countries was a major issue in the foreign policy discourse of former president George W. Bush (Erwin, 2006). As of the year 2000, only 17 states had not signed CEDAW, and 11 of them predominantly Muslim nations (United Nations, 2000). However, according to Hajjar (2004), a scholar who studies the relationship between religion, state power, and domestic violence in Muslim societies from Africa, Asia and the Middle East, information about domestic violence in those societies is limited due to resistance from Islamists.

\section{Status of Domestic Violence Worldwide}

The development of domestic violence policy in Europe. Europe has mixed experiences with domestic violence policy. In Northern Ireland during the 1990s, $40 \%$ of homicides and over $50 \%$ of all police reports were related to domestic violence, yet the police did not report cases of domestic violence (Taylor, 1995). Taylor (1995) explains that the politics of sectarianism from nationalist communities contributes to an environment of sexism and harassment in the Royal Ulster Constabulary (RUC). In England, police have been criticized for treating domestic violence less seriously than other crimes (Rowe, 2007). Recent research emphasizes the need to encourage victim participation during trial hearings and also to consider 
their preferred outcome (Lewis, 2004; Hague \& Mullender, 2006). Lewis (2004) argues that effective legal intervention should use traditional sanctions for short-term deterrence, coupled with long-term rehabilitation for men, and network support for women. On the other hand, the national policy in Finland and Scotland still has a narrow concept of domestic violence, emphasizing physical forms of violence and placing the onus on the victim (Hearn \& McKie, 2010).

The development of domestic violence policy in Asia. Research about domestic violence policy in Asia highlights problems of implementation related to its social and economic realities. India has a population of 1.2 billion. Roughly $25 \%$ of its population live below the poverty line (United Nations, 2006a, 2006b). The population of India has 353 million fewer women than men due to many reasons, including female infanticide, which is widely practiced (Vyas, 2006). Torture was the most predominant crime committed against women in 1995 in the country, corresponding to $30 \%$ of all reported crimes against women (United Nations, 2006a, 2006b). The first legal remedy criminalizing marital violence and dowry harassment was the Section of 498A, an amendment to the Indian Penal Code enacted through the Criminal Act No. 46 of 1983 (Vyas, 2006). In 2005 the Protection of Women from Domestic Violence Act (PWDVA) provided a broad concept of domestic violence and several other provisions, including protection order, residence order, monetary relief, custody order, compensation order, mandatory access to state medical facilities and shelter homes.

In Japan, approximately $15 \%$ of women have been physically victimized in cases of domestic violence, and in 200587 incidents of murder and attempted murder related this kind of violence were reported (WHO, 2005). Shahidullah and Derby (2009) observe that the first legal remedy in Japan, the Prevention of Spousal Violence and the Protection of Victims Act (Law 
No. 31), was enacted in 2001. This Law, however, did not criminalize domestic violence. Instead, it aimed at the provision of remedies for victims, such as notification, counseling, protection and welfare benefits, police protection, protection facilities, and protection orders of up to six months for more serious cases. The Law also included a penalty of not more than one year in prison and a fine of not more than one million yen (approximately nine thousand dollars) for violation of protection orders.

Bangladesh is among the countries with the highest index of domestic violence, where with $62 \%$ of women in rural areas and $53 \%$ of women living in urban areas have experienced physical or sexual violence (WHO, 2005). Yet, according to Shahidullah and Derby (2009), Bangladesh ratified CEDAW in 1984 and enacted two legal instruments, the 2000 Prevention and Repression of Women and Children Act, and the 2002 Acid Crime Control Act. These Acts prescribe the death penalty for several offenses, including rape or death caused by acid-throwing, and life imprisonment if the violence causes some type of permanent injury or disfiguration of face or head (Shahidullah \& Derby, 2009). According to Shahidullah and Derby (2009), acidthrowing is the most common type of violence inflicted against women in the country.

Describing the reality in Singapore, Narayanan (2005) provides one of the few studies in police decision-making in the Global South. The author argues that police subculture influences officers much more than any other situational factors, such as degree of injury or use of weapon. Using a cultural and attitudinal approach, the study targeted the normative values constructed through socialization in the police, and found that officers regarded domestic violence as a normal cultural practice. Ganapathy (2006) supports this position. One of the officers interviewed by the author shared that "it makes no difference whether you go to the scene [of a domestic violence case] in three or thirty minutes. You cannot do much (Ganapathy, 2006, p. 
188). Another interviewee argued that "in a domestic situation there is no wrong or right, guilty or innocent. Most of the time, I just have to depend on my conscience and experience to strike the right note with them" (Ganapathy, 2006, p. 184).

Narayanan (2005) lists other impediments to the implementation of domestic violence policy in Singapore. First, police are reluctant to criminalize domestic violence and show no interest in implementing structural changes. There are laws against domestic violence, but officers often use the Miscellaneous Offenses Act, typifying the crime as disorderly behavior, instead of physical injury under cases of family violence. Second, despite the existing laws, the concept of domestic violence is extremely narrow as eight conditions have to be met before it is classified as such, including the existence of permanent injury of a body part. Finally, the few cases that passed police scrutiny had a high withdrawal rate and officers blamed the victim for her unwillingness to substantiate allegations and assist with the prosecution (Narayanan, 2005).

The development of domestic violence policy in Africa. While Africa has had a long history of women's rights activism, as of 2008, only South Africa, Mauritius, Zimbabwe, and Ghana had domestic violence legislation (Ampofo, 2008). Ampofo (2008) provides a thorough examination of the status of domestic violence in Africa. The author presents Ghana's domestic violence policy as an example of collective activism where state and interest groups at times have conflicted but have been able to develop functioning law enforcement and legal structures. The author further explains that the African women's movement has framed domestic violence as an issue rooted in political, social, and economic inequalities consolidated through past colonization and current demands from corporate globalization. Thus, many movements in Africa have not sought to directly address issues of male-dominance, but rather challenge the exploitation and subordination of women in various spheres, including development policies. 
Examples of activism by women's movements in the region include the Aba Women's War against British taxation in Nigeria, the boycotting of women traders in Ghana, the mobilization against oil corporations in Nigeria's Delta region and the lobbying pro-gender politics organized by The Women's National Commission in post-apartheid South Africa (Steady, 2006).

Africa has the highest rates of domestic violence in the world (Rotimi, 2007). The World Health Organization estimates that $71 \%$ of women in Ethiopia and $56 \%$ in Tanzania have experienced physical or sexual violence from their partners (WHO, 2005). In Kenya, 47\% of all homicide cases in 2003 were related to domestic violence (Kimani, 2007). In Ghana approximately $33 \%$ of women have been physically injured by their current or former partners (Ardayfio-Schandorf, 2005).

Based on most African cultural beliefs, women are expected to be under the guardianship of a man (Shahidullah \& Derby, 2009) and wife-beating is considered an acceptable practice, not a crime (Ardayfio-Schandorf, 2005). Ghanaian domestic violence laws, first drafted by British jurists, allowed husbands to correct wives' alleged transgressions. As Ampofo (2008) notes, wives' refusal of husbands' sexual demands could be interpreted as transgression, since customary law guaranteed them "right" of sexual satisfaction. Moreover, husband's sexual demand could be used as grounds for divorce, leaving women in a state of complete financial burden and ostracized by the community.

A major uprising by women's organizations in Ghana during the early 1990s led to the creation of the Women and Juvenile Unit (WAJU) in 1998, currently named Domestic Violence and Victim Support Unit (DOVVSU). The Domestic Violence Act, passed in 2007, criminalized domestic violence under a broader definition, encompassing psychological and economic violence, and offered provisions for protective and restraining orders, mandatory arrest without 
warrant, specialized tribunals, and a fund for victims (Shahidullah \& Derby, 2009). The Ghanaian government also signed many of international human rights agreements and conventions. The Act and the DOVVSUs were considered some of the most important developments toward the criminalization of domestic violence. According to the Act, DOVVSUs should have social workers and psychologists, provide free and detailed information about the cases, refer victims to medical services, and develop educational preventive campaigns (Shahidullah \& Derby, 2009).

However, implementation in police stations and courts was much different than expected (Ampofo, 2008). DOVVSUs did not receive enough funds to provide all of the expected services and police officers were not trained. Many victims witnessed officers demanding bribes to report domestic violence incidents, being unfriendly and delaying investigations or poorly conducting them (Ampofo, 2008). The author further describes that court procedures remain time consuming, and the judiciary is heavily male dominated and patriarchal. Also, the courts ignored many cases on the basis that those cases were of private nature. As a Ghanaian judge opined, "it is un-Ghanaian for a man to be sentenced to imprisonment because he slapped or pushed his wife" (Ghanaian Chronicle, 2004.9, as cited in Ampofo, 2008). Unsurprisingly, victims were extremely frustrated with police and courts (Ampofo, 2008).

Recent developments in domestic violence policy in the Americas. Current studies from United States and Canada show concerns about police response, arrest rates, the paucity of prosecution, and the role of victim participation in the implementation of domestic violence (Dawson \& Dinovitzer, 2001; Garner \& Maxwell, 2009). Garner and Maxwell (2009) compared the prosecution and conviction rates in the United States with those in Australia, Canada, Switzerland, and the United Kingdom. In particular, these two authors found that United States 
scored lower in all rates: prosecution per offense was $27.6 \%$, compared to $45.5 \%$; conviction per reported offense was $14.4 \%$, compared to $17.6 \%$; and conviction per prosecution was $49.9 \%$, compared to $53.8 \%$ in other countries. However, the rate of prosecution per arrest was higher in the United States, 61.6\%, in comparison to 50.7\% in other countries (Garner \& Maxwell, 2009). Studies on the predictors of prosecution in Canada revealed that when a victim is perceived to be cooperative, likelihood of prosecution increases seven times (Dawson \& Dinovitzer, 2001). These results are similar to the findings presented early in this chapter about factors influencing a prosecutor's decision-making in the United States. Regarding judicial decision-making in Canada, Crocker (2005) examined written judicial opinions of 252 cases reported during the years of 1970 and 2000. The author performed a content analysis to identify how the language used in the decisions reflected judicial views. The analysis revealed that the language changed overtime and judges were more aware of domestic violence cases. However, there was evidence of paternalism, with judges often making remarks that reflected stereotypes regarding the role of women (Crocker, 2005).

Domestic violence policy scenario is much different in the Caribbean and Central America. As of January 2012, Haiti did not have any legislation criminalizing domestic violence (Human Rights Watch, 2012). According to the Human Rights Watch (2012), Haiti is the poorest country of the Western Hemisphere and the situation became worse after the 2010 earthquake which killed about 220,000 deaths and made thousands refugees. There are many accounts of female refugees suffering physical and sexual violence at refugee camps (Human Rights Watch, 2012).

Trinidad and Tobago passed The Domestic Violence Act in 1991 but lacked financial support to implement the policy. According to Lazarus-Black (2001), many victims in extreme 
poverty withdrew their cases because they could not afford going to court, were economically dependent on their partners, feared lack of family support for children, or were intimidated by the husband's family, as well as by their own family. Court proceedings were delayed while lawyers, court staff, and judges assumed that most women claiming to be victims of domestic violence had ulterior motives or had other disputes with their husbands, such as property claims.

Other Latin American countries have had a similar trajectory with regards to the development of domestic violence policy, many of them influenced by Brazil, since they share political history and background. Many countries broke away from military authoritarianism during the 1970s (Mauleón, 1998) and during the 1980s, entered a new period of social and political awareness that laid the foundation for legal and law enforcement institutional reforms during the 1990s (Larrain, 1997). Major international events and organizations saw an opportunity to push for the inclusion of women's rights issues in reform agendas of many countries. In particular, The 1996 Cartagena event, Colombia Encuentro, played a vital role in the sharing of problems and goals of feminist movement in Latin America (Mauleón, 1998). The establishment of Inter-American Commission on Women and its crucial role in the creation and adoption of the Declaration on the Eradication of Violence Against Women in 1994 also helped advance the recognition of domestic violence in Latin America.

Throughout the 1990s, domestic violence policy was framed in different ways, from women and human rights issues to health and economic issues. The Pan American Health Organization, especially with support from banking institutions, studied the impact of domestic violence on economic development in many Latin American Countries. Such studies had found that health costs related to domestic violence average between five $24 \%$ of the GDP per year, 
and the wage loss of women workers is equivalent to almost two percent of the GPD (Hawkings \& Humes, 2002).

As alluded to above, many Latin-American countries have followed the Brazilian model of domestic violence policy. For example, countries such as Ecuador, Nicaragua, Peru, and El Salvador have created specialized police units, passed laws, and adopted a more humanitarian approach (Tamayo, 1998; Torres, Ileana, \& Cuadra, 2000). Ecuador in particular passed a law in 1995 to address violence against women and created Women and Family Police Stations (las Comisarías de la Mujer y la Familia) (Tamayo, 1998). Nicaragua established Women's and Children's Police Stations (the Comisarías de la Mujer y la Niñez), although in some cases officers were applying extra-judicial arrangements as an alternative to making arrests in majority of cases (Centro Nicaragüense de Derechos Humanos, 1995; Torres, Ileana, \& Cuadra, 2000). Similarly, Peru established Women's Police Stations and Specialized Delegations (Delegaciones Policiales de Mujeres y Secciones Especializadas), albeit the rate of convictions did not increase and officers mainly opted for mediation as their preferred method of addressing domestic violence (Tamayo, 2000). While El Salvador took steps to implement the Brazilian model, a study about gender discrimination within the Salvadoran Civilian Police revealed that $64 \%$ of female officers had experienced gender discrimination. Although 54\% had been a victim of violence at the hands of their coworkers, only $32 \%$ had filed a formal complaint (Flores, 2000). As noted in the introduction chapter, Brazil first adopted the American law enforcement approach toward cases of domestic violence (Shahidullah \& Derby, 2009), but later switched to the broader human rights perspective due to influence by international organizations (Erwin, 2006). The birth of domestic violence policy was first marked by the creation of Women's Police Stations in 1985 (Santos, 2005). Later the policy shifted away from the law enforcement 
approach toward a more holistic approach, whereby a greater emphasis was placed on the provision of integrated services, where victims were provided access to legal and psychological counseling, and granted protection orders. This change of approach was influenced by international interest groups and advocates, who charged the Brazilian police and judiciary with neglect and human rights violation at the Inter-American Commission on Human Rights (Santos, 2005). Shocking evidence of neglect and mishandling of domestic violence cases reflected how poorly the policy was being implemented. For example, advocates presented the case of Maria da Penha, a woman who became paraplegic after her husband shot her in the spine while she slept. After 20 years of case proceedings, the husband was sentenced to two years of probation (Santos, 2005). This sentence was in accordance with how domestic violence was traditionally treated in country: as a misdemeanor and regulated under the law 9099/95, which provided alternative penalties and up to two years of incarceration (WHO, 2006).

It was not until the year 2006 that the Brazilian government enacted the federal law No. 11.340, currently known as Law Maria da Penha. The law criminalized multiple forms of domestic violence, established provisions for the creation of more police stations and specialized courts, established strategies, models, training, and practices to be adopted by criminal justice professionals (“Observe: Observatório da Lei Maria da Penha,” 2010). With the enactment of this law, there has been an increased societal awareness across the country, mainly due to wide media coverage (Santos, 2005). This awareness has reached Espírito Santo, the state with the highest rate of domestic violence in the country (Meneghel \& Hirakata, 2011). The state has a rate of 9.4 for every 100,000 women, which is more than double the national average (Waiselfisz, 2012). Half of the 171 women murdered in the state in 2010 were victims of domestic violence (Waiselfisz, 2012). 
Meneghel and Hirakata (2011) have identified factors accounting for Espírito Santo’s high rate of female homicide. Based on a national study, the authors found that the female homicide is directly related to urban violence. This finding suggests that violence against women is more likely to occur in urban areas, where women are more likely to have higher levels of education, to be employed, to become economically independent, and have less children. As traditional gender norms are challenged, unemployed men who fear losing the role of breadwinner and head of the family are more likely to react aggressively. This scenario is predominantly evident in growing urban areas such as Vitória, ES. The study however found no correlation between poverty and female homicide. Indeed, regions with high levels of poverty, fecundity and natality tend to have crystalized gender roles, meaning that women are less likely to report domestic violence and be in a situation of conflict that results in their killing. Urban areas, on the other hand, face greater social and economic inequalities. In a context where governments fail to provide safety and access to justice, the insurgence of drug trafficking, mass killing, and lack of accountability are likely to occur (Minayo, 1994).

Given these stark statistics and the inadequacy of academic literature on this issues in Brazil, this study advances a social-scientific investigation of legal and extra-legal factors influencing the decision-making of police and courts in country and Espírito Santo. The lack of research on the issue of domestic violence might be due to the prevailing assumptions within legal scholarship in the Brazil that government officials are solely influenced by law. Yet, this work, which is based on court community studies, has provided solid evidence that debunks the legal metaphor and associated legalistic discourse. As this study demonstrates below, stakeholders involved in the implementation of domestic violence are influenced by "non-legal" factors. Thus, the next section explores the implementation of the policy in Brazil. 


\section{Conclusion}

The development of modern US domestic violence policy can be dated to around the 1970s. The development of the policy occurred due to pressure on the US government from the women's rights movement in the country. Through the establishment of shelters and clinics for victims of domestic violence and forums of discussion, the movement engaged in legal mobilization that brought major change in the US legal frameworks, as well as those other countries in the world.

During the 1970 s cases of domestic violence gained more visibility as a legal, political, and social issue in the United States. It is during this period that the government started regulating issues of public morality and other social problems. During the same time, police had adopted mediation as the standard approach in domestic violence cases. The Michigan police, for example, trained officers to avoid arrest whenever possible. Other academies trained officers in conciliation and conflict management skills to be used in the newly created units of family crisis intervention. This approach would have been the standard if it were not for the 1977 class action where battered women sued the New York Police Department for denial of protection due its failure to arrest batterers.

By the 1980s, several states had started issuing protection orders and recognizing spousal rape as a crime. Most importantly, the majority of the states adopted pro-arrest or mandatory arrest policies, as a result of the Supreme Court decision that held that police failed to provide equal protection under the law when they failed to arrest batterers. In the 1990s, the federal government enacted the Violence Against Women Act (VAWA), which further brought more changes to the policy. VAWA reinforced the adoption of mandatory arrest policy throughout country and spurred the development of new mechanisms to extend protection and eligibility of 
victims. For example, it extended eligibility to file charges to unmarried and same sex couples, cohabitants or not, or in a dating relationship, and allowed officers to arrest if there was a reasonable cause to believe that a felony, misdemeanor, or violation of restraining orders had occurred. It also secured the provision of state funds and the establishment of a standard system of protocols, forms, and reports.

These and other measures are still used today as strategies to prevent and address domestic violence. The concept of domestic violence is applied broadly, including physical injury, sexual assault, threats of violence and intimidation, property destruction, stalking, and any other forms of harassment. There is also provision of emergency protection orders, expedited trials, training to hinder bias of police officers and criminal justice professionals, services to victims and batterers, including psychological counseling and welfare support.

One of the most remarkable developments in the US Domestic Violence Policy was the creation of specialized domestic violence courts. These courts further developed a restorative or therapeutic justice model and promoted the use of coordinated approaches that placed greater focus on the needs of victims and perpetrators, promoted a positive impact in society, and allowed for better communication between courts, police, civil and criminal spheres.

Several interest groups and international networks pushed for the internationalization of the US domestic violence policy. Many countries developed policing and litigation responses similar to the ones adopted in the United States, issuing police statutes and making attempts to enforce criminal punishments for domestic violence offenses. Examples of such countries include Albania, Armenia, Bulgaria, Poland, Macedonia, Moldova, Nepal, Romania, Ukraine, Uzbekistan, Puerto Rico, and Brazil. Soon after many of these countries began implementing their US-modeled legalistic approach to domestic violence, the implementation became 
problematic due to multiple factors, including lack of structural support provided to victims, concerns about police integrity, and influence of cultural issues.

In the meantime, the United Nations, one of the most influential international bodies shaping the internationalization of domestic violence policy, pushed for a human rights approach. The United States used an individualized, legalistic approach, which was rooted more on the achievement of civil and political, mainly first generation rights. Therefore, domestic violence was framed as an individual issue, to be solved at the criminal justice system because women's rights were infringed. The United Nations, on the other hand, framed domestic violence as a broader human rights issue that required the consideration of victim's economic, social and developmental living standards. In this sense, measures to address domestic violence must use a collective approach, applied through integrated solutions that address aspects of safety and punishment, and also advance the sustainability and affirmation of first, second and third generation rights, respectively, related to individual, economic, social, and developmental rights.

Like in other countries in the developing world, the Brazilian government initially adopted the US approach, but later embraced the human rights perspective. This perspective was strongly endorsed by the United Nations Declaration on the Elimination of Violence Against Women. As such, the criminalization of domestic violence in Brazil and the enactment of a detailed domestic violence legislation was influenced by international interest groups and advocates. The development of the Brazilian domestic violence policy is comprehensively detailed in the second chapter. 


\section{Chapter 2: Domestic Violence Policy in Brazil: An Overview}

The rise of women's movements on the international stage during the last four decades has influenced the development of national domestic violence initiatives in Brazil (Rifiotis, 2001, 2004). The onset of movements in 1970s in particular coincided with Brazil's transition from dictatorship into democracy. The transition allowed space for political discussions about existing forms of oppression in the country (Cortez \& de Souza, 2008). The women's movement in Brazil strategically developed partnerships with various international organizations and put in place forums of discussion about the status of women in the society and $t$ pushed for criminalization of all acts of violence against women (Wolfe, 1993; Waylen, 1996; 2002). Up until then, cases of wife murder were absolved under the legal provision of honor killing, those of injury dismissed, and cases of rape not considered because no legal provision for marital rape existed (Jaquette, 1994).

Three groundbreaking events marked the development of domestic violence policy in the country: the creation of the first specialized police unit in 1985, the enactment of the law 9099 in 1995, and the passing of the law 11.340 in 2006. Known as Maria da Penha law, the law 11.340 increased the jurisdiction of specialized police units, established the creation of specialized courts, and guaranteed an array of services in support of victims of domestic violence (Pasinato, 2010). Despite the enactment of the law, today, the reality of how police stations and courts deal with domestic violence is far from the intent of the legislators. Institutions are underfunded, understaffed, and lack the minimum structure to operate adequately ("Observe: Observatório da Lei Maria da Penha," 2011). For example, the staff are mostly overwhelmed with high number of cases and have scarce resources such as computers, desks, and chairs. 
This chapter discusses the development of Domestic Violence policy in Brazil. After a brief overview of the country's political and legal structures, the chapter presents the historical unfolding of the domestic violence policy beginning in the 1980s. The second part of the chapter addresses the prevailing perceptions about the implementation of the new policy in the state of Espírito Santo.

\section{Brazilian Political and Legal Structures}

Brazil is a federal republic composed of 5,564 municipalities, 26 states, and a federal district. The states are divided in five regions: north region, northeast region, central-west region, south region, and southeast region. Espírito Santo is located in the latter. According to the 1988 constitution, the federal government is divided into three branches: the executive, judiciary, and the legislative. The executive and legislative at the municipal, state, and federal levels are independent. Members of the executive and legislative branches at all levels are directly elected.

\begin{tabular}{|c|c|c|c|}
\hline & Executive & Legislative & Judiciary \\
\hline Federal & $\begin{array}{l}\text { The President is } \\
\text { responsible for } \\
\text { implementing and } \\
\text { enforcing the laws at the } \\
\text { national level. }\end{array}$ & $\begin{array}{l}\text { The Congress (Congresso) } \\
\text { is formed by the House of } \\
\text { Representatives (Câmara } \\
\text { dos Deputados) and the } \\
\text { Senate (Senado Federal). } \\
\text { It has the power to enact } \\
\text { legislation and initiate } \\
\text { revenue bills. }\end{array}$ & $\begin{array}{l}\text { Federal courts interpret the } \\
\text { law, determine the } \\
\text { constitutionality and apply } \\
\text { them to individual cases. The } \\
\text { Supreme Federal Court } \\
\text { (Supremo Tribunal Federal) is } \\
\text { the highest court. }\end{array}$ \\
\hline $\begin{array}{l}\text { State } \\
\text { Government }\end{array}$ & Headed by a governor. & $\begin{array}{l}\text { TheAssembly (Assembléia } \\
\text { Legislativa) is composed of } \\
\text { elected state representatives } \\
\text { (Deputadas e Deputados } \\
\text { Estaduais). }\end{array}$ & $\begin{array}{l}\text { State judicial branches are led } \\
\text { by the state supreme court } \\
\text { (Tribunal de Justiça), which } \\
\text { hears appeals from lower-level } \\
\text { state courts. There are also } \\
\text { federal state courts. }\end{array}$ \\
\hline $\begin{array}{l}\text { Local } \\
\text { Government }\end{array}$ & $\begin{array}{l}\text { Headed by a mayor in a } \\
\text { Municipal government, } \\
\text { municipalities or districts } \\
\text { (townships). }\end{array}$ & $\begin{array}{l}\text { The City council (Câmara } \\
\text { Municipal) is composed of } \\
\text { elected representatives } \\
\text { (Vereadores). }\end{array}$ & $\begin{array}{l}\text { There is no judiciary branch at } \\
\text { the local level, although judges, } \\
\text { public defenders and } \\
\text { prosecutors might be assigned } \\
\text { to work with local authorities } \\
\text { (at Comarcas). }\end{array}$ \\
\hline
\end{tabular}

Table 1: Members of the Brazilian Executive, Legislative, and Judiciary at the federal, state, and local levels. 
As shown in Table 1, the judiciary branch operates at the federal and state levels only. Judges and other law officials are required to take competitive entry exams in order to be appointed. Brazilian law is codified and follows the civil law system, reflecting the influence from German and Italian legal systems. Furthermore, the law is divided into various legal codes, ranging in focus from commercial, civil, criminal, and family to international specializations. As spelled out in the constitution, court decisions are jurisprudence, working as guidelines for future decisions. However, uniformity is not expected among the regions. Legal decisions in municipalities and states must be in line with the Federal Constitution. As such, while the law is the same for the entire country, regional divergence in the interpretation and decisions is expected. The Supreme Federal Court is the highest Court and thus decides all cases that come under its consideration.

Police in Brazil. Law enforcement in Brazil is divided among three main institutions: the Federal Police (Polícia Federal), the State Military Police (Polícia Militar) and Fire Brigade (Bombeiros), and the State Civil Police (Polícia Civil). The federal constitution defines the jurisdiction of each law enforcement agency. The Federal Police are affiliated with the executive branch of the Federal Government, while the other two are affiliated with state governments. The federal police deal with criminal offences committed against federal institutions while the military force is responsible for the crime prevention and maintenance of public order, such as patrolling and answering emergency calls. They are also responsible for answering domestic violence calls and directing suspects and victims to file reports through the civil police. The civil police are responsible for crime investigation and forensics. In domestic violence crimes, they file complaints, gather evidence, and refer cases to the judiciary. In this study, we focus on the work, and its dynamics, of the civil police. 
Typically, there is at least one civil police unit in each city consisting of police authority, agents, investigators, and inspectors. All police positions are appointed through competitive selection process that includes intellectual, physical and psychological examination of candidates. Candidates for the position of commissioners and notaries must have a law degree to be eligible for the said position (Jubb \& Izumino, 2003; Roure, 2009). The main functions of the civil police are stipulated in the constitution, as they pertain to investigation, planning, execution and control of functions of judiciary police, as well as the investigation of penal infractions, with the exception of those under the jurisdiction of the military police. As Brazil transitioned to democracy, the Federal Government established a project of modernization of the police, expanding its role as an educator. For example the police began giving presentations at public schools and community centers. In the context of domestic violence, Maria da Penha law added to the modernization of police by assigning new roles and responsibilities for the women's police stations. Among the responsibilities, the police must engage in preventive and investigative measures in all cases where women are victims of any form of crime beyond those defined as domestic violence crimes.

Brazilian judicial system. The Brazilian Federal Constitution divides the Brazilian court system into Military Courts, Labor Courts, Electoral Courts, Federal Ordinary Courts, and State Ordinary Courts. Federal Courts deal with issues related to the Federal Government, including political crimes, crimes committed aboard ships or aircraft, crimes involving foreigners or foreign governments, and indigenous people. The functions of State Ordinary Courts, or trial courts, are divided by specialization, such as based on the type of the subject under consideration, just as is the case with specialized courts on domestic violence. Across the country, the judicial districts have at least one trial court where a judge alone decides on civil 
cases and most of criminal cases. A jury presides in hearings on crimes against life, such as manslaughter, infanticide, abortion, and the instigation for one to commit suicide. Appeals of Trial Court's decisions are sent to the State Court of Justice, where three judges can review any decision and give the final word on decisions at state level. The system is however still dominated by the Supreme Federal Court, which analyzes the constitutionality of federal or state laws or statutes, and the Superior Court of Justice, the Brazilian highest court for nonconstitutional issues. The decision regarding the constitutionality of Maria da Penha law was decided by the Supreme Federal Court (Supremo Tribunal Federal), which worked together with the National Justice Council (Conselho Nacional de Justiça), to coordinate joint actions between the courts in regards to the decision-making of domestic violence cases.

Civil law judges are the leeway to decide based upon their own interpretation of the law and not be pressured to follow any precedents. In order to become a civil law judge, law school graduates are evaluated in many areas and must pass a series of tests, including written and oral exams, and must demonstrate proof of related professional experience and mastery of legal principles and philosophies. Given this merit-based selective process, the pool of Brazilian judges is more diverse and less politically involved than American judges (Cochran \& Cavazotte, 2009). However, judges are playing an increasing role in the policy-making process (Taylor, 2008).

Brazilian criminal law distinguishes public crimes and private ones. Public crimes are understood to be those committed against society as a whole. Therefore a prosecutor is mandated to file criminal charges under the jurisdiction of the State Attorney General. In private criminal acts, only the victim can file a complaint. Examples of these crimes include statutory rape, insults, defamation, threats, and violent attacks intended to shame. In order to gain prosecution 
for violence committed against them, victims have to file claims at the police station and wait upon investigation by the police.

\section{Domestic Violence in Brazil before the 1980s}

Brazilian colonial laws allowed men to physically punish women. Brazil was a colony of Portugal until September 7, 1822. Portuguese laws dismissed cases of honor defense killings where woman and her lover were the only victims (Thomas, 1992; Hermann \& Barsted, 1995; Santos, 2008). Soon after independence, the Brazilian Criminal Code of 1830 prescribed that such crimes were subject to prosecution, albeit punishment could be reduced if it were found that the woman had committed adultery (Blay, 2003). Following independence, Brazil adopted a civil law system and unified its legislation for the entire country (Santos, 2005). This means that the defense of honor was considered legitimate self-defense in cases of wife-murders across the country (Besse, 1989; Santos, 2007). Additionally, it meant that cases of domestic violence would remain distant from the eyes of the Brazilian police and courts for a long time. It wasn't until the mid-1970s, during a period of tremendous political pressure and dictatorship, that the Brazilian women's movement was able to challenge assumptions about domestic violence (Ardaillon \& Debert, 1987; Hermann \& Barsted, 1995; Almeida, 1998; Santos, 2008). A coup d'état in 1964 marked the beginning of the authoritarian military dictatorship that lasted until the mid-1980s. The regime was led by the Armed Forces which had overthrown a democratically elected government with United States financial support. During this period, several atrocities were committed across the country to repress any resistance. Thousands people were removed from office, detained without trial, tortured, raped, castrated, or killed. Particularly, university professors were a major target of kidnaps or went to exile. During this period, feminist activist 
groups provided considerable amount of service to women, youth, and children in various situations of violence (Alvarez, 2000; Diniz, 2006).

The chaotic political situation provided a fertile ground for expansion of feminist movement in Brazil. In the course of providing services, activist groups learned about the realities of women and their interactions with police. In addition, activists were able to develop political strategies to use with the advent of democratization. One of these groups, the 'SOS Mulher', emerged in São Paulo during the 1980s with an intention of raising consciousness about domestic violence, and bringing about change at police stations through training of police officers (Diniz, 2006). Branches of SOS Mulher were also established in Rio de Janeiro and Belo Horizonte. Coalitions with political parties granted these groups better involvement in local government matters, culminating with the creation of state councils, the Conselho Estadual da Condição Feminina in São Paulo, and the Centro de Defesa da Mulher in Belo Horizonte (Pinto, 2003; Diniz, 2006; Santos, 2008). The goals of these organizations included pushing for criminalization of domestic violence and providing preventive measures such as educational campaigns, shelters, legal and psychological support centers, incentive to research about violence against women, training of police force, and expansion of police force with the recruitment of social workers (Santos, 2008). The idea here was to establish an integrated system that enhanced the coordination between feminist groups and the government (Grossi, 1988; Gregori, 1993).

Unfortunately, it did not take long before these ambitious plans began to fail. Firstly, the center for legal and psychological counseling services (Centro de Orientação Jurídica e Encaminhamento a Mulher - COJE), created in 1984, received no government funding most of its staff were volunteers, and it thus had to close its doors (Santos, 2005). Secondly, while the São Paulo State Council on Women's Concerns (Conselho Estadual da Condição Feminina) 
shared its agenda with Michel Temer, the state's secretary for public safety, he was not supportive of the idea of collaborative partnership. Instead, he claimed solo responsibility for the establishment of what he considered to be the world's first women's police station (Hautzinger, 2007).

\section{The 1980s: Creation of the Brazilian First Women's Police Station}

It is believed that local and international forces influenced the creation of the first women's police station in Brazil in the 1980s. In São Paulo, feminist groups lobbied politicians to consider women's rights issues in the agenda (Santos, 2005). The number one item in the agenda of the Council on Women's Concern was eradicating domestic violence. Framing domestic violence as a social and structural problem rooted in machismo culture, the Council intended to show how poorly women victims of domestic violence were treated at police stations (Goldberg, 1985). One of the several senior government individuals from whom the advocates sought help to implement their agenda was Temer (Santos, 2005).

Meanwhile, the Brazilian federal government signed the United Nations Convention on the Elimination of All Forms of Discrimination Against Women (CEDAW) in 1984. With the signing on CEDAW, the government expressed its interest in demonstrating accountability over many issues faced by Brazilian women (Santos, 2005). Yet, the president had reservations about taking measures to address issues related to women's job status, employment, voting rights, and inheritance (Santos, 2005). One of the outcomes of these concerns about women issues was the creation of National Council for Women's Rights in 1985, the Conselho Nacional dos Direitos das Mulheres, composed of members of civil society and government representatives (Pitanguy, 1990; Macaulay, 2006; Santos, 2008). Another outcome was Temer's idea to create a police 
station staffed by women to handle cases involving crimes committed against women (Ardaillon, 1989; Alvarez, 1990).

Under wide media coverage, São Paulo governor Franco Montoro signed the decree 23.769 in August of 1985, creating the first women's police station in Brazil and in Latin America. Although some claimed that Brazil established the first women's police station in the world, Hautzinger (2007) clarified that India had established women's police station earlier in 1973. This political act brought several consequences to the development of domestic violence policy in the country. First, it determined that the police station should serve female clients only. Second, it framed domestic violence as a criminal issue (Santos, 2005). Third, it undermined the participation of feminist advocates in the policy development and implementation.

The creation of the women's police stations wasn't necessarily an idea from advocates of the women's movements, despite their harsh critiques of how police treated women in police stations. According to Santos (2005), feminist advocates developed strategies nationally and internationally in order to bring visibility to the issue of domestic violence in Brazil. The State, on the other hand, embraced and translated the demands of feminist advocates. To this end, the state focused on the criminal aspects of domestic violence. This focus ultimately affected the feminist agenda and framed the way the state respond to domestic violence incidences. It brought new meaning to the context of violence and shone light on how female victims were treated by the system. In other words, the violence was trivialized. Thus, the state not only neglected the demands of feminist interest groups, but also showed how indifferent it was to broader claims expressed in the feminist agenda (Santos, 2005).

Over the years, there were several engagements between the government and the feminist movement. While the government attempted to regain political support from feminist groups, 
feminists wished to participate in the training of police force (Santos, 2010). Feminists soon realized that policewomen were also mistreating victims of domestic violence. In fact, the majority of the policewomen assigned to women's police stations did not want to work there. The police women were an outcome of an influx of female officers recruited when the police started admitting them beginning in the 1980s (Htun \& Power, 2006). Many of the recruits were assigned secretarial jobs, despite undergoing the same evaluation as male colleagues and obtaining higher scores them (Htun \& Power, 2006; Roure, 2009). Indeed, the establishment of women's police stations was faced with contradictions that imperiled their intended role in the implementation of domestic violence policy. On one hand, decision-makers believed that women's police stations would ultimately create a new sphere of power in the police force where talented women could finally achieve their full potential (Roure, 2009). On the other hand, policewomen considered those stations a career trap, a place where they were not doing real professional police work (Pougy, 2010).

Another crucial debate involved a discussion of the types of crimes that would be fall under the jurisdiction of the women's police stations. Initially, the Chief of Police allocated only sexual crimes, like rape and harassment, to these police stations. Feminist activists pushed for the inclusion of crimes of homicide and physical injury claims, which the Chief of Police denied at first. After victims filed several reports of physical injury at the first police station, the government expanded the jurisdiction of other police stations. However, homicides were to remain under the jurisdiction of the division of homicides, and still are to day (Santos, 2010). The São Paulo governor, Franco Montoro, who remained in power until 1987, established 13 more specialized stations in the state. Soon after assuming office, his successors realized the popularity of the women's police stations and took great effort to increase the numbers of 
stations around the state. In particular, governor Orestes Quercia created 45 stations between 1987 and 1990. Governor Luiz Fleury established another 58 stations between 1990 and 1994. However, none of these stations had ties with feminist groups, and none of the officers working there received training (Santos, 2010). About $70 \%$ of all police stations in the country before 2010 were created between 1985 and 1989 (Sardenbeng, Gomes, \& Tavares, 2010).

\section{The 1990s: Enactment of Law 9099/1995}

Systematic changes in police and courts during the 1990s further impacted domestic violence policy. By the 1990s, women's police stations were already overwhelmed with high volume of cases. For example, three police stations in Rio de Janeiro, combined, registered 2,250 reports in 1990. Two more stations were created in 1992 and the combined number of cases registered increased to 6,460 during the same year (Barsted, 1994). Although Brazilian Criminal Law prescribed penalties for physical injury, threats, and crimes of similar nature, police officers usually avoided filing reports and instead attempted to conciliate victims with their batterers (Izumino, 2003). Izumino (2003) estimated that during the 1990 s over $70 \%$ of the cases were archived for lack of victim's interest.

In 1995, the Law 9099 created specialized civil and criminal misdemeanor courts. At the time, the Courts were going through a process of judicial reform, resulting in the creation of several specialized courts aimed at reducing the load at regular courts (Izumino, 2003). The reform helped reduce the costs and cut down the number of court staff, and marked a transition to a neoliberal ideology as the government became less interested in punishing individuals (Diniz, 2006; Santos, 2008). According to the new paradigm, the state needed to expedite traffic or misdemeanor cases in the judiciary by encouraging conciliation between the parties. According to Aquino (2008), the Law 9099/95 was not only meant to conciliate the parties, but 
also to clean records of the aggressors. Accordingly, specialized civil courts were to hear civil cases where a dispute was assigned a value of up to 40 monthly wages based on the minimum wage. Moreover, parties could file a complaint without a lawyer if the case was estimated to be less than 20 monthly wages. In both cases the hearings were first scheduled with a mediator, a government official who would seek to identify a common ground between the parties. In misdemeanor criminal courts, defendants were usually sentenced to provide food baskets to charity, pay fines or financial compensations, or engage in community service (Roure, 2009). Food baskets (Cesta básica) are an assortments of basic groceries including sugar, rice, beans, and flour packed in a single bag or box in a supermarket, costing around $\$ 100$ and which are targeted to low income Brazilians.

It seems that policymakers did not expect that these courts would receive massive influx of domestic violence cases from women's police stations (Barsted, 2007; Santos, 2008). According to the Brazilian Criminal Code, threats and physical injuries of first degree are considered misdemeanors, since their prescribed punishment is less than two years of incarceration. Coincidently, these crimes represented the majority of the reports at the specialized police stations (Conselho Nacional dos Direitos da Mulher, 2001). This unexpected outcome generated a public debate, marked by opposing views, about the presence of domestic violence cases in misdemeanor criminal courts. On one hand, some argued that Law 9099/95 brought visibility to the status of domestic violence in the country (Izumino, 2003; Oliveira, 2008), especially since the Law required that less than $30 \%$ of cases not retrieved by mediation at police stations be granted a formalized process in the judiciary (Izumino, 1998; Campos, 2003). On the other hand, others argued that the conciliatory ideology behind these courts was likely to victimize women a second time, since officials and judges were required to ask victims 
to forgive the perpetrator (Campos, 2003). Although the Law 9099/95 offered the victim an opportunity to be financially compensated, it is very likely that victims were more interested in being guaranteed safety, ensuring that violence against them would stop. In fact, several claims were archived once the aggressor promised to cease harming their victim.

While some considered police and courts a space where women were being empowered, others viewed them as an arena of decriminalization, privatization, and trivialization of domestic violence (Debert, 2006). This concern stemmed from an observation that the said police and courts often dismissed domestic violence crimes and failed to conduct public investigation, reinforcing an old myth that domestic violence was private issue unworthy to be considered (Izumino, 2003; Debert, 2006). Due to the process of judicialization, interpersonal conflicts were framed under the polarity plaintiff-defendant (Rifiotis, 2004). In the name of celerity and informality, judges ignored the history and family ties that existed between the parties, neglected the high likelihood of recidivism, and reinforced the culture of silence by denying victims the right to be respected, considered, recognized, and validated (Rifiotis, 2004; Izumino, 2003).

Furthermore, the Law 9099/95 caused a new intense debate about the role of the women's police station in domestic violence policy. Police stations were seen as gateway for victims to seek access to the courts. Police officers were viewed as gatekeepers, responsible for deciding how many cases would go to the judiciary. Over the years, several other states started establishing women's police stations (Santos, 2010). As most of the stations were established without the participation of feminist groups, the ties between advocates and the government became weaker (Gregori, 2006). As a result, funding for the feminist national council was terminated during the administration of President Fernando Collor de Melo (1990-1992) (Macaulay, 2006). The succeeding presidents Itamar Franco (1992-1993) and Fernando Henrique 
Cardoso (1995-1998 and 1992-2002), did little to advance feminist goals , despite receiving many letters from the feminist movement while, at the same time, claiming attention to women's issues at national and international level (Macaulay, 2006).

As pointed out earlier, the 1993 World Conference on Human's Rights, specifically, was a landmark for the recognition of women's rights worldwide. In the following year, the Organization of American States (OAS) had its fourth regular session of the General Assembly in Belém do Pará, Brazil on June 9, 1994 at the $24^{\text {th }}$ regular session of the General Assembly to the OAS. During the session, the OAS approved the Convention on the Elimination, Prevention, Punition and Eradication of all types of Violence against Women, pressuring several other Latin American countries, including Brazil, to be a signatory. Cardoso then incorporated the international human rights norms into the body of Brazilian legal system, ratifying both the American Convention on Human Rights and the Belem do Pará Convention (Santos, 2007).

These ratifications yielded two important outcomes in the history of domestic violence policy in Brazil. First, violence against women was framed as a violation of human rights. Second, feminist and human rights organizations had full legitimacy to engage in transnational legal mobilization and draw international attention on national cases (Santos, 2007). It did not take long for advocates to share Maria da Penha's case with international bodies. This move drastically changed the dynamics of Domestic Violence Policy in Brazil.

\section{Case Maria da Penha Maia Fernandes and the enactment of Law 11.340/2006}

On May 29 1983, Marco Antonio Heredias Viveiros, a university professor, tried to kill his 38 years old wife, Maria da Penha Maia Fernandes, a pharmacist, at her home in Fortaleza, Ceará State. He pulled his gun and aimed at her back while she slept. Maria was wounded in the spine and became paraplegic. Two weeks later, he took another attempt to kill her while she was 
in the shower. He tried to electrocute and drown her. These acts of violence were a sad highlight of a series of many acts of aggression he committed against her throughout their marriage. Maria da Penha had sought help at local police station, but nothing was done other than the registration of the case in the police reports. Although the prosecution acknowledged that violence against Maria was a case of attempt of murder, her husband's several appeals granted him freedom while the case was still decided.

In 1996, several non-governmental organizations joined forces to bring her case to the attention of the Inter-American Convention to Prevent, Sanction, and Eradicate Violence against Women, the Belem do Pará Convention. Some of the organizations included the Latin-American and Caribbean Committee on Women's Rights (Comitê Latino-Americano e do Caribe pela Defesa dos Direitos da Mulher-CLADEM) and the Center for Justice and Internal Law (Centro Pela Justiça e o Direito Internacional-CEJIL). In April 2001, the Belem do Pará Convention published a report indicating that the Brazilian government had violated Maria da Penha's rights to due legal process. Moreover, it highlighted that her case as evidence of a pattern of discrimination and neglect towards cases of violence against women in Brazil. Ultimately, the Convention demanded the government take urgent measures to address such cases. Maria da Penha's case was finally terminated in March 2002 when Marco Antonio was arrested r, almost 20 years after she filed charges. Marco Antonio was sentenced to just over six years, but he served only two and remained free thereafter (Santos, 2005).

It was during the administration of president Luiz Inácio Lula da Silva (2003-2010) that government started reestablishing ties with feminist groups (Santos, 2010). President Lula created an office responsible for development of policies focusing on women's rights, the Secretaria Especial de Politicas para Mulheres (SPM). One of the first actions taken by the 
office at the time was a presentation about the status of domestic violence policy at a meeting with representatives from the Belem do Pará Convention in June of 2003. A month later, in its $29^{\text {th }}$ meeting, the Convention recommended that the Brazilian government immediately enact and implement a law to address cases of domestic violence. In March of 2004, the government established a group, the Grupo de Trabalho Interministerial, to formulate the law (Barsted, 2006). Under broad media coverage, the president signed the Law 11.340 in 2006, baptizing it Maria da Penha Law.

Changes brought by Maria da Penha law had a direct impact on the power of discretion of police officers, prosecutors, and judges. Police officers at women's police stations were now exclusively responsible for the handling of all cases of violence against women, except homicides, which remained under the division of homicides. Officers were expected to follow standardized procedures, including the collecting detailed data regarding every report. Until then, police did not have much data on domestic violence cases because information about the relationship between the victim and the perpetrator excluded (da Fonseca et al., 2011). According to the Law, if victims want to drop the charges, they should be referred to the courts. Cases of physical injury, in particular, should be forwarded to prosecutor's office, regardless of victim's preferences. Police officers should also not allow victims to deliver notifications to perpetrators. Many advocates however witnessed officers not fulfilling these requirements. In particular, officers gave victims notifications to be delivered to perpetrators, requesting them to appear at the station for a conciliatory meeting. Because of situations like these, the current law also establishes a mandatory arrest policy.

As such, if it were determined that there was an imminent risk of physical or psychological injury to a victim, judges should immediately demand the arrest of the perpetrator 
or issue a restraining order, which should be provided within 48 hours. Prosecutors and judges should no longer use the Law 9099/1995 to decide cases of domestic violence (Pandjiarjian, 2006). For example, this means that they could no longer sentence perpetrators to provide community services or pay fines. Instead, state governments are required to create specialized courts to deal exclusively with cases of violence against women, where trained officials would fully consider each case according to the Law 11.340. Regarding punishments, conviction of crimes of physical injury could lead to imprisonment for up to three years, instead of one year, as was the case previously (Santos, 2010). According to the Law specialized courts also gained jurisdiction over issues of civil nature related to the crime (Brasil, 2006). Judges could also impose compulsory visits to rehabilitation programs and could not dismiss based on lack of evidence. Decision-makers, therefore, are required to consider a victim's accounts as evidence, given that most cases of domestic violence occur inside the house and do not have witnesses. Also, there is a requirement that victims need to be informed about all the proceedings, and should always be accompanied by a public defender during court hearings. Finally, the law also requires cooperation between police, courts, and several other institutions. An important aim of the new Law is the provision of an integrated service system where victims of domestic violence could have access to various types of services in the areas of health, public safety, education, social assistance, culture, and justice so as to allow women with opportunities to break free from abusive relationships and all forms of violence. In this sense, police and courts are supposed to assess all types of violence against women.

The law defined domestic violence as any action or omission that caused death, injury, physical, sexual or psychological suffering, and material or moral damage (Santos, 2010). It is also acknowledged as a violation of human rights that is rooted in the uneven power relation 
between genders in a patriarchal society. According to the Law, decision-makers should understand that domestic violence is an outcome of male domination over the feminine identity and the female body. The acts of domination are externalized as aggressions, injuries, homicide, threats, humiliations, psychological torture, exploitation, controlling behavior, material neglect, unequal distribution of family responsibilities, abuse of power, and sexual violence, among others (Santos, 2010).

Thus, given this broader view of male domination, only women should be eligible to claim protection from domestic violence under Maria da Penha Law at specialized police stations and courts. Nevertheless, both men and women can be considered perpetrators, since domestic violence can occur in any relationship with or without family ties, regardless of where the perpetrator lives or lived with the victim, or the nature of cohabitation. For example, granddaughters or sisters-in-law could be considered perpetrators. The same applies to romantic relationships between women, but men.

Police procedures in domestic violence cases according to Law 11.340/2006. Maria da Penha Law defined the new roles of the police stations. According to the law, police stations are now responsible for providing police protection and, whenever needed, immediately contacting the prosecutor's office and the judiciary. They are also responsible for directing victims to appropriate health institutions and crime labs (Instituto Medical Legal), where forensic police collect evidence of physical injury. In addition, police stations are responsible for providing victims and their dependents with transportation to shelters. Police officers must accompany victims to their houses if they need to retrieve their belongings. In this case, police officers are expected not only to be aware of all the network and services provided by other institutions, but also be proactive in seeking and maintaining relationships, such as networking with other social 
institutions. Police officers must be thus trained and educated by taking courses on public safety offered by national training institution. The military and the civil police must also develop synergy and cooperation in the handling of domestic violence cases. Accordingly, a military officer must always accompany a victim to the closest women's police station or to a regular police station near her residence or where the crime occurred (Defensoria Pública do Estado do Pará, 2008).

Also, the military and civil police must promote better integration between the investigatory institutions, including the civil police, the military, the prosecutor's office, the judiciary, and the prison system. According to the law, all activities at police stations should aim at preventing and eradicating violence, with an understanding that cases of domestic violence are not restricted to only the ones prescribed by the law Maria da Penha. Finally, officers attending to the victims of domestic violence must listen to victims with professional and observant attention, allowing victims to break the silence and the feelings of isolation (Defensoria Pública do Estado do Pará, 2008).

\section{Court procedures in domestic violence cases according to Law 11.340/2006. A}

prosecutor is the head of the Public Ministry (Ministério Público) and is under the jurisdiction of the state Attorney General (Procurador Geral). According to the law, victims should have access to legal counsel in police stations and at courts. Once a victim expresses her wishes to file a report, the police authority should start an inquiry. The inquiry should include the accounts of the victim, the aggressor, witnesses, and any other evidence. Upon completion of a police investigation, a report is forwarded to the prosecutor's office. After receiving the report, the prosecutor can decide whether a case has sufficient evidence or require the police to conduct more investigations. After the evidence is collected and verified, the prosecutor forwards the 
case to a judge. The prosecutor has the power to seek urgent protection for a victim, in case her life is in danger. Although judges usually make this decision, prosecutors have the power to request these urgent measures to be done within 48 hours. Some of the measures include preventive custody of the aggressor. According to the law (Brasil, 2006), the judge can also require that the aggressor be removed from their house, cancel their license to carry weapon, and require that an aggressor refrains from approaching a victim and even state a specific minimum distance. Additionally, a prosecutor can make recommendations about the charges. The victim or her family is allowed to hire private attorneys to assist with the prosecutor during investigation and trial. Once the judge hears the accused, the victim, and the witnesses, determines that there is sufficient evidence, and hear both the prosecutor and the defense, she or he will then decide. While the case is being heard, the prosecutor presents the charges, proposing sentences that may range between three months to three years of detention (Brasil, 2006). The special court of domestic and family violence should have jurisdiction over criminal and civil issues related to the domestic violence case. The judge can also decide on such issues, including divorce, child custody, alimony, and separation. Cases of homicide are sent to a jury trial, which makes its final decisions through a secret ballot with questions formulated by the judge and can respond with yes or no.

According to the law, a special court is staffed by social workers and psychologists, who support not only the victims but also assist the judge with reports about the psychological health of victims and batterers (Defensoria Pública do Estado do Pará, 2008). Typically, all involved institutions form a network which should actively cooperate with one another. Such a network system includes police stations, specialized courts, shelters, reference centers, health centers, military police, employment agencies, defender's office, prosecutor's office, municipal guards, 
and fire departments (“Observe: Observatório da Lei Maria da Penha,” 2010). Women should have quick and easy access to any social assistance program that facilitates her independence and transition out of an abusive relationship, especially if she is economically dependent on the aggressor (“Observe: Observatório da Lei Maria da Penha,” 2010). The law also provides guarantees for job security, stating that a woman who is a victim of domestic violence cannot be fired from her work if she needs to be absent for a period of up to six months. It also provides victims with access rights to legal abortion and health treatment for sexually transmitted diseases. The law also requires training to be provided in a consistent manner to all institutions of law enforcement. Regarding other preventive educational measures, the law supports the development of research, programs to eradicate domestic violence, and efforts to increase awareness of domestic violence issues. Given these developments, a national report concluded that the Law Maria da Penha, at least on paper, could be considered one of the most advanced and comprehensive legislation to confront domestic violence in Brazil (“Observe: Observatório da Lei Maria da Penha,” 2010).

\section{Reluctance and Claims of Unconstitutionality: A Backlash from Judges}

There was a major resistance to the Law during the initial process of its implementation. On their part, police officers continued dismissing victims, trying to conciliate them with perpetrators, or referring cases to misdemeanor courts. Prosecutors and judges continued to receive these cases and give low penalties even in crimes of physical injury. Some judges argued the law was unconstitutional because it violated principles of equality and justice, and also since it was against God’s law, as understood by Christians ("Juiz considera lei Maria da Penha inconstitucional e diabolica," 2007). Since the $16^{\text {th }}$ century, the most predominant religion in Brazil is Christianity. During the 2000 Census, $22 \%$ of the respondents declared themselves 
Protestants and 64\% Catholics. Brazil has the largest number of Catholics in the world (IBGE, 2009).

Judge Edilson Rumbelsperger Rodrigues, affiliated with a family court in Rio Grande do Sul, the southern part of Brazil, dismissed all domestic violence cases claiming the law was not only unconstitutional, but also diabolic and a threat to the family ("Juiz considera lei Maria da Penha inconstitucional e diabolica," 2007). Here is an excerpt of one of the judge's decisions: The human disgrace started in Eden because of the woman. We all know it. It was also because man was naïve, stupid and emotionally fragile. The world is masculine! God is male! Jesus was a man. State's interference on domestic violence will only turn men dumb. The so called modern independent woman, who needs nothing but men's sperms to bear a child, is nothing but a frustrated being. ("Juiz considera lei Maria da Penha inconstitucional e diabolica," 2007) During an interview for a magazine on legal issues ("CNJ avalia decisao que tachou lei Maria da Penha de monstrengo,” 2007), Judge Rodrigues reinstated his beliefs:

I believe that women should be submissive to men, how it was back in the days. She should dedicate herself exclusively to the man she loves. Men should not commit the mistakes they have done in the past, so things will not end up the way they are now. Let's say, in the past, if a woman wanted to get her husband's shoes, he should not have allowed her to do so. Had he done that, women would not want to be so independent. We recognize this mistake. So what? Now comes Maria da Penha Law recognizing that men are guilty of not valuing enough that sweet faithful woman who gave herself entirely to him. He is the one suffering now. Is she going to commit the same mistakes that he 
committed in the past? ("CNJ avalia decisao que tachou lei Maria da Penha de monstrengo," 2007)

His remarks were brought to the attention of the National Council of Justice. In November 2010, the council made a decision which considered his comments discriminatory and suspended his judicial license for a period of two years. Overturning the decision, the Supreme

Federal Court understood that the judge was exercising his freedom of speech. In February 2012, the Supreme Court also confirmed that Maria da Penha Law was constitutional. Given several appeals to the law and cases where judges refused to apply it, in December 2007, President Lula requested the Supreme Court to verify the legality of the law. The Court unanimous decided that the law promotes equality, since women are the victims of male aggression in over $90 \%$ of the cases. The Court's confirmation contributed to the further expansion of specialized police units and domestic violence courts around the country. It also reinforced ties between the government and advocates.

\section{Overview of Developments and Issues in Domestic Violence Policy (1985 - present)}

Since 1985, hundreds of police stations have been established throughout the country. In addition, there has been a rapid increase in the number of domestic violence cases being reported, greater awareness about Maria da Penha Law, and comprehensive compilation of data on the national status of domestic violence. Despite these positive outcomes, government and advocates have identified several issues delaying effective implementation of the policy. The main issues include the lack of police stations in rural areas, the fewer number of cases in the judiciary, and the poor treatment of victims at police stations.

The number of police stations had increased from six to 470 between 1985 and 2015 (Souza \& Cortez, 2014). The first cities to establish specialized units in 1985 were São Paulo-SP, 
Belo Horizonte-MG, Cuiabá-MT, Curitiba-PR, Florianópolis-SC, Recife-PE, and Vitória-ES (Souza \& Cortez, 2014). Less than ten years later, in 1993, there were 125 police stations in the country (Pasinato \& Santos, 2008). Numbers kept rising, from 307 in 1999 to 340 in 2004, and then 403 in 2008 (Silva, 2004). By 2010 there were also 165 centers of reference, 72 shelters, 58 specialized public defender's offices, 21 specialized prosecutor's offices, 12 centers of reference for the aggressor, and 89 domestic violence courts ("Balanço: Pacto Nacional pelo Enfrentamento à Violência contra as Mulheres,” 2010).

A government study about the demographics of individuals working at women's police stations identified that $45.4 \%$ of the police force was female and $27 \%$ male, although $27.5 \%$ of the respondents did not reveal their sex (“Observe: Observatório da Lei Maria da Penha,” 2010). The study also asked how many had received training about domestic violence and how to treat victims. Of the104 participants, four had received training before 2006 and 22 after 2006, when Maria da Penha Law was enacted (“Observe: Observatório da Lei Maria da Penha,” 2010).

Women's police stations also observed a rapid increase on the demand for their services. By 1998, a unit in Londrina-PR had filled 19,788 reports since its creation in 1986. The national count by the Brazilian Department of Justice showed an increase from 123,131 reports in 1993 to 425,935 in 2004 (Silva, 2004). The increase in demand continued after the enactment of Maria da Penha Law in 2006. A unit in Belo Horizonte-MG registered 7,005 cases in 2005, 5,751 in 2006, 6,433 in 2007, 11,505 in 2008, and 15,437 in 2009 (Pasinato \& Santos, 2009). Between January and December of 2008 the national women's call center received about 269,977 calls, an increase of $32 \%$ when compared to 2008, when the center received 204,978 calls (Pasinato \& Santos, 2009). 
Looking at the types of reports and demographic of clients, the study concluded that most complaints were related to cases of physical injury and threats. Among the 1,849 domestic violence reports filed in 1999 at Londrina station, $43 \%$ concerned body injury, $41 \%$ concerned threats, and six percent concerned sexual harassment or rape (Pasinato \& Santos, 2009; Galvão \& Andrade, 2004). Studies also provided information regarding the demographics of victims (Pasinato \& Santos, 2009; Galvão \& Andrade, 2004). Among the 470 women attending a victim's center in Londrina-PR in 2001, 47.2\% were married, 54\% had one or two children, $38.7 \%$ declared themselves as the heads of their households and were 34 years old (Galvão \& Andrade, 2004). Another study found that the majority of the women who contacted the national women's call center in 2009 were Black (37.6\%), between 20 and 40 years old (52.6\%), married (23.8\%) and had partial or completed primary education (32.8\%) (CFEMEA, 2011). A study about the race of women killed between 2003 and 2008 showed a decrease on the number of white victims and an increase of the number of Black victims. There were 4.7 Black women killed, compared to 3.2 white women killed per 100,000 female victims (Waiselfisz, 2011). Increased visibility on issues of domestic violence granted Maria da Penha Law the title of most known law in the country (Pasinato, 2010). In a national survey conducted in 2009, approximately $78 \%$ of men and $83 \%$ of women were aware of the law and its content (Pasinato $\&$ Santos, 2008). Half of the interviewees knew at least one victim of domestic violence (Ibope, 2009). Despite increased awareness, advocates noticed that police stations were concentrated around large metropolitan areas, located in about 10\% of the municipalities (Secretaria Especial para Mulheres, 2007; Santos, 2010). Out of the 398 police stations established by 2005, 40\% were located in São Paulo and Rio de Janeiro (Diniz, 2006). 
Feminist groups also observed that very few cases were going to the judiciary. It was found that among the 19,788 reports registered in Londrina between 1986 and 1998, only 10\% were properly investigated. In a study conducted in 1999, it was found that police officers encouraged victims to forgive their aggressors in $95 \%$ of the cases. Only $6 \%$ of the complaints received were sent to the judiciary (Silva, 2004). Overall, police officers preferred taking on the role of mediators (Soares, Soares, \& Carneiro, 1996; Muniz, 1996; Brandão, 1998).

Police stations usually operated according to one of three models: bureaucratic, hybrid of bureaucratic and mediation, or social-psychological (Jubb \& Izumino, 2003). The first favors bureaucratic services, where police activity revolves around filling out reports and later forwarding them to the judiciary. This type of approach was observed in police stations in São Paulo. The second was a mix of police activity and mediation initiatives, where police often warned aggressors of the potential consequences of their behavior, and only followed judicial channels as last resort. According to the study (Jubb \& Izumino, 2003), it was found that about $42.7 \%$ of the stations in the country adopted this role. The third model combines police attention with psychological-social attention, where policewomen focus on listening to victims. This type of approach was observed in four states in the Northeastern region of Brazil (Amaral, 2001). Perhaps aware of this reality, studies also found that women preferred going to regular police stations, instead of the specialized unit. In São Paulo, 17.6\% of the women victims of physical injury or sexual violence went to the regular police station, while $13.7 \%$ went to the women's police station. In the rural area of Pernambuco, a state in the Northeastern region of Brazil, 10\% went to the ordinary station, while $0.5 \%$ went to the women's police station. Victims reported that policewomen were as dismissive as male officers (Nelson, 1996). This may have been due to the lack of training in women's police stations. Female officers expressed not only reluctance in 
working with domestic violence, but also lack of knowledge regarding its complexity (Nelson, 1996; Santos, 2008).

Despite the uneven national distribution of police stations and poor treatment of victims in some cases, one of the best outcomes of the policy was it emphasis on the assessment of how many cases of female homicide were due to cases of domestic violence. National studies showed that in over $70 \%$ of cases the crime was committed inside the house ("Balanço: Pacto Nacional pelo Enfrentamento a Violencia contra as Mulheres," 2010; Waiselfisz, 2012). They also revealed that approximately 91,000 women had been killed in Brazil between 1980 and 2010 (Waiselfisz, 2012). With a national index of 4.4 deaths per 100 thousand women, Brazil was placed in seventh place among 84 countries, after El Salvador (10.3), Trinidad and Tobago (7.9), Guatemala (7.9), Russia (7.1), Colombia (6.2), and Belize (4.6) (Waiselfisz, 2012).

\section{Implementation of the Domestic Violence Policy in Espírito Santo}

The rapid urbanization of Vitória, as a port city, began in the 1960s, due to increased economic revenues from the export of coffee (Nader, 2009). Around the same time, another industry, iron and steel, was being established, raising the profile of Vitória's port worldwide. In thirty years the population of Vitória tripled from 83,000 in the 1960 s to 207,000 in the 1980s, mostly due to the influx of migrants from neighboring states (Nader, 2009). Change in the demographics of Espírito Santo has been occurring since the colonial times, with the arrival of Portuguese and Africans, and later at the end of the 19th century, with the influx of Italians, Germans and Arabs (Nader, 2007).

According to Nader (2009), since the early 1970s many prominent cases of violence against women have occurred in Vitória. In 1973, Araceli Crespo, a nine years old girl, was tortured and killed. In the mid-1980s Ana Angélica Freitas Ferreira, a 22-year old dentist, was 
murdered inside her office. In 1992, Maria Cândida Teixeira's husband murdered her at her doorsteps. Also during the early 1990s, Gabriela Souza's boyfriend threw her off of a building after she ended their relationship. Most of these cases were not prosecuted.

Local activist groups mobilized protests seeking accountability for these and other cases of violence against women committed in Vitória at the time (Nader, 2009). A local interest group, the Centro da Integração da Mulher Capixaba-CMI submitted a request to the state government on August 1985, soliciting the creation of a specialized unit to deal with crimes against women. The Decree 2.170, signed by the governor on October 241985 established the creation of Espírito Santo's first women's police station. Between 1985 and 1990 other police stations were established in other regions of the state, including the one in Cachoeiro do Itapemirim, visited during this study. Although the new police station had its own building, it had limited space for its staff and storage. All documents related to cases since its establishment in 1985 until 2002 were placed in other storage buildings that belonged to the police headquarters (Nader, 2009).

When it was first created, the Vitória police station was solely responsible for the investigation of crimes that occurred in five neighboring cities: Vitória, Vila Velha, Cariacica, Serra, and Viana (Souza \& Cortez, 2014). The establishment of the policy in the State of Espírito Santo was the result of a federal government directive imposed on the police. According to an officer, the creation of the police stations was a big surprise (Officer 1, female, personal communication, July 27, 2013). It was an imposition from the federal government and the civil police upon the local chief of police. The police did not have any support from the local or state governments, and had to raise the resources to improve the structure of police stations. A police commander noted that police officers were transferred to a local police station, but when they 
arrived there, it was empty (Officer 7, female, personal communication, October 10, 2013). The previous staff, which was transferred to a newer building, took all the furniture with them, leaving behind an old bench, an office chair, and a plant vase. After the chief of police gathered resources from the community, and painted and equipped the building, they had to relocate because the government did not renew the lease contract on the building. It wasn't until 2002 that the women's police station received its own building, a poorly refurbished small old house a few blocks away from the police headquarters (Jubb, 2001).

Until 2002, Vitória's police station was established in an office room at the police headquarters. In 2002, the police purchased a house a few blocks from the headquarters, and transformed it into the women's police station of Vitória (Nader, 2009). Until 2013, when this interview was conducted, they had had relocated four times. A prosecutor noted how, "Nobody wanted to work at the women's police station" (Prosecutor 3, female, personal communication, October 17, 2013).

With the enactment of the Law 9099 in 1995, misdemeanor criminal and civil cases were sent to the newly created specialized courts (Judge 6, male, personal communication, October 16, 2013). As it was explained earlier in this chapter, the law was an attempt to reduce the number of cases in the judiciary, as well as expedite the decision-making process. Although this law did not specifically address cases of domestic violence, cases of physical injury involving spouses were sent to these courts. According to the law, all cases were supposed to go through a conciliatory process. The parties involved would sit with a mediator, who would encourage them to reach an agreement or encourage the victim to pardon the accused. Domestic violence cases were not treated differently. According to a police officer, the conciliatory approach became standard at the police station until 2005 (Officer 2, female, personal communication, July 29, 
2013). In a group discussion with three officers, one of them said that domestic violence cases were daily occurrences and were considered "fights without importance, not a real police case" (Officer 15, male, personal communication, December 6, 2013). Their police commander would then talk to them, because "she knew they [the victim and the batterer] would go back anyway" (Officer 18, male, personal communication, December 6, 2013). Another officer added that at most they would "snap the guy's ear, scare him, because that is what most women want. Today it is different...it is jail" (Officer 16, female, personal communication, December 6, 2013). Moreover, the majority of the interviewees said that police procedures prior to the enactment of Maria da Penha law were dismissive. On the other hand, four female officers emphasized that the conciliatory system was "efficient and the victims liked it quite a lot [because] the problem was solved rapidly" (Officer 3, female, personal communication, August 20, 2013). According to the interviewees, officers had more discretionary power. They could challenge the victim's statements in order to verify whether she lied because she was nervous. They also had less work, since only " 10 or $20 \%$ of the cases were sent to investigation and forwarded to the courts" (Officer 20, female, personal communication, August 20, 2013). They would tell the victims to "give it some time and go back in ten days to fill out the paperwork" (Officer 3, female, personal communication, August 20, 2013). In most instances the case was archived for "lack of interest." Another officer added that:

Most victims just wanted us to call him [the aggressor] here to talk, which was enough to scare him. Almost none of the cases needed further investigation. We had the option to conciliate them and the process was efficient. The victims were much more satisfied back then. It was much better. Now, unfortunately, things don't go well. They don't 
understand the process. When I explain that the paperwork still has to be sent to the judge (Officer 2, female, personal communication, July 29, 2013).

Offering a different opinion, a local women's rights activist stated the following:

The decade between 1995 and 2005 was the worst period for victims of domestic violence; she would go to the police and show what was happening to her, but everybody would try to get her to forgive the guy. Even after cases went to the judiciary, the most severe judicial decisions imposed the aggressor to either engage in a number of hours or community service or pay an amount equivalent to a number of food baskets. Only cases of homicide had immediate access to the judiciary, but decisions were usually less punitive than what the law determined. (Advocate 2, female, personal communication, October 10, 2013)

It is only in 2006, with the enactment of the Law Maria da Penha, that the police developed a more uniform and systematic collection of data procedures. The enactment of the LMP in 2006 was considered a landmark decision in the women's rights agenda in Brazil. It challenged the police to develop a new mindset toward domestic violence crimes, as well as follow standard procedures and definitions according to a feminist agenda. The feminist movement had active participation in the drafting of the legislation, developing a broad definition of domestic violence as an act driven by machismo and manifested as psychological, physical, or patrimonial abuse. Thus, in order to address the patriarchal nature of such violence, police stations needed to deal specifically with cases of domestic violence suffered by women. Male victims needed to seek assistance at regular police stations. Nowadays, domestic violence cases involving male victims are treated under the law 9099/95 or the Brazilian Criminal Code. The same applies to female victims of non-domestic violence crimes. LMP also prescribes the 
training of police officers as a way to facilitate an organic transition toward the new system, composed by better institutional support inside and outside police stations.

Despite these advances, the current system is still fragile. Police only collect statistics on the crimes they prosecute, policewomen are not trained to recognize other forms of violence and have relatively distant relationship with the feminist movement that triggered the creation of women's police stations. However, there is a focus on crimes of physical injury and threat perpetrated by partners or spouses, while other crimes such as sexual violence, psychological injuries, and property crimes are usually ignored (Jubb, 2001). Spousal violence accounts for $70 \%$ of the cases in women's police stations (Santos, 1999).

Currently, the women's police station has jurisdiction only over crimes that occurred within the city of Vitória, given that all the other cities now have their own specialized units. Crimes against minors or elders are forwarded to their respective specialized units. Regarding the volume of cases, in 2005 and 2006, when Maria da Penha law was implemented, there were respectively 1,356 and 1,173 cases registered (IBGE, 2009). The decrease in 2006 is possibly due to the fact that the police station focused on cases of domestic violence and forwarded other cases to other police stations, although it is also believed that such reduction is due to the population's lack of trust or doubts towards the new law (Souza \& Cortez, 2014). In 2009, there was another increase, with approximately 2,000 cases, and another decrease in numbers in the following year, with 1,669 records. When police officers, judges and prosecutors were asked why the state had such a high percentage of domestic violence cases and deaths, about $60 \%$ percent believed that the results did not reflect the reality. A judge summed it up well, saying that it was because "the state was small, had at least one police station in every city and also had 
a better tracking system than the other states" (Judge 2, male, personal communication, October 16, 2013).

As observed, the implementation of the domestic violence policy in Espírito Santo was also marked by political interest, pressure from advocates, and, surprisingly, reluctance from those who were assigned tasks to which they received little training and structure. Despite eight years of implementation of Maria da Penha Law, perceptions about domestic violence crimes still contradict those of people who deal with victims on a daily basis at police stations and courts. The following chapter will focus on other aspects that influence the rationale of police officers' decisions and actions when dealing with cases of domestic violence.

\section{Conclusion}

The development of domestic violence policy in Brazil shares a similar path, with the one taken in the United States. The Brazilian feminist movement from the 1980s not only challenged the country's colonial laws that allowed men to physically punish women, but also spurred a major change in the political and legal frameworks. The country's political structure, organization of police force, and legal system were transitioning from a period of military dictatorship to democracy. During this period, the Brazilian feminist movement exercised great efforts in lobbying the federal government to advance women's rights and raise awareness about how victims of domestic violence were treated at police stations.

The political partnerships developed between feminist interest groups and the government was one of the main reasons why the creation of women's police stations in 1985 happened. However, there was a major disparity between the goals of the women's movements and those of the government. The Brazilian feminist movement aimed at establishing a systematic network of social, psychological, and legal assistance, coupled with shelters, 
educational resources, and trained police officers. The federal government, on the other hand, was reluctant to include in its programs the agenda issues related to women, including women's rights to gainful employment, to vote, and to receive family inheritance. At the time, the federal government had signed in partial the agreement of the Convention on the Elimination of All Forms of Discrimination Against Women. Over the years, the government continuously excluded women's rights advocates from participating in political decisions and refused to train police officers about how to work with cases of domestic violence, despite an increase in the number of women's police stations across the country. By the 1990s, there was a drastic increase on the number of cases in those stations. Nonetheless, advocates indicated that police officers mistreated victims, avoided filling reports, or attempted to conciliate victims with their batterers. They also pointed out that police officers who worked at women's police stations, majority of them being women, did not want to work with cases of domestic violence and did not consider their responsibilities as real police work. It is believed that about $70 \%$ of the cases got archived for lack of victim's interest.

Another major legal development that culminated in the implementation of domestic violence policy in Brazil was the enactment of law 9099 in 1995. The law provided for the creation of specialized criminal misdemeanor courts to expedite traffic of misdemeanor cases, clean records of the accused, encourage the use of community service as penalty, and seek conciliation between parties. These courts became the gateway for less than $30 \%$ of domestic violence cases that made it to the judiciary. Advocates pointed several unintended consequences of this strategy: victims being encouraged to forgive the perpetrator, aggressors being sentenced to provide food baskets or community service, and victims with a sense of impunity, without assurance of safety, and perhaps unwillingness to seek assistance at courts. The only positive 
consequence was the visibility it brought to the number and severity of domestic violence cases that needed judicial attention.

About the same time, the Brazilian federal government was in the process of adopting the United Nations human rights approach. Brazil and the Organization of American States had already approved the Convention of the Elimination, Prevention, Punishment and Eradication of all Types of Violence Against Women. While the human rights approach was being codified into the body of Brazilian legal system, domestic violence was becoming framed as a human rights issue. The convention also gave legitimacy to local feminist and human rights organizations to raise issues in the international arena. Promptly, advocates engaged in transnational legal mobilization to bring to international attention the issue of how victims were being treated at police stations and courts. Evidence that showed a pattern of discrimination and neglect toward cases of violence against women was brought to the attention of the Inter-American Convention to prevent, sanction, and eradicate violence against women in 1996. The Convention urged Brazil to take immediate action to address domestic violence in the country. The Brazilian government created an office for the development of policies that focused on women's rights and enacted a law that marked the official establishment of domestic violence policy in Brazil, Law 11.340/2006, also known as Maria da Penha Law.

Among the major changes brought about by the new law were the limitation of discretionary powers of police officers, prosecutors, and judges; the establishment of standardized procedures, data gathering, pro-arrest and issuance of restraining orders, and deadlines to follow legal proceedings; a ban on the use of law 9099/95; a provision of a broader definition of domestic violence; and the limitation of the eligibility only to women. There was major resistance to these changes during initial process of legal implementation, especially from 
judges, who claimed the law was unconstitutional because only women could press charges of domestic violence. Claims went to the Brazilian Supreme Court who later confirmed the law's constitutionality.

In Espírito Santo, the policy was perceived by the police as an imposition from the federal and local governments. The local police was frustrated because they had to create women's police stations within a short notice, without funding, staff, and training. Police stations had to drastically change the way they handled domestic violence cases. The state also created domestic violence specialized courts. Police officers and criminal justice professionals did not expect the high demand of cases that resulted from these developments and showed great frustration with the policy implementation

Today, the policy has high visibility in the Brazilian society. Every state has at least one specialized police station on domestic violence. There is an increasing number of victims reporting cases, and also a system that keeps track of the numbers of cases at local and national levels. Increasingly, however, very few cases reach the judiciary and police officers continue to be reluctant in working with cases of domestic violence, as many of them believe the policy to be unfair, inefficient, and unnecessary. Chapter three describes the ways in which police officers are helping or hindering the implementation of domestic violence policy in Espírito Santo, and what aspects they find relevant to investigate when engaging with victims. 


\section{Chapter 3: Police Perspectives about Domestic Violence Policy}

This chapter is based on interviews and observations conducted at police stations and specialized courts in Espírito Santo, Brazil. After the presentation of research methodology, the chapter provides a description of police perspectives about domestic violence policy broken down into six categories, namely: (a) opinion about Maria da Penha Law; (b) institutional constraints; (c) factors influencing decision-making; (d) feelings about their work; (e) perceptions about their role in policy implementation; and (f) perceptions about interactions with other institutions. The chapter will then end with a conclusion of main themes.

Police officers can be considered the gatekeepers of domestic violence policy in Brazil. The police station is usually the first point of contact between victims and the criminal justice system. In order to fulfill their responsibilities, police officers engage in various activities while simultaneously dealing with great frustrations resulting from internal and external forces.

\section{Research Methodology}

This study primarily used a qualitative approach in order to identify individual's thoughts, feelings, perceptions, and hidden biases on domestic violence policy and its implementation. The subjects or respondents were police officers, prosecutors, and judges from the State of Espírito Santo, Brazil (see figure 1), who work with cases of domestic violence. Specifically, the respondents worked in specialized

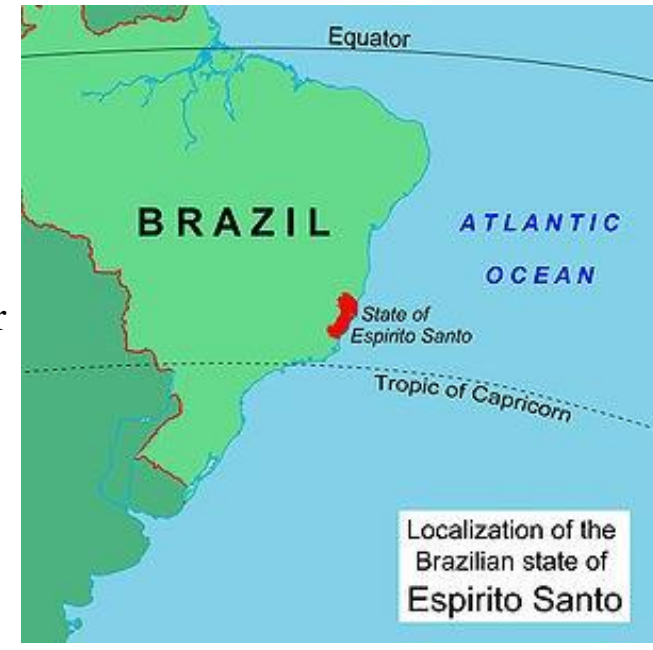

Figure 1: Localization of the Brazilian state of Espírito Santo. courts and police units. The latter are known as women's police stations. This study chose the State of Espírito Santo, primarily due to its 
reputation as one of the most violent states of Brazil, consecutively remaining at the top position since 2008. In 2011, Espírito Santo had an average of 21.4 deaths per 100,000 women. The national average was 7.1 per state and 9.3 for the state capital. The capital of the state, Vitória, also ranks first among the capitals in Brazil, with an average of 40.9 homicides per 100,000 females. Espírito Santo also stands out due to its geographical position, recent economic development, and diverse population. Espírito Santo is located in the Southeastern region of Brazil, the most economically developed region of the country, and in which the states of Rio de Janeiro, São Paulo, and Minas Gerais are located. Espírito Santo, the largest producer of petroleum in Brazil, has a population of 3.5 million and, yet, has well preserved its rural characteristics (IBGE, 2009).

As Brazil has a unified system of laws and regulations, the state presents a representative sample of the national legal system. The state also reflects the diversity of the Brazilian population, an amalgam of cultural influences, including from Amerindians, Portuguese, Africans, Italians, and Germans (IBGE, 2009).

Interviews and observations were conducted in five of the seven women's police stations that

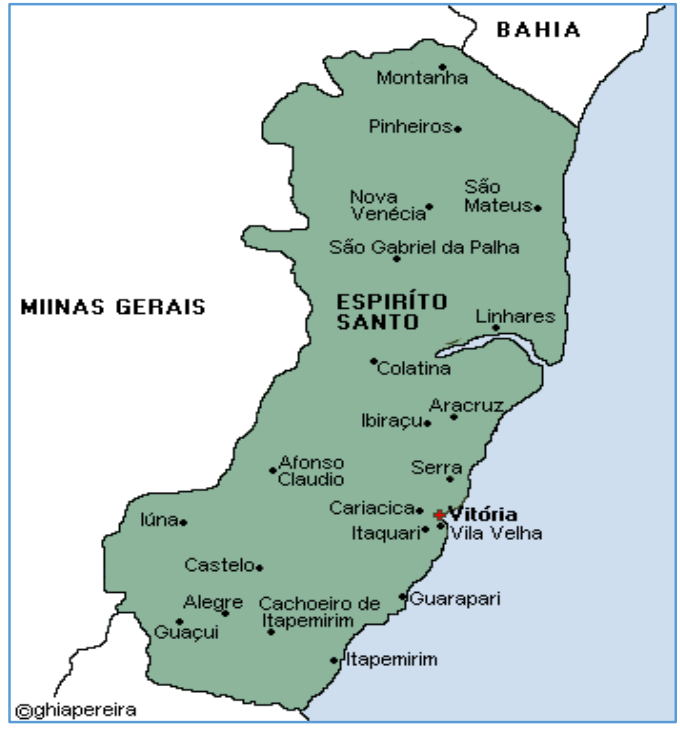

Figure 2: Map of the state of Espírito Santo, Brazil. existed in the state of Espírito Santo between 2012 and 2013, when this study was being conducted. The chapter is based on interviews and discussions conducted with 20 respondents, among police officers and commanders, and the observation of 20 cases. All the responses were recorded and later transcribed. 
During the interviews, the respondents were asked about their opinions about the domestic violence law, institutional constraints, and feelings about work, perceptions about their own role in the law implementation, and perceptions about their interactions with other institutions. Interview questions are available in Appendix A.

During the observations, the focused was on how often police relied on non-legal factors to have a better understanding of domestic violence cases. Legal factors are those related to the facts, usually prescribed or defined by law, such as type of injury, day and location of event, witnesses, and if the victim is related to the perpetrator. Yet, officers often consider non-legal factors when they ask victims about information that might not be legally relevant. Examples of such information include history of addiction, employment status, if the victim loves the perpetrator and how long they have been together, or if they have children, etc. The examination of how often police officers asked these questions provided an a reasonable understanding of what police officers find relevant to know while evaluating cases of domestic violence.

A similar approach was used in court hearings, in order to investigate the factors influencing the decision-making and the perceptions of prosecutors and judges, the focus of Chapter four. Chapter four is based on the interviews and observations conducted in seven criminal courts from seven different cities in Espírito Santo. Court and case observation forms are available in Appendices B and C. Four of these were courts specialized in domestic violence cases. The remaining three had criminal courts with designated days to hear domestic violence cases. Interviews were conducted with three judges, eight prosecutors, two public defenders, five defense attorneys, and four court officials, summing up to a total of 22 court respondents. The observations conducted in all of the courts were on total of 64 cases. While interviews targeted perceptions and opinions about domestic violence policy and its implementation, observations 
focused on how prosecutors and judges interacted with victims. The latter focused on what prosecutors and judges choose to ask victims at court hearings. The questions asked what legal or non-legal factors prosecutors and judges find relevant to ask the victim, in order to guide their decision-making while handling cases of domestic violence. In sum, this study conducted a total of 42 interviews and observation of 84 cases.

\section{Police Officers and Their Opinion about Maria da Penha Law}

Despite having some positive opinions about the law, most interviewees reported that they had problems adjusting to the increased workload and the change in routine. The interviews suggest that, currently, police officers remain skeptical about the policy. Among the highlights of the positive opinions about Maria da Penha Law are these comments below:

Compared to other laws in Brazil, this one works. This is the only law that can send someone to jail based solely on what the victim says. I've heard men asking "why are you arresting me now, if I have been beating my wife for years?" Men think nothing is going to happen with them, but it does. If he doesn't pay the bail, he is going to prison. Nowadays, who can afford paying one monthly salary on the spot?" (Officer 19, male, personal communication, July 25, 2013)

Many officers emphasized that the law was a historical landmark because it provided women with places to seek assistance, such as the police stations, where they also have access to justice and other services from social workers and psychologists. As an officer added:

Something had to be done someday. Before it was rare to hear of these cases, but now, with the media, it is all the time. It certainly has prevented deaths. I can't imagine how it would have been without this law. (Officer 16, female, personal communication, December 6, 2013) 
Regarding the process of adaptation or adjustment to the requirements of the Law, a Commander shared that police officers did not expect a rapid increase on the number of women visiting the women's police stations. Yet, officers were frustrated because they were not equipped to deal with the new workload and since they were forbidden from engaging in conciliatory roles. Instead, they had piles of paperwork to fill out, and limited staff to answer calls and talk to victims. Talking about the work routine at women's police station before the Law, an officer said:

They were accustomed to listening to the victims without being requested to do anything. We could drop the charges at any time. It was nothing and nothing happened, just couple's fights. The women wanted us to call them [the perpetrators] here and talk. We talked because we knew they would go back together. Sometimes we would tell the victim to return in ten days. If she did not show up, nothing would happen. Perhaps $10 \%$ to $20 \%$, at most, was sent to the specialized criminal court. (Officer 3, female, personal communication, August 20, 2013)

When asked about how colleagues reacted to the sudden change in routine, an officer said it was stressful because "it was a last-minute thing. They changed our schedules to work overnight and weekends. We received no training, nothing" (Officer 2, female, personal communication, July 29, 2013). The police station responsible for cases that occur after 6 PM and during weekends was also poorly established. The women's night duty station (Plantão Especial da Mulher) was created early in 2013 to attend to domestic violence cases that occurred after 6 PM and during the weekends. A police commander explained how she became aware of its creation while watching the news (Officer 1, female, personal communication, July 29, 2013). Later on the same day, she received a call from her superiors ordering her to assemble a group of 
officers who would take nocturnal shifts at the newly created unit. Since then, officers from various cities and police stations have taken turns responding to an excessive number of cases. Another officer remarked that he heard colleagues lamenting how they "became woman's babysitters, since they were expected to pick them up and drive them [the victims] home" (Officer 19, personal communication, August 20, 2013).

In addition to these comments of frustration-, about $80 \%$ of police officers interviewed considered the law unfair, inefficient or unnecessary. Indeed, many officers challenged the law's assumed sense of fairness, arguing that vengeful women have used the law to get their partners out of their house, to obtain child custody, or to secure possessions during an upcoming divorce. According to one officer:

The law allows women to fuck with the men. We clearly see that they take advantage of the system! In yesterday's case she said he had been arrested before, and it was a big lie! She was the one sending him texts saying "I will hunt you down, you better answer my calls or I'll go after you at your workplace. I'm pregnant and this child will never meet you." When the guy came here he was all scratched, she broke everything in his house. If she gets a restraining order, he is the one who will have to leave the house, even if it is his house! He has to leave in 24 hours! (Officer 17, female, personal communication, December 7, 2013)

Many officers echoed the above sentiments. One officer added that the system is intrinsically unfair because “women who are physically injured get the judge's full attention, but men who are injured are not even sent to do exams at the forensic police" (Officer 2, female, personal communication, August 20, 2013). In agreement with this observation, many officers believe that police stations gives full credit to whatever the women says, but men are not given 
the same attention. Men do not have the option of requesting restraining orders, despite. As an officer sees it, "women are invading their space, calling them, going to their work, turning their life in hell” (Officer 20, female, personal communication, August 20, 2013). Therefore, as one officer concluded, "there is no equality. They [the women] beat them [the men] and nothing happens, but when the men does anything, they [the women] call the police or come here" (Officer 3, female, personal communication, August 20, 2013).

Many officers also believed Maria da Penha Law was inefficient. Because, as officer saw it, domestic violence is a social issue, psychologists and social workers, rather than police, should be the first ones to talk to victims. Indeed, a commander recommended that "we should not use law and the police to interfere in family disputes. It is a social issue and criminalizing it won’t make him stop" (Officer 6, female, personal communication, December 9, 2013). Many officers share this view and believe that criminalization of domestic violence does not solve the problem, but rather creates more by allowing women to use the system against men. Many respondents believed that many women went to police stations because they were unable to solve their problems through the conventional judicial avenues. Thus, to these respondents, the roots of those disputes are civil-legal issues involving family property, child custody, divorce, or visitation rights. Moreover, according to a commander, the law is inefficient in curbing recidivism:

More punishment won't make it [domestic violence] stop. First, it is a social problem. Second, when the judge finds him [perpetrator] guilty, he will rarely go to jail. Even if he goes, let's say in a case of violation of restraining order, the next day he will be here getting his things. It is frustrating to arrest someone, only to know that the next day he 
will be back at home. I know many cops who simply don’t answer domestic violence calls. (Officer 13, male, personal communication, October 15, 2013)

About $25 \%$ of the respondents considered the policy unnecessary, given the few cases of domestic violence they had addressed. According to them, government statistics on domestic violence cases were misleading:

From all the crimes involving female victims, only $18 \%$ to $22 \%$ are real domestic violence cases. In most cases women were involved in drug trafficking or fights. Espírito Santo is the only state in the country to create a police station solely to deal with cases of women being killed, assuming that most of them would be related to domestic violence. Although the state ranks first in the killing of women, most of the women killed were directly or indirectly related to drug trafficking. Usually they are addicted to crack, cannot afford the costs of their addiction, get themselves involved with prostitution, or get in the business of selling drugs for drug dealers who are in jail...and end up getting killed...it is a sad story that people out there don't want to hear. (Officer 4, male, personal communication, September 18, 2013)Police officers were also asked why Espírito Santo often ranked first or second in incidences of domestic violence during the last few years. Approximately $40 \%$ of the respondents believed the main cause of female deaths in Espírito Santo was not domestic violence, but woman's involvement with drug trafficking. An officer explained that, "there are too many people from the northeast [an impoverished region of Brazil], who don't fix residence here, so they have no constraints to killing" (Officer 16, female, personal communication, December 7, 2013). Another officer suggested that the real number of domestic violence deaths ranges between three and seven in the state (Officer 4, male, personal communication, September 17, 2013). A third of the respondents argued that they could not trust domestic violence statistics because of 
methodological problems in data collection. In their opinion, Espírito Santo has a high index of domestic violence because the state is small and people have wide access to police stations, leading to an over report of cases of domestic violence. Other states have bigger geographical areas and fewer police stations, as one officer pointed out:

Espírito Santo is small but has police stations in every city and district. In the Amazon, you see only one police station for an area of a thousand kilometers. Here, the police are active in the entire state. The government complains that our problems are easily exposed out there, while other states cover up their deaths. The United Nations index calculates the number of crimes per every 100 thousand habitants. In general numbers, Rio de Janeiro and São Paulo have much more killings, but giving that we are a small state, we have a bigger proportion. (Officer 20, female, personal communication, September 13, 2013)

Regardless of these perceptions by officers about the realities of domestic violence, in 2013, the State Supreme Court (Tribunal de Justiça do Estado do Espírito Santo) invested heavily in the production and purchase of electronic devices. Costing $\mathrm{R} \$ 80.00$ (approximately US\$30.00) each, the devices were to be delivered to victims in extreme risk of violence. Each of the about 100 victims, whose cases Vitória's specialized court handled, received the device free of charge. Once activated, the device records any sound within five meters of distance and automatically calls the nearest police patrol in the case of unusual domestic disturbance. A judge from Vitória's specialized courts decides which victims are eligible for such devices. The initiative was highly praised nationally and judges from the State Supreme Court were honored by the United Nations. However, the policy providing electronic devices has been target of some criticisms. 
Respondents were also asked about their opinion regarding this initiative and most did not trust it. Almost unanimously, interviewees pointed out that the initiative was nothing more than political ploy to gain attention for personal gain. An officer suspiciously noted that, "coincidently, the initiative was launched during a period of nominations at the National Supreme Court" (Officer 13, male, personal communication, October 16, 2013). A commander agreed:

It was only to show off, to get attention at the media. If they wanted to cause any impact [on the cases of domestic violence], it would have been expanded to the state. It was only to gain visibility, to push for their political interests. We are the ones that get the hands dirty, working with domestic violence in a daily basis, but we are the least supported. No politician comes here to ask how we are doing or give any contribution. Police officers oppose politicians who just want to show off. They live off homage ceremonies here and there, but you don't hear of one officer being acknowledged. Instead they pat themselves on the back, honoring people from within their own circles, while the police take on the most criticisms. We work non-stop, we are practical, and the last thing we want is to show off. (Officer 14, female, personal communication, October 16, 2013) Interestingly, the police commander immediately quoted above had not received any prior information about the electronic device, although the day after it was revealed in the media, several victims appeared at the police station requesting the device. Another officer, flabbergasted, reflected that, "Back in the days the victim died holding the phone in their hands. Now they will die with this device" (Officer 4, male, personal communication, September 17, 2013). In his opinion, the device could not ensure the safety of the vast number of women in situations of extreme domestic violence. According to him, there is no police force or 
technological gadget able to provide effective monitoring and surveillance of violence everywhere, including in people's homes (Officer 4, male, personal communication, September 17, 2013).

Finally, when respondents were asked if they had suggestions for better implementation of the domestic violence policy, one officer suggested that the legal instruments provided for by Maria da Penha Law should be accessible to all, including men (Officer 10, female, personal communication, October 15, 2013). Another believed that police officers should have more discretion about what cases to file a report on (Officer 16, female, personal communication, December 7, 2013). According to her, "they [officers] should be able to give orientation or try to conciliate the victim with the batterer, so it doesn't become a police case" (Officer 16, female, personal communication, December 7, 2013). Nonetheless, many respondents listed a number institutional constraints that they faced and believed many problems would be solved if the law were fully and properly implemented. The law prescribed special training for officers, shelters for victims, and required that police stations be fully equipped with enough rooms and staff, including multidisciplinary staff comprising of psychologists and social workers.

\section{Police Perceptions about Institutional Constraints}

During the interviews, police officers shared their opinion about various institutional constraints they faced in a daily basis. Among the most mentioned constraints were the lack of proper physical infrastructure, limited staff, increased workload, inconsistencies about posting of bail and case registration, and concerns about safety.

\section{Infrastructure}

Most police stations were located in old buildings that lacked appropriate lighting, electricity, ventilation, water, and space for the staff and the influx of people coming to seek 
police services. A police officer said that although she liked working with domestic violence cases, the environment was so inhospitable that she developed allergies and felt incapable of working efficiently in such conditions (Officer 1, female, personal communication, July 29, 2013). In addition, none of the police stations were accessible to individuals in wheelchairs. The stations also lacked separate waiting areas. It was common to see victims with children sharing a room with men in handcuffs. As one of the staff members remarked, "The police station could be mistaken for a childcare facility, given the high number of children who come with their moms" (Officer 6, female, personal communication, December 10, 2013). The limited space also did not provide victims with privacy. One could easily hear victims sharing the detailed information of the acts of aggression they suffered. Most police stations were distant from municipal courts, emergency rooms, or crime labs. If victims needed to collect evidence of physical injury or verify the statuses of cases in courts, they would probably have to spend at least one extra bus fare. Moreover, police stations were ill equipped with computers, printers, cameras, and office supplies. In one of the police stations, the commander did not have her own office nor a computer. In fact, the police commander purchased the phones in her office with her own salary.

\section{Number of staff and workload}

Another major institutional constraint is the inadequacy of staff and the high volume of work in each police station. Women's police stations in Espírito Santo usually have a commander and an average of six police officers, including investigators and detectives. According to Commander Maria Aparecida Rasseli Sfalsini, from Vila Velha's police station, the station had 721 cases registered during the first three months of 2011 (Paulo, 2011). The whole of the previous year had 3.553 cases. As of 2013, Vila Velha had 427,579 habitants. Vila Velha's 
police station is one of the best equipped of the state, with 12 police officers, making it, at minimum, able to serve the city's large population.

On average, police stations in the city work on 2500 cases per year. Approximately 40 women seek help at police stations daily, although most visits are not related to domestic violence. Many women seek legal advice regarding divorce and child custody. According to officers, about ten visits are 'legitimate' victims of domestic violence (Officer 7, female, personal communication, October 10, 2013). On average, each case hearing takes at least 30 minutes, but can extend to two hours when witnesses are present. Operation hours vary between stations. Some stations are usually open between 9 AM and 5 PM, while others provide service between $2 \mathrm{PM}$ and $6 \mathrm{PM}$. One of the police stations visited during this study was closed because all the officers, including the commander, were on leave.

The number of visits is usually higher on Mondays, particularly on weeks following paydays. Officers also estimated that an increase of cases occurs between December and March, the summer season in Brazil. During this period there are carnival celebrations and widespread consumption of drugs and alcohol. A commander from one of the stations who works during nights and weekends reported attending to 22 different flagrant cases, with 24 arrests made in one night during carnival days. According to another officer, "every night they have at least ten cases. When the shift is over, one arrives at home completely drained. It takes all your energy" (Officer 12, personal communication, October 16, 2013).

Noticing the increasing workload, police have attempted to curb the entry of cases from elderly women. Police officers have denied elderly victims access to women's police stations and redirected them to the specialized police station on crimes against the elder. However, Maria da Penha Law is not explicit about this exception. It recommends that elder women be attended in 
any police station (Brasil, 2006). Perhaps wishing to reduce the burden of their workload, similarly, police officers easily accept any victims' requests to drop charges, even in cases of threat.

Victims can drop charges in cases of threat, when there are no physical injuries. These procedures are called retratação, meaning that they retract from following through with the charges. As a police officer said, "Whenever a victim asks to drop the charges she does it immediately, so it is one less case they have to deal with" (Officer 1, female, personal communication, September 16, 2013). Police officers believe that victims retract $30 \%$ to $50 \%$ of cases. Among all the requests of retratação observed in this study, officers never asked the reason why the victim wanted to halt the investigation. Perhaps charges are dropped immediately as a way to curb the volume of cases.

\section{Inconsistencies about posting of bail}

Police stations are inconsistent on the question of whether they have the legal authority to require the posting of bail. According to a commander, "some police stations post bail, while others don't, especially if there is a restraining order. Here we leave it up to the courts to decide" (Officer 18, male, personal communication, August 30, 2013). In many cases where bail was issued at the police station, the accused paid the fines and had to be immediately released, frustrating the victim and the officers. An officer described a case when the victim was severely injured but reluctant to go to the police to file charges. Her sister called the police and they were sent to the police station. He paid bond of approximately US\$ 3,000 and was released (Officer 17, female, personal communication, December 7, 2013). 


\section{Different systems of case registration across police stations}

There is no uniform reporting or database coding, making it impossible to track accurate and aggregate information about domestic violence cases around the state. Some stations recorded the number of investigations initiated and concluded, the number of restraining orders, and the number of imprisonments. Others only recorded the number of cases based on the types of crimes, such as crime of threat, physical injury, rape, attempted murder, and crimes of indecency. Another station particularly recorded the number of cases initiated at the women's police stations and cases initiated by call, and where parties were taken or transported to the police station by a police officer. Some police stations record information in a computer, while others kept hand-written files. Up until recently, the state lacked a database on the cases of domestic violence. The number of homicides related to domestic violence is also unknown.

\section{Safety and access to neighborhoods}

Officers are responsible for notifying aggressors, witnesses, and victims about case procedures, restraining orders, and court visits, among others. However, many case procedures get delayed because police officers face several obstacles. According to a police officer, gunmen on two motorcycles stalked him while he delivered a notification in a dangerous neighborhood. A policewoman described the following:

When I arrived at the neighborhood, I soon noticed the children playing outside. I thought that perhaps the neighborhood wasn't as violent as I was told. When I went to chat with them, my colleague cautioned me that the children would snitch on us. Children were the eyes and ears of the drug dealers. They were purposefully "playing" there to guard the neighborhood from us, the police! (Officer 18, male, personal communication, December 6, 2013) 
Police officers have also been unable to answer domestic violence calls in some neighborhoods, leaving victims vulnerable to their aggressors. As an officer mentioned regarding visiting unsafe neighborhoods, "depending on the neighborhood, we might not be able to provide help, even if it is a violation of restraining order" (Officer 3, female, personal communication, September 16, 2013).

Even when they successfully enter some areas, it becomes very difficult to track the people in dispute. Many neighborhoods lack street names and housing numbers. In addition, residents are reluctant to give any information about the whereabouts of their neighbors. According to an officer, about $80 \%$ of domestic violence victims and perpetrators live in rented homes or apartments (Officer 5, male, personal communication, October 11, 2013). By the time police officers receive the paperwork, it is likely that people will have moved to new addresses. When this study's fieldwork was conducted in 2013, two of the officers interviewed were notifying individuals from cases that occurred in 2009. Cases where police officers cannot locate victims or perpetrators are closed. During my observations at police stations, only two officers asked victims to provide geographic points of reference or a physical description of the house. None of them encouraged victims to update their addresses.

\section{Factors Influencing Police Decision-Making on Cases of Domestic Violence at Women's Police Stations in Espírito Santo}

Police officers ask victims a series of questions in order to accurately assess each case.

The assessment process equips an officer with better decision-making skills, as they will decide whether they should fill out paperwork, grant her a restraining order, or start a formal investigation. This section provides examples of the various factors influencing the decisionmaking of police officers working at women's police stations, as shown in the following table: 


\begin{tabular}{|c|c|c|}
\hline \multicolumn{3}{|c|}{$\begin{array}{l}\text { COMPARISON OF FACTORS INFLUENCING DECISION-MAKING OF U.S. AND } \\
\text { BRAZILIAN POLICE OFFICERS HANDLING DOMESTIC VIOLENCE CASES }\end{array}$} \\
\hline Characteristics & BRAZILIAN POLICE & U.S. POLICE \\
\hline OFFENSE & $\begin{array}{l}\text { Injury } \\
\text { Violation of Restraining Orders } \\
\text { Witnesses }\end{array}$ & $\begin{array}{l}\text { Injury }^{1} \\
\text { Violation of Restraining Orders } \\
2\end{array}$ \\
\hline VICTIM & $\begin{array}{l}\text { History of abuse } \\
\text { Cooperation } \\
\text { Relationship status }\end{array}$ & $\begin{array}{l}\text { History of abuse } \\
\text { Cooperation }^{5} \\
\text { Fear }^{6} \\
\text { Substance abuse }^{7}\end{array}$ \\
\hline BATTERER & $\begin{array}{l}\text { Substance abuse } \\
\text { Criminal history } \\
\text { Employment }\end{array}$ & $\begin{array}{l}\text { Substance abuse }^{8} \\
\text { Criminal history } \\
\end{array}$ \\
\hline POLICE OFFICER & $\begin{array}{l}\text { Attitudes } \\
\text { Leadership }\end{array}$ & $\begin{array}{l}\text { Attitudes } \\
\text { Place }^{12} \\
\text { Training }^{13} \\
\text { Gender }^{14} \\
\text { Experience }^{15} \\
\text { Leadership }^{16}\end{array}$ \\
\hline
\end{tabular}

Table 2: Comparison of factors influencing decision-making of U.S. and Brazilian police officers.

\footnotetext{
${ }^{1}$ Logan, Walker \& Leukefeld, 2001; Buzawa \& Buzawa, 2003.

${ }^{2}$ Kane, 2000; Sorenson, \& Vittes, 2006.

${ }^{3}$ Eitle, 2005.

${ }^{4}$ Bachman \& Coker, 1995; Buzawa \& Buzawa, 2003.

${ }^{5}$ Buzawa \& Buzawa, 2003; Russell \& Light, 2006.

${ }^{6}$ Trujillo \& Ross, 2008.

${ }^{7}$ Berk \& Loseke, 1981; Ferraro, 1989; Lavoie, Jacob, Hardy, \& Martin, 1989.

${ }^{8}$ Logan, Shannon, \& Walker, 2006.

${ }^{9}$ Hirschel, Hutchinson, \& Dean, 1992.

${ }^{10}$ Buzawa \& Buzawa, 1990.

${ }^{11}$ Friday, Metzgar, \& Walters, 1991; Kemp, Norris, \& Fielding, 1992; Blackwell \&Vaughn, 2003.

${ }^{12}$ Few, 2005; Pruitt, 2008; Shuman et al. et al., 2008.

${ }^{13}$ Breci, 1989; Kemp et al., 1992; Horwitz et al., 2011.

${ }^{14}$ Stalans \& Finn, 2000; Sun, 2007.

15 Stalans \& Finn, 2006.

${ }^{16}$ Finn et al., 2004; Johnson, 2010.
} 
Police decision-making and characteristics of the offense. The literature on policing of domestic violence cases shows that injury is one of the strongest predictors of arrest (Logan, Walker \& Leukefeld, 2001; Buzawa \& Buzawa, 2003). Other predictors include use of weapons (Eitle, 2005) and violation of restraining orders (Kane, 2000; Sorenson \& Vittes, 2006). Since Maria da Penha was enacted, police stations adopted mandatory reporting procedures in cases of physical injury and mandatory arrest in cases of violation of restraining orders.

Despite these adoptions, the following is a description of three cases of physical injury, observed during this study, where police officers decided not to report. In the first case, a police officer told an injured victim to go back to the police station days later. In the second case, the police officer tries to conciliate the victim with the accused. In the third case, officers register injury cases as threat cases. This is a common procedure in one of the police stations that is located two hours away from the nearest crime lab.

Case 1: Injured victim ignored. One police station does not attend to the victim on the same day, but schedules appointments to file complaints three or four days later. It was observed that several women wanted to file charges but were rescheduled to come back another day, preferably accompanied by witnesses. Only women with severe injuries were directed to a forensic police, which had a crime lab. These women were told to go back to the police station after the evidence of injury was collected. Women who showed less severe injuries or who said they feared their partners were dismissed. None of them were provided with the possibility of requesting a restraining order. The following is a dialogue between a police officer and a victim. The victim went to the police station on Friday to file a complaint. She was scheduled for an appointment later the next week. After the weekend, she was back at the police station on Monday morning, when a female officer approached her: 
Officer 8: "You were here on Friday, right?"

Victim: "Yeah, but many things happened and I had to go home to get my son. Saturday night he [the husband] came back and hit me. I'm full of marks on my back."

Officer 8: [Hands her a small paper]: "Here, this day you come back and you must have two witnesses. If anything happens you call the police.”

Victim: "But this happened last night, around 9 PM! I called the police seven times. They arrived at midnight!"

Officer 8: "Next time you say 'he is going to kill me! He is going to kill me!'”

As observed in the dialogue, the officer dismisses the victim's right for immediate protection when she could have been provided with a restraining order. Also, the victim should be subject to a physical exam to collect evidence of physical injury. Because such evidence was not collected, it is likely that the officer will file charges as threat, if the victim returns for the scheduled appointment. Although the officer required the victim to bring witnesses, Maria da Penha Law states that victims' accounts are sufficient to start the claim.

Case 2: Officer tries to conciliate victim with batterer. During one evening, a victim walked into the police station. She was bleeding, bruised, and visibly in shock. She said she did not want to file charges fearing that her husband would kill her. The commander decided to go to her house and invited me to come along. Once at the victim's house, the husband denied the accusation. None of the neighbors were willing to act as witnesses. The husband, the couple's son, and the victim were sent back to the police station, where the husband confessed to hitting 
his wife because he caught her cheating on him with a neighbor. During the interrogation, the accused requested water to take his medicine, a handful of pills including drugs for heart disease, high blood pressure, and antidepressants. The commander expressed shock at the large amount of drugs. The victim added that the husband is addicted to alcohol and his burst was probably triggered because he took those drugs while inebriated. She added that such incidents became common after he abandoned his faith and closed down the small church he had built in their front yard. Now the church building was a bar and, once a pastor, now he had become the only client at the bar. After listening to all the stories, the commander encouraged the husband, son, and victim to sign a document where they committed to maintain peace and harmony in the family. All were dismissed after signing the agreement. According to the commander, the man was not arrested because "it wasn't a flagrante delicto and it was better for the family to have a reconciliation" (Officer 7, female, personal communication, October 9, 2013). According to the law, the victim should have been sent to the forensic police for the collection of evidence of physical injury (Brasil, 2006). The accused should have been notified to go to the police station, where he would give his version of the story. Under these circumstances, officers make copies of the documents and send them respectively to the court, the prosecutor's office, the public defender's office, and the police superintendent's office.

Case 3: Injury case registered as threat. One of the police stations started registering cases of physical injury as threats because police officers could not collect evidence of the injury. Victims with physical injuries have to travel for approximately two hours in order to obtain a report of physical injury at the capital's crime lab. Many victims cannot afford the bus fair or to miss work and often agree to register the physical injury as crime of threat. In the past, some victims were able to obtain a medical report from the local public hospital. The report from the 
emergency room worked as evidence. However, for over a year physicians denied this type of service to domestic violence victims. Until recently, hospitals were not required to notify the police when they received victims of domestic violence, nor orient victims to seek police assistance. According to the law, the police are responsible for ensuring the collection of evidence and access to a hospital, health clinic, or crime lab.

Regarding the violation of restraining orders, police have successfully implemented mandatory arrest procedures in most cases. The few cases where police were not able to arrest perpetrators were because they lived in certain neighborhoods controlled by drug dealers. As mentioned above, police officers have not been able to answer calls from areas considered dangerous and inaccessible. Finally, previous research found that use of a weapon in domestic violence was an influence in police decision-making (Eitle, 2005). In Espírito Santo, however, none of the police officers mentioned it during interviews or asked victims during hearings at police stations. Instead, in $10 \%$ of the cases observed during this study, the police officer asked if anyone had witnessed the case or who had called the police.

Police decision-making and characteristics of the victim. Studies have found that police decision-making in domestic violence cases is influenced by victim's level of fear (Trujillo \& Ross, 2008) history of prior abuse (Bachman \& Coker, 1995; Buzawa \& Buzawa, 2003), use of alcohol or drugs (Berk \& Loseke, 1981; Ferraro, 1989; Lavoie, Jacob, Hardy, \& Martin, 1989), and cooperation with police officers (Buzawa \& Buzawa, 2003; Russell \& Light, 2006).

During interactions with victims in women's police stations in Espírito Santo, none of the police officers asked questions about the victim's level of fear or use of drugs or alcohol. In $70 \%$ of cases, the police officer asked if the victim had been injured before. However, when victims 
reported their past history of abuse, officers usually asked why they remained in the abusive relationship or did not seek help earlier, as described by this female officer:

I ask them "what made you come here today, if he is beating you for three months?" They say it is because they finally took courage, but it is all lies. I learned how to read people. The truth is that they [the victims] found out he has another woman. I might be wrong. Yeah, the law was supposed to bring isonomy, but it doesn't because women are as violent as the men (Officer 8, female, personal communication, October 7, 2013). The following dialogue between a victim and a female police officer further illustrates this dynamic. In this instance, the officer is seeking information about the victim's history with her batterer, but ends up blaming her in the process:

Officer 20: "What happened?"

Victim: "When he drinks, he abuses me verbally."

Officer 20: "Why didn’t you leave him?"

Victim: "Once I filed a complaint, but I retracted."

Officer 20: “Then what?"

Victim: "I did not follow up."

Officer 20: "You see, you shouldn't have done that. You call the police, you go back to this abusive guy, and now call the police again?"

In another police station, a female officer assessing a victim's history with the accused similarly ended up putting some blame on the victim, as this dialogue suggests:

Officer 7: "Have you been here before?" 
Victim: "No."

Officer 7: "What happened?"

Victim: "We were fighting at home and I called the police, but they said they could not get in the house because he [her husband] did not beat me."

Officer 7: "Do you have children?"

Victim: "No."

Officer 7: "Do you live with him or he lives with you?"

Victim: "He lives with me."

Officer 7: “Oh, I see, you like taking care of man, huh?"

Victim: [looks down in silence]

Officer 7: "The house. Is it yours or you pay rent?"

Victim: "Rent."

Officer 7: "Who pays?"

Victim: "I do."

Officer 7: "Did he beat you?"

Victim: "No."

Officer 7: "There is nothing we can do." 
Victim: "He said I'll soon be in hell. He came running after me, jumped
the gate, and entered in the house."

Officer 7: "Did you call the police again after that?"

Victim: 'No. I moved to my mom's house, but I want to go back to my house. What should I do?"

Officer 7: "Where does he work?"

Victim: "I don’t know."

Officer 7: "Does he drink or use drugs?"

Victim: "He drinks."

Officer 7: "Where does he usually go?"

Victim: "I don’t know."

Officer 7: "If you don’t know where he stays, how would I?"

Victim: "And how am I going back home?"

Officer 7: "The house is yours. I just suggest you don’t go by yourself."

Another important factor that influences officers'decision-making is victim's cooperation. In $30 \%$ of the cases, police officers asked victims if they wanted the abuser to be arrested. During this study's interviews, police officers were asked what usually helps or derails the continuation or pursuance of cases after they had been reported to the police stations. As one respondent put it, "it helps if she is willing to speak and also to listen to what we have to offer as help" (Officer 16, female, personal communication, December 6, 2013). Two respondents said 
that the lack of victim's cooperation can impede the progression of a case, either "When the victim is too nervous or cries too much" or "wants to protect him; she asks the restraining order and then goes back to him" (Officer 11, male, \& Officer 12, female, personal communication, October 15, 2013). Other officers mentioned that it is disturbing or discouraging when a victim is reluctant to listen to police advice, such as the "rich lady who came the other day, who acted like she knew everything" (Officer 1, female, personal communication, July 26, 2013). According to officers, it is also disturbing and worrying when a victim is influenced by somebody else to go to the police, when the victim apparently does not want to file charges but does it because a friend or relative persuaded her (Officer 19, male, personal communication, July 25, 2013).

In sum, the dialogues presented above further show that police officers are concerned about the status of the relationship between the victim and the aggressor. In $55 \%$ of the cases, police officers asked questions including marital status, how long they were together and separated, if they had children together, and who owned the house or paid rent. Many officers are keen to assess whether a victim's real intent is to seek help and justice in a case of domestic violence, or is to damage the accused's reputation in future divorce and judicial disputes related to their properties or child custody. As an officer suggested, "many women use the system to take revenge on men" (Officer 8, female, personal communication, October 11, 2013). Generally, depending on how officers perceive victims, they will evaluate whether they should fill out paperwork, grant victims restraining orders, or start an investigation. If they are not sure about how legitimate a case is, they will often ask questions not related to the case.

Police decision-making and characteristics of the batterer. Previous studies suggest that three factors mainly influence police in decision-making: batterer's substance abuse (Logan, Shannon, \& Walker, 2006), history of violence (Hirschel, Hutchinson, \& Dean, 1992), and lack 
of respect toward officers (Buzawa \& Buzawa, 1990). Some of these factors seem to influence police in Espírito Santo. At women's police stations in Espírito Santo, police officers often asked victims if the accused used drugs or alcohol. When respondents were asked to describe the characteristics of a typical domestic violence case, $90 \%$ mentioned intoxication as a major triggering factor. One officer believes that "in at least $60 \%$ of the cases the aggressor makes use of these substances" (Officer 6, female, personal communication, December 9, 2013). History of violence is usually assessed during the victim's testimony. This study could not verify whether lack of respect toward officers was a factor of influence, given the limited number cases of interactions between police officers and batterers that were observed. Finally, police officers find it relevant to ask victims about the batterer's employment status. In $25 \%$ of the cases, officers asked victims if the accused was working at the time.

Police and attitudes towards cases of domestic violence. Researchers have found that police officers hold generalized assumptions about domestic violence cases (Friday, Metzgar, \& Walters, 1991), show reluctance to work with such cases (Kemp, Norris, \& Fielding, 1992), and suggest that victims are to blame for the occurrence of violence (Blackwell \&Vaughn, 2003). In this study, when asked what caused domestic violence, $70 \%$ of the respondents believed it was cultural attitudes regarding gender roles. One officer, for example, said that machismo causes domestic violence in Brazil because "men think women are their property" and "women think men will change" (Officer 2, female, personal communication, August 5, 2013). Other officers agreed, noting that machismo "was a historic problem in Brazilian society," which is "very common when women are financially dependent on men" (Officer 15, male, personal communication, December 6, 2013). However, another $20 \%$ of respondents believed that drugs and emotional instability caused domestic violence. As one officer suggested, domestic violence 
results from "a blend of jealousy, revenge, anger, addictions, crack, bad parenting, and abusive childhood" (Officer 13, male, personal communication, October 15, 2013).

Moreover, approximately $80 \%$ of interviewees believed that domestic violence cases should be brought to police attention only as a last resort. A commander said that criminal law was the worst way to deal with domestic violence (Officer 6, female, personal communication, December 9, 2013). Another added that there should be ways of addressing family needs before letting it escalate to violence (Officer 1, female, personal communication, September 16, 2013). Another suggested that a victim's wishes should be respected in cases of minor physical injuries (Officer 3, female, personal communication, September 16, 2013). Others suggested the reestablishment of conciliation in police stations, where individuals would learn how to engage in respectful disagreement, since people "simply do not know how to talk. They are incapable of establishing a dialogue" (Officer 2, personal communication, September 17, 2013). , Many officers believed that victims preferred the conciliatory approach. According to an officer, "many victims come here asking us to talk to him, you know what I mean, to scare him, but now we can't do that. It is jail, and most [victims] don't want that" (Officer 8, female, personal communication, October 11, 2013).

Many officers, including the one immediately quoted above, believed that there should be a different approach in cases where there is evidence of alcoholism or drug use. Although some officers agreed with the current policy of conciliation, they also emphasized the need for better services, where social workers should follow up with victims after they leave a police station (Officer 14, female, personal communication, October 14, 2013). One officer, for example, emphasized why such services are necessary: "After victims file their complaints they ask me 'what now? How am I going to live?' We work on the crime, but we know nothing about what 
happens next in their life" (Officer 14, female, personal communication, October 14, 2013). In agreement, another officer stated that:

It is worthy counseling the victim or the aggressor, so we don't have one more criminal case. We talk about self-esteem, we give them support, and we cheer them up, give understanding to the couple. In this one case, at first she wanted to blame him for everything, but after talking we can calm things down between them. Sometimes we give a heads up. It is not to scare him, but an alert and everything else will fall into place. I remember one case that they left here and he was even taking her for lunch. The anger in their eyes was just vanishing. They realized they did not need to reach to that point on violence (Officer 2, female, personal communication, August 14, 2013). Many police officers have also suggested that victims cause men to assault them. According to one officer, "Perhaps there would be less cases if women were less provoking" (Officer 3, female, personal communication, September 15, 2013). The following dialogue between a female commander and a fellow female police officer also clearly illustrates this assumption:

Officer 20: "Did you know that Carlos [accused] was arrested?"

Commander: "Oh, I bet she [the victim] provoked him!"

Officer 20: "Not really, the police caught him chasing her with a knife."

Commander: "But I bet it wasn't for no reason."

Officer 20: "Well, she was with the new boyfriend [laughter], the nurse from the hospital where she was treating the injuries." 
Commander: "You see! The poor man can't deal with that! It hasn't been even three months since they broke up and she finds another one! She is quick!"

Surprisingly, as evident in the dialogue below, even when a victim tries to reclaim her status of victim, her words are often dismissed by an officer, in this case a female officer:

Officer 3: [Shouts from her office]: "Bring the crying lady here!"

Victim: [Cringing and looking embarrassed]: "I can't believe this is how I'm treated here, from all places!”

Officer 3 "But weren't you crying?"

Victim: "Yes, but I'm a victim here, a woman! You are treating me this way because you've never been through what it is going on with me, have you?"

Officer 3: "No, because I know better."

Victim: [Doesn't reply and lowers her head]

According to another female officer, many victims come crying and "at first, we feel so sorry for them, but then we hear the other side of the story" (Officer 8, female, personal communication, October 7, 2013). Commenting on these behaviors, an officer describes how he did not always believe a victim:

A victim came crying and showing me all her prescriptions, wanting me to feel sorry for her, but I didn't react. I just told her she is pretty, strong, intelligent, she is everything but sick. There are people who want me to fall for their stories. I don't. I don't even know if 
there is such a thing as a victim. In my opinion, the woman is a victim of herself. (Officer 9, male, personal communication, October 10, 2013)

As this quote demonstrates, victims were often perceived as emotionally unstable or manipulative. Officers believed that victims who appear emotionally unstable do not know what they want, or like being beaten by their partners, as this quote from an officer referring to policevictim encounters at the station suggests, "She explodes, letting out everything that she has been suffering for years," or "seeks the police in the heat of the moment, when she is desperate, hurt, and full of bruises. Then, next day she comes back asking to drop the charges" (Officer 12, female, personal communication, October 17, 2013). Other officers echoed these sentiments: Many times we need to arrest them [the aggressor], and then they [the victims] cry. Once one of them ran away, thinking that if she isn't notified he wouldn't be arrested. How do they go back to these men? (Officer 8, female, personal communication, October 9, 2013) Given these sentiments, it is not surprising that approximately $60 \%$ of the police officers interviewed believe that many victims are manipulative. As mentioned before, this assumption is one of the reasons why police officers investigate the statuses of relationships between victims and the accused. Moreover, many police officers believe that women take advantage of the women's police stations. According to a commander, "most women that come here know the tricks of the law and use it to scare the man. When she says that he is a good man, but changes when he drinks, I know that she will continue with him" (Officer 3, female, personal communication, July 26, 2013). In this case, officers scrutinize women's intentions in order to verify which case is legitimate. According to an officer:

It is difficult to know [which case is legitimate] because it is a psychological work, but I look for coherence between what she says and what the witnesses say. But in many cases 
it is complicated because there are no witnesses. But where there's smoke, there's fire.

Even with lies there is a hint of truth. (Officer 5, male, personal communication, October $8,2013)$

Another officer expressed his belief that illegitimate victims often "demonize the guy, saying that he is a bad husband, uses drugs, and destroys everything in the house" (Officer 17, female, personal communication, December 7, 2013). According to this officer, these comments indicate that she wants to divorce him because "she is fed up and wants to get rid of him using the police and Maria Da Penha Law." Thus, as the officer concluded, "If she [victim] says that she just wants to scare him, it is likely that it will be just a waste of time. If she says she is afraid of him, then the case is legitimate because of the fear component" (Officer 17, female, personal communication, December 7, 2013). According to another officer, a legitimate case has to be "gender-related," which applies in instances when "he hits her because she is woman, let's say, because of machismo, because the house is dirty and he thinks she should clean it" (Officer 16, female, personal communication, December 7, 2013).

In another interview, an officer provided another example of what he considered a "legitimate" case:

I had a perfect domestic violence case last week. He hit her because she wanted to work. Her mother would watch the children while she was at work, but he said that his woman is not allowed to work. (Officer 15, male, personal communication, December 6, 2013) Police officers, regardless of gender, perceive men differently. Male perpetrators are often perceived as the real victim, who excessively reacted to a woman's provocation and were unjustly framed. After an officer consoled a victim who was beaten by the husband, she suggested that the victim go to a psychologist and invite the husband, because "after all, we have 
to understand his context, where he is coming from, this poor man" (Officer 2, personal communication, September 17, 2013). In agreement, a commander explains that:

I don't know how the judge sees it, but I think we should consider the man's perspective. I see that many women, many women [repeats and speaks louder the second time] provoke, provoke, and the men react. Men are more violent, brutal, and once she provokes, he will become violent. Unless she has PMS, she starts being violent and he can no longer control himself. She starts, slaps him on the face and he smacks her down. (Officer 7, female, personal communication, October 11, 2013)

Kemp, Norris, \& Fielding, (1992) confirm that many officers see domestic violence incidents as the fault of a victim. In sum, in Espírito Santo, officers have the mentality that a woman is at fault if she is in a domestic violence situation either because she provoked him, or let the violence escalate over time, as described by another commander:

It reaches a point where the women can't take no more, she deals with his mistakes, his wrongdoings, lack of care, alcoholism, drug use that destroys the home, and it all drains her. When she can no longer deal with that, she comes to the police station to file charges on something that was the last straw. But it is a cancer, making it very difficult to restore that family, because things went wrong a long time ago, while she remained in the relationship for self-interest, or to keep the family united, or whatever the reason. Few are the ones who say I don't accept this. (Officer 1, female, personal communication, August $13,2013)$

In conclusion of this section, police officers and commanders in Espírito Santo generally believe that it is a woman's fault to remain in a situation of domestic violence. Officers also put blame on a victim for being involved with men who have a history of substance abuse. 
Additionally, officers tend to perceive men as the real victims. When men are not perceived as victims, they are dismissed as drunkards or drug users; in other words, their violent behavior was triggered by drug consumption.

Police decision-making and place. Based on previous studies, police officers assumed that rural areas had less incidences of domestic violence (Pruitt, 2008). Nevertheless, recent studies show that rural areas have similar or higher criminality rates compared to urban areas (Pruitt, 2008; Shuman et al. et al., 2008). Women in rural areas are in greater risk due to geographical isolation, lack of police access, lack of appropriate health care, higher number of guns, and higher susceptibility to social rejection (Pruitt, 2008; Shuman et al., 2008). Victims from rural areas are more likely to consider the police sexist and racist, and less likely to seek police protection (Few, 2005).

In Espírito Santo, the majority of interviewees seemed knowledgeable about the status of domestic violence in the countryside, referring to aspects of geographical isolation, social rejection and financial dependence. A commander of a police station located in a rural area described her experience this way:

Although there were several cases of rape and sexual assault, these cases were brought to the police's attention by the teachers of public schools. There were several occasions that the commander caught men on act, raping someone in the house, but the women did not leave him. They are very dependent on them [the men], financially, and they are not allowed to work. (Officer 14, female, personal communication, October 17, 2013) Another commander had similar observations about the issue of less reporting of criminal behavior in the countryside, and pointed to differences regarding the way rural populations interacts with police, as opposed to those in urban areas: 
The first impression you have is that there are fewer crimes, but in reality there are too many cases of sexual assault, especially against younger women and minors. However, people are different. They are more respectful of the police. Even the men who are accused of crimes are more respectful. Maybe because of that there is less recidivism, because people feel very humiliated when they walk in a police station. In the capital it doesn't mean anything to be called at the police station. We see the same victim going back many times with a new husband. Here we see people only once. (Officer 12, female, personal communication, October 15, 2013)

Considering that most police stations are located in urban areas, victims from rural and impoverished communities that lack women's police stations, and are in greater risk of victimization. A city official from Jerônimo Monteiro, a municipality of 10.000 habitants in the southern part of the state, explains their reality:

Here in Jerônimo Monteiro the Maria da Penha Law does not work. If a victim calls the police, police officers might take a while to go there, then they tell her to go to the police station. Cases of domestic violence go to the regular police station, the only one in town, but the commander is never there. He is responsible for two cities, so he usually stays at the other one, Alegre. The police station is open 9 AM to 5 PM, but the city doesn't provide public transportation. Most victims don't drive, don't have phone. He [the batterer] sleeps with her at night and spanks her in the morning. The neighbors hear her screaming, but don't do anything. I also think the police is afraid of arresting them. Recently they dismissed a few cases of rape. One woman filled a complaint. A few days later they found her body. Another day two women, a couple, were fighting. One was on 
the floor, her eyes bruised. The police called them women of low life and walked away. (City Official, female, personal communication, October 14, 2013).

A police commander shares about her experience visiting a house in one of these rural impoverished communities:

Many problems exist simply because too many people live together. It is almost certain that there will be chaos. When I worked in the countryside I visited a small house that had twelve people living in it; the parents, parents-in-law, and eight sons and daughters. I saw rats and cockroaches. The house was disgusting. In the meantime, all of them were arguing over what room belongs to whom. (Officer 13, male, personal communication, October 15, 2013)

In Espírito Santo, there are three relatively closed communities located in rural areas. These communities are isolated and have preserved cultural aspects that have lasted throughout generations. One is a community of African descendants, the Quilombola community. Another community is mostly made up of European descendants called Pomeranos, and the third is composed of the Native Indigenous population. With the exception of one respondent, none of the other interviewees had information about domestic violence cases in these communities. According to a police officer, both the Indigenous and Pomeranos communities are very close: Espírito Santo is violent because of a legacy from the native indigenous groups who lived here, the Tupinambás, Tamoios, and Aimorés. They were the most violent group at the time, and they are still today. Nobody has access to the reserves, not even people from the National Indian Foundation (Fundação Nacional do Indio [FUNAI]). These are our anthropological roots. The same with the Italians, who were poor, were deceived and 
became more violent over time. In Santa Tereza the Pomeranos settle their disputes with violence, with fights (Officer 15, male, personal communication, December 7, 2013).

In sum, issues of policy implementation in Espírito Santo are similar to those identified by studies conducted in the United States. Although Brazilian officers seem more knowledgeable about cases of domestic violence in rural areas, victims face similar structural obstacles such as isolation, social rejection, and lack of access to police stations, and appropriate health care.

Police decision-making and training. According to literature on police training and domestic violence, trained officers do not see themselves as mere law enforcers, but consider themselves as having a broader understanding of their role in society (Breci, 1989), and they are also less reluctant to deal with cases of domestic violence (Kemp et al., 1992). A recent study has recorded accounts of officers who emphasize the importance of training in their work routine (Horwitz et al., 2011). Unfortunately, none of the interviewees received training on how to work with cases of domestic violence. The respondents were asked how they learned how to deal with cases of domestic violence. An officer said he bought a book about the law and read it from cover to cover (Officer 19, male, personal communication, September 17, 2013). Once in a while he consults that book. Indeed, during the afternoon when he was interviewed for this study, he consulted the book when faced with a case where a transgender person wanted to file charges for physical injuries. None of the officers knew what to do and the commander was on vacation. They asked this officer to consult his book. According to the book's author, transgender individuals would only have access to the women's police station if their gender identity and gender expression match the name and sex assigned at the national identification card. Given the mismatch, the officers refused the individual service and emphasized that the police "was only for women; any other person should go to the regular police station" (Officer 19, male, personal 
communication, September 17, 2013). It is likely that this case will set a precedent for future cases, and the response to transgender individuals who seek police protection at a women's police station will become institutionalized. Since many officers apparently did not know how to proceed on the case on that particular day, many of them learned by watching how their colleagues interacted with the victims, as one of them explained:

I didn't receive any training. I learned by talking to older cops, the commander, and listening what they said to the victims. I worked in other stations before coming to the women's police station and had a general idea of the procedures, but with domestic violence it is different. For example, if it is a case of sexual abuse of a child, or woman, these cases have their own intricacies. I know that many judges and prosecutors nowadays still have many questions. Many things are still changing. (Officer 19, male, personal communication, July 25, 2013)

Perhaps if officers had received formal training on domestic violence, they would have a better understanding of the complexities of domestic violence cases and be better prepared to respond to any situation.

Police decision-making and gender. In regards to gender and police attitudes, studies have found that female officers are more likely to refer victims to shelters and provide service with higher levels of patience and sympathy (Stalans \& Finn, 2000), as well as provide more support for victims (Sun, 2007). Given that the majority of officers at women's police stations in Espírito Santo are female, it became difficult to compare their attitudes and approaches towards domestic violence cases with those of their male colleagues. There was usually one male officer for every five female officers in each woman's police station. However, based on observations made during this study, it was noted that male officers in women's police stations were as 
friendly, or sometimes more sympathetic and patient towards victims than female officers were. Indeed, the observations further revealed that female officers were highly self-conscious about their assumed gender differences when it came to working at a police station. For example, a female officer expressed resentment for having to work with a male officer because "he is a man and obviously cannot multitask" (Officer 1, female, personal communication, July 27, 2013). The male officer was further critiqued for allegedly being too legalistic and because he didn't ask the general questions about relationship statuses of victims, as his female colleagues often did. Asked why he didn't ask those particular questions, he said that, "I feel like I need to be objective. It does me no good to hear things from her past" (Officer 19, male, personal communication, September 16, 2013). A male officer from a different police station uses a similar approach. As he noted, his job is to ask questions related to the facts, and to avoid questions about the statuses of relationships between victims and batterers, and thus he only "focuses on the crime, on what it is in the law" (Officer 9, male, personal communication, October 15, 2013). Asked about his opinion about gender distribution at women's police stations, he answered:

Police stations need sensitive people, regardless of gender. The woman arrives here in shock; she is passing through a crisis and needs to be well received, to feel well. If she meets a sensitive man, she can also develop trust. (Officer 9, male, personal communication, October 15, 2013)

Police decision-making and experience. Literature indicates that officers with less experience are less likely to arrest, even in cases where evidence of injury and history of prior abuse is strong (Stalans \& Finn, 2006). In opposition to this literature, this study suggests that less experienced officers are more likely to arrest perpetrators. Approximately $40 \%$ of the 
respondents had less than five years of experience in the police force and another $40 \%$ had more than 16 years of experience. Most of the commanders fall in the latter category. The remaining $20 \%$ had years of experience ranging between six and 15 years. Based on observations in Espírito Santo, this study also suggests that officers with more experience are more reluctant to deal with cases of domestic violence. Indeed, more experienced respondents appeared to have higher levels of frustration while those with less experience seemed more willing to follow the law and instruct victims according to the legal determinants.

Police decision-making and leadership. Studies have found that the perspectives of superior officers have a greater impact in police decision-making than departmental policy (Finn et al., 2004). In a recent study, Johnson (2010) found that police officers tend to seek approval from their superiors and avoid challenging their decisions. Based on observations, this study suggests that police officers in Espírito Santo often follow the views or directives of their superiors, even when they disagree. It is likely that the hierarchical structure of police stations discourages disagreements, since career promotions depend on referrals from superiors. During interviews, only one of the respondents seemed willing to answer any questions on this subject. When asked if the service at police stations is a reflection of the leadership style of superior officers, the police officer said:

I know that both the commander and her superior do everything they can to impede victims from filing complaints. They highly encourage victims to give up and ask to close the case. Everybody knows that the service at the police stations is horrible. (Officer 11, male, personal communication, October 15, 2013) 


\section{Police Officers and Feelings about Working with Cases of Domestic Violence}

Police officers and commanders unanimously talked about their high levels of frustration towards domestic violence cases. When asked how they feel about working with cases of domestic violence, one officer responded, "It is like working in hell. Everybody is overwhelmed. We have no structure" (Officer 1, female, personal communication, July 26, 2013). Another officer paused, reflected about her answer, and shouted "It is over twenty years through the same thing. Fuck!" (Officer 2, female, personal communication, July 26, 2013). An officer with less than five years of experience confessed that:

I wish I could snap at them! Victims are a disgrace! If we were during the dictatorship we would put them on the wall. The problem is that the service is free. I wish this police station was located on the other side of town, or we could charge for doing what we do here. (Officer 12, female, personal communication, October 17, 2013)

As observed, the causes of frustration vary, ranging from work overload, stress, lack of recognition, and psychological distress. One officer considered quitting her job, because she “can't take seeing so much violence, for nothing. The poor community lost its capacity to communicate" (Officer 16, female, personal communication, December 7, 2013). Most say their frustration comes from the number of cases unsolved, not because they couldn't solve them, but because victims file charges and then goes back to their aggressors:

It is sad. We have no choice but to file charges in cases of physical injury. This woman, who just left, is currently living with the guy. She just filed charges against the husband, who lives with her! (Officer 1, female, personal communication, August 13, 2013) Another respondent describes his work as a waste of time: 
We do all we are supposed to do. We respond to the call, go in the house, get the aggressor, but then the victim doesn't do anything, he is released, and they are back together. Even when the victim files charges, the judiciary let's him out while waiting for the judicial decision. If they set bail, most of them find a way to pay and are released again. In my opinion, the aggressor should wait in prison till the final decision. (Officer 15, male, personal communication, December 6, 2013).

Another source of frustration is the lack of uniformity in procedures among the police stations. For example, an officer showed this researcher a case that just returned from the prosecutor's office, asking them to file charges against the accused in order to provide the victim with a restraining order. However, other chiefs of police, officers, and judges understand that the restraining order can be provided without the requirement of an investigation, which is initiated when a victim files charges. As an outcome of the lack of uniformity in procedures and clear guidelines, officers make greater use of discretion, sometimes contrary to the law. An officer noted how he often acts contrary to the law when he simply asks what the victims want and grants them their wish even in situations of physical injuries, where the officer knows that legally he should arrest the aggressor (Officer 11, male, personal communication, October 17, 2013). A commander agreed with this police behavior, as she said, "If she says she just want us to scare him, I just talk to him. If she wants him arrested, he goes immediately to the prison, without food" (Officer 7, female, personal communication, October 11, 2013). Another officer added that although she does what a victim asks, she "writes everything down, especially if the victim asks me to scare him. If later in the future she is killed, nobody can say we didn't do anything" (Officer 8, female, personal communication, October 11, 2013). 
Police officers have also ignored victims' claims that did not fall within the two typical crimes of threats or physical injuries. In several cases, victims said that perpetrators damaged, stole, or sold personal belongings, and yet these were not considered as constituting domestic violence by police, as illustrated by the following dialogue between a police officer and a victim:

Officer 17: "So, tell me what happened."

Victim: “He asked me for money and I said I wouldn’t give. He already owned me $\mathrm{R} \$ 500.00$ when I left the house. When I went back, he had taken many things to sell. He left a message and now keeps sending messages. He also left his workplace. Since I refused to give him more money, he started threatening me saying that he would do some shit and then commit suicide."

Officer 17: [Reading the text message] 'I'll do some shit and kill myself. I have nothing to lose. I'll become an outlaw and you'll see what will happen.'

Victim: "He keeps cursing me and controls what time I go to work and come back."

Officer 17: "Well, this is a civil crime. You have to get a lawyer and sue him in the civil court."

Victim: "But he said he will sell the house, he will remove everything from the house, but the house belongs to us! I helped him to build 
it. [Victim says while searching messages on phone] Look here, another of his messages asking for money."

Officer 17: "But lady, asking for money is no crime!"

Victim: "What about selling things from the house?"

Officer 17: "When did you separate?"

Victim: "Yesterday."

Officer 17: "Look, you need to divorce him. The judge will decide what belongs to whom."

Victim: "But he is selling everything!"

Officer 17: "Do you have the receipts?"

Victim: "Only pictures."

Officer 17: "The judge will decide. It is not here in the police status."

Victim: "So where should I go?"

Officer 17: "To the public defender's office."

Victim: [Starts crying]

According to Maria da Penha Law, any subtraction or retention of property from a victim is considered domestic violence (Brasil, 2006). The law also considers domestic violence any act of psychological violence or moral violence. Police officers tend to ignore this aspect of the law and focus on either physical injuries or threats against a victim's physical well-being. In another police station, a dialogue between a policewoman and a victim clearly reveals this assumption: 
Victim: "So he said he will break everything when I leave the house."

Officer 8: "And what do you think that we can do? How long ago did you break up?"

Victim: "Four years."

Officer 8: "Did he threaten to do something against your life?"

Victim: "Yes."

Officer 8: "What did he say?"

Victim: "That would turn my life in hell."

Officer 8: "How long were you together? Did you have children?"

Victim: "12 years. We have two boys."

Officer 8: "Did you initiate the divorce at the family court?"

Victim: "No."

Officer 8: "Well, I'll ask you some more questions just to see if there is anything else I can do to help you, so you can solve the situation about the children. The women's police station only deals with crimes against your life. Anything related to property and children cannot be solved here."

Frustration is also an indication of the psychological distress police officers face while dealing with cases of domestic violence. An officer defines her work as emotionally draining. She tries her best to keep emotional distance from everything she sees and hears, but it is 
impossible (Officer 10, female, personal communication, October 17, 2013). Another officer supports that view, as she described it:

Working here is boring because many victims just want to talk to someone about their problems, issues of relationship. I wish I would never have to work with this anymore, these social problems that have nothing to do with the police. (Officer 20, female, personal communication, September 16, 2013)

Interviewees also shared about the comments they hear from their colleagues about work frustrations. Almost unanimously, respondents said that colleagues from other jurisdictions hold a negative image about their work at the women's police station. An officer said how a colleague from another jurisdiction screamed to her that, "you are crazy to work there; you are nuts!" (Officer 10, female, personal communication, October 17, 2013). Another officer heard that "it is not worthy working at women's police stations because it is too much work" (Officer 19, male, personal communication, September 17, 2013). Nevertheless, one officer said that while she had the chance to leave, she preferred to stay. In her words, "I believe things will get better, we will have better structure, environment" (Officer 1, female, personal communication, September 17, 2013). A commander describes how she copes with such frustrations:

Somehow I'm able to keep my emotional balance, but I also get frustrated. Not because of the victims, although they will take any chance to let it out; they will cry and scream. It is hard work, but I can manage it. Not many people would be able to handle it. My colleagues feel sorry for me, but I chose to work here and I would do it for the rest of my career. For me, there is no problem! (Officer 6, female, personal communication, December 9, 2013) 
As observed, officers feel a great deal of frustration when working with cases of domestic violence. Sources of frustration include lack of structure, work overload, stress, lack of recognition of the value of their work, lack of clear guidelines about procedures, and psychological distress. This study considered some of these factors, given the impact they have on the overall mechanism of implementing the domestic violence policy. However, even if these institutional constraints are addressed, it might not affect how police officers feel about the experience of working in a women's police station. The focus here was to highlight perceptions about their feelings. Despite acknowledging their frustrations, some officers were able to develop coping mechanisms. Such officers hold on-to the belief that they chose to be in that situation.

\section{Police Perceptions about their Role in the Implementation of Domestic Violence Policy}

While some officers talk about choosing to work at women's police stations, the reality is that the majority was assigned to work there. In order to become an officer, candidates must pass an entry exam. The exam involves many tests including intellectual, psychological, and physical assessments. According to a commander, candidates can be assigned to the capital or to the remaining districts around the state depending on the candidate's position in the exams or, in some cases, their political connections (Officer 14, female, personal communication, October 16, 2013). Female candidates are more likely to be assigned to work at women's police stations regardless of their interest in working with cases of domestic violence. As mentioned before, officers do not receive any training to work at women's police stations.

Given that some officers had the choice to work with domestic violence cases, while many others were assigned and none received special training, one wonders if they would have different opinions about their role in the implementation of the Maria da Penha Law. Despite differences in background and experience, respondents had similar opinions about their role at 
women's police stations. The majority believed they have multiple roles, not only as law enforcers, but as "conciliators, psychologists, and social workers" (Officer 2, female, personal communication, July 26, 2013). According to them, "the victims come here and want to be heard" (Officer 1, female, personal communication, July 26, 2013). Providing a comprehensive description of a police officer's job at a women's police station, an officer states:

Our job is to give support of all kinds, psychological, judicial, and social, besides doing investigation. In reality it doesn't work. We have no psychologist, lawyer, social worker, no other professional to give the support they need. So the reality is very cruel, because we have to expedite things; we cannot spend time counseling, chatting with them. To make things worse, we don't have a private room to listen to them. They [the victims] get mad when I tell them they will have to tell the story in front of everybody (Officer 2, female, personal communication, August 14, 2013).

As described above, the officer recognizes that victims usually have multiple needs that are unmet by the current system. The officer also seems to suggest that the only service they can provide, investigation, is also jeopardized because of time constraints and lack of privacy. Another officer shared a similar experience:

We need to be flexible because we deal with social issues. The victim comes here appearing fragile and scared. We have to do everything! Here, we are preacher, pastor, and social worker. It is terrible, because it also causes an impact in our family (Officer 14, female, personal communication, October 17, 2013).

As observed, officers share a common view that their work at women's police stations includes a variety of roles. All of them mentioned the role of social workers, perhaps reinforcing 
the assumption that domestic violence is a broader social issue that also impacts officers emotionally.

\section{Police Perceptions about their Interaction with Other Institutions}

Police officers were asked to describe the nature of their relationship with other institutions tasked with implementing the domestic violence policy. Among the institutions that they interact daily, respondents mentioned the prosecutor's office, the specialized judicial courts on domestic violence, the media, and the forensic medical police. The assumption here is that the relationship with these institutions also has an impact on the overall implementation of the policy. Talking about the relationship with the prosecutor's office, most of the respondents believe "there is no harmony" (Officer 5, male, personal communication, December 6, 2013). As an officer elaborated:

It is better for me not to say much [laughs]. Well, the relationship is not confrontational, but professional. There is no partnership, which should exist. It is revolting. The prosecutor doesn't work, spends short period of time with cases. They know very well how to demand us what to do, but the case gets there and it gets stuck. It is as if we were the ER [emergency room]. They don't know how reality is. From all the prosecutors I know, only one of them takes things seriously; I believe it is because she is a woman. (Officer 14, female, personal communication, October 17, 2013)

Regarding the relationship with the courts, many respondents believed that "the police, prosecutor's office, and courts are three islands. There is no conversation between them" (Officer 13, male, personal communication, October 15, 2013). The same officer added:

The relationship with the judiciary is very distant. There are no visible problems, but it is distant. Women come here saying that the judge didn't sign the restraining order, they say 
they are afraid they will be killed, that never have access to the judge. (Officer 13, male, personal communication, October 15, 2013)

Officers have had a frustrating relationship with the media, which, according to them, say that they receive anonymous calls, a service that they actually do not provide. According to an officer, when people call anonymously, they refer them to the national domestic violence hotline, number 181 (Officer 1, female, personal communication, July 25, 2013). Funded by the federal government, the call center redirects calls to police patrols. However, according to a commander:

The police patrol doesn't answer the calls. They do not want to deal with cases of domestic violence. The problem with anonymous calls is that it usually is a third person making the call and the victim herself doesn't want to file charges. When we get there she says that she fell down the stairs. We are the gatekeepers. (Officer 18, male, personal communication, December 6, 2013)

Another number also used for anonymous calls is the 100 number, also provided by the federal government. Depending on the issue, the call usually goes to the government office responsible for human rights issues or the prosecutor's office, which forwards a letter to the police station asking it to start an investigation. Ideally, after receiving a call, the police patrol should take the individuals to the police station immediately. After filling a report, the case should be sent to the specialized court within 24 hours. The judge should provide restraining orders within 48 hours. However, an officer explained that "this process can easily take at least ten days" (Officer 4, male, personal communication, September 17, 2013). Another officer shared about a restraining order that took 60 days to be delivered (Officer 9, male, personal communication, October 11, 2013). 
Police and courts also experience disconnects regarding notifications. Police stations typically do not know when requests for restraining orders are approved. According to police officers from all police stations considered in this study, courts do not notify officers about approvals nor when the accused is released from prison. Surprisingly, victims are not notified either, although the law prescribes that victims be informed when aggressors are sent to prison or released from jail. Many victims still go to police stations to seek for information about the whereabouts of their aggressors, but the police database is not updated with such information. Thus, officers learn about the status of aggressors when victims inform them about the violation of a restraining order.

Police officers were also asked about the relationship between the women's police station and the forensic medical police (Departamento Médico Legal [DML]). Forensic medical police is the only institution in Brazil responsible to write forensic reports in all cases of physical injury or death, including car accidents, fights, suicides, post-mortem exams, and many other cases like domestic violence. After victims file charges at a police station, they are given another document to be delivered to the forensic police department, the DML. At the DML, a doctor takes pictures of the injuries and writes a report describing the degree of harm. The reports define the degree of the injury based on the instrument used, whether the injury was inflicted with cruelty, or involved poison, fire, explosives, or suffocation, whether it interfered in a victims' ability to operate daily activities for a period of 30 days, if it was life threatening, and caused permanent disability, or loss of a body part.

Individuals are served on a first-come, first served-basis, and service is often interrupted if there are other emergencies, such as car accidents or bodily exams of individuals entering or leaving prison. While this study was being conducted, police officers stated that victims of 
domestic violence were refused service before 12:30 PM. Many of them traveled from other parts of the state, arrived early, and waited to be seen during the afternoon. After the exam, forensic medical examiners should write a report and send them to a police station. However, police stations rarely receive those reports in a timely manner. Usually, police officers have had to personally request for them from medical examiners. Due to lack of reports, the prosecutor's office returns a case to a police station, demanding that officers attach necessary documents. Given the volume of cases that are returned with such demands, commanders interviewed said they preferred to wait on the forensic report before sending cases to courts.

Clearly, the relationship that other institutions have with women's police stations adds to the complexity of domestic violence policy implementation. In particular, the stations' relationship with the prosecutor's office, the specialized court, the media, and the forensic department impact the fluidity of the system. Importantly, the relationship impacts police officers and their decision-making process when working with cases of domestic violence.

\section{Conclusion}

This chapter described the domestic violence policy through the eyes of police officers, investigating how they saw their roles in policy implementation, and how they perceived the law, their work environment and interaction with others, and the victims and batterers they worked with. The majority of the police officers interviewed believed they exercised multiple roles when working with cases of domestic violence. They considered themselves law enforcers, conciliators, psychologists, and social workers. The officers considered their roles this way because many saw such cases a social issue that required the attention of psychologists or social workers prior to arriving at the criminal sphere. 
When asked about their opinion about Maria da Penha Law, approximately $80 \%$ of the interviewees were skeptical about its efficiency. Many were reluctant to implement it because they considered it unfair. As mentioned before, only women were eligible to press charges. Many police officers believed that men should also be eligible to press charges against women. The officers felt that many women were taking advantage of the law by falsely reporting domestic violence for unrelated reasons, such as obtaining access to a house or properties that the couple had in common. Other officers considered the law unnecessary because victims often returned to an abusive relationship, either with the same partner or a new one. They also believed that the current statistics on the number of domestic violence cases in the state was not accurate. Related to this, the officers believed that the high number of cases being reported was because the state is small and victims had easier access to many police stations than in other states in Brazil. According to them, the state should not rank the first in cases of domestic violence in the country.

Regarding institutional constraints, police officers seemed highly concerned about the physical infrastructure, the system of data gathering, and their own safety during visits to certain neighborhoods. Regarding the infrastructure, they mentioned the need for more space, staff, and equipment. Most of the police stations were established in old buildings that had small rooms with limited space that was shared between police officers, victims, and batterers. They were also concerned about troubling inconsistencies in posting of bail and the registration of cases.

Police officers reported holding feelings of frustration due to many reasons, such as workload, lack of acknowledgment, psychological stress, and sense of inefficiency. Besides these, they also reported feeling a sense of isolation due to the low levels of interaction and 
communication they had with each other and with other institutions, such as the prosecutor's office and the courts.

This chapter further showed that, echoing findings from previous studies, Brazilian police officers are also influenced by both legal and non-legal factors when working with domestic violence cases. However, the types of non-legal factors that shape decision-making differ. This study found that in regards to offense, officers took into consideration the type of injury, the violation of restraining order, and if someone witnessed the offense. In regards to the victim, officers often asked if there was a history of prior abuse, what the victim wanted to achieve, and how willing they were to cooperate. One of the questions most asked by officers was related to victims' relationship statuses. Batterers were often asked about their history of drug use or addictions, criminal activities, and employment status. This chapter also intended to show that police stations have their own organizational culture, which continues to be shaped by the daily interactions between police officers and other individuals, including victims, who visit the stations. Officers, in particular, had common attitudes and views toward victims. Although many interviewees reported a feeling of disconnect with the prosecutor's office and the courts, this study shows that officers share very similar perspectives. The perceptions of criminal justice professionals working with the courts are discussed in chapter four. 


\section{Chapter 4: Court Perspectives about Domestic Violence Policy}

Domestic violence courts were created with the enactment of the Maria da Penha Law. As mentioned in the previous chapters, this law created specialized courts that are charged with the responsibility for protecting women against domestic violence. Like the creation of domestic violence courts in the United States earlier, the establishment of special courts in Brazil resulted from a process of judicial specialization. Underlying this process was the notion that judges no longer to be seen as generalists but rather specialists. Today, Brazil has numerous specialized courts focused on various issues including the environment, drugs, traffic, digital crimes, and elder abuse. Also known as "problem-solving" courts, these courts are organized through case or judge concentration, where a group of judges or a single judge will preside over a given judicial area. Some are independent courts with their own appointed judges, while others have a system of rotation where judges are 'borrowed' or 'leased' from other courts and given a temporary assignment. Domestic violence courts in Espírito Santo, specifically, are presided by one judge, usually female, who hears all cases from a given jurisdiction. Espírito Santo has four specialized courts in domestic violence, although all of the other courts in the state have jurisdiction to decide cases of domestic violence. The focus of this chapter is thus on the dynamics of how these courts operate as a community that influences the implementation of domestic violence in myriad ways.

Accordingly, this chapter is divided in ten parts: (a) the existence of a community; (b) community culture and organizational theory; (c) law officials and their opinion about Maria da Penha Law; (d) law officials and their perceptions about institutional constraints; (e) factors influencing the decision-making of prosecutors; (f) factors influencing the decision-making of judges; (g) law officials and their opinions about working with domestic violence cases; (h) law 
officials and perceptions about their role in policy implementation; (i) law officials and perceptions about their interactions with other institutions; (j) conclusion.

Overall, interviews with judges, prosecutors and other legal professionals show that these actors in law implementation share a common perception toward domestic violence policy in Espírito Santo. This sharing of mindset regarding the policy is likely due to the fact that interviewees belong to a court community where they share values about the policy and about domestic violence in general (Eisenstein \& Jacob, 1977; Eisenstein, Flemming, \& Nardulli, 1988; Nardulli, Eisenstein, \& Flemming, 1988; Flemming, Nardulli, \& Eisenstein, 1992).

\section{The Existence of a Community}

The policing and judicial literature suggests that police officers, prosecutors, and judges have similar influences when deciding cases of domestic violence. These diverse legal actors or stakeholders are collectively influenced by factors associated with characteristics of domestic violence cases they work on. Such factors might relate to the specific characteristics of an offense, a victim, and batterer, or relate to legal actors' own attitudes, and the set of values shared with coworkers, referred in this study as community culture. These actors have also reacted toward the implementation of domestic violence policy in a similar fashion, displaying a great deal of reluctance. As elaborated in this chapter, these similarities suggest not only that these stakeholders are influenced by factors other than the law, but also they communicate their professional and personal beliefs with each other, evoking a sense of community.

According to literature, one of the strongest influences in police decision-making is police subculture; a set of values, attitudes and community culture shared by officers through socialization (Buzawa \& Buzawa, 1990; Belknap \& McCall, 1994). For example, as noted elsewhere, police officers in women's police stations in Espírito Santo are highly concerned 
about the relationship statuses of victims and their aggressors. This concern is mostly driven by officer's prejudiced view that some women complainants are not "legitimate" victims.

Prosecutors, although are more independent than other legal actors and enforcers, equally share their opinions and attitudes with other decision-makers, including the police and judges (Johnson, Sigler, \& Crowley, 1994). According to Johnson, Sigler, \& Crowley (1994), prosecutors have the privilege of being one of the most influential members of a judiciary system. As Rebovich (1996) found out, prosecutors and other criminal justice professionals often influence each other in ways that reinforce negative views toward domestic violence cases. Hartman and Belknap (2003) share this Rebovich's observation based on their study which found that 62 professionals, including judges, prosecutors, and public defenders had similar attitudes regarding cases that they dealt with. These studies strongly support the notion that a judicial system operates as a community where specific cultures are developed and reinforced through interactions between members. In line with these studies, evidence in this research indicates that Espírito Santo prosecutors hold similar opinions with each other and with police regarding many aspects of domestic violence cases. For example, like police officers, prosecutorrespondents showed a high level of reluctance in working on domestic violence cases, held prejudiced attitudes toward victims and perpetrators, and had low opinion of Maria da Penha Law. Although the majority of respondents refer to the institutions of the judiciary systems as disconnected, or existing as "three islands,", exchange of perceptions and attitudes towards domestic violence cases crosses institutional boundaries and is more fluid than what respondents revealed in the interviews.

Judges have both active and passive roles in the creation and reproduction of court legal culture. Simply put, as legal actors, judges have responsibilities that can reinforce the culture and 
yet they are also subject to its influence. The judges from domestic violence courts in Espírito Santo interact daily with police officers, defense attorneys, prosecutors, and many other criminal justice professionals. These and other legal professionals often seek judicial advice or feedback about legal or courts' norms and procedures. Observations made at court hearings attended as part of this study help illustrate these points about legal stakeholders' interactions and shared culture that define them as a community. This author was at a hearing where she witnessed a judicial clerk enter a courtroom to confirm if the presiding judge would be able to conduct a hearing at any day and time in the future. The hearing was about a case that had happened in 2011, two years earlier. The clerk intended to schedule the said hearing for a date eight months in the future. The judge responded the following:

It is counterproductive to schedule hearings eight months in advance. People forget and never appear in court, specially the victims. Women these days get married and divorced within a blink of an eye and end up forgetting what happened. They leave one man and four months later find themselves married to another. (Judge 3, female, personal communication, August 19, 2013)

The judge gave this response in the courtroom, where police officers, a defense attorney, a prosecutor, and the clerk were present. Exchanges such as this one between the judge and the court clerk, and similar remarks by others, can further reinforce the negative attitudes of domestic violence in police and courts, as observed in some studies (Camacho \& Alarid, 2008; Belknap, Hartman, \& Lippen, 2010). These exchanges and interacts often reflect or reveal the perceptions held by the involved stakeholders, individually or collectively, toward victims, defendants, and cases of domestic violence in general. Observations at 3 hearings in all of which the presiding judge failed to appear further illustrate this point. In absence of the judge, the 
prosecutor assumed multiple roles, interrogating both parties and registering the proceedings on the court books as if it were the judge who had asked the questions. In other hearings attended by the author, defense attorneys were absent even though their absence in such hearings is absolutely forbidden by the law. The absence of judges and defense attorneys in such hearings helps reinforce a judicial culture that undermines the implementation of the domestic violence policy, ultimately helping strengthen negative attitudes towards work against domestic violence and its victims.

\section{Community Culture and Organizational Theory}

Organizational theory is based on the belief that individuals' interactions ultimately form a social system (Blumberg, 1967). In the court community literature, the concept of organization theory is used to not only explain the influence of legal and extra-legal factors in decisionmaking, but also to address the exchange of values that occurs within a legal community.

Early studies of trial courts used this theoretical framework to argue that trial courts are organizations. According to the studies, trial courts constitute a social system made up of individuals who have assigned roles, share unspoken rules, and contribute to a network of influences on decision-making on matters under their consideration (Eisenstein \& Jacob, 1977; Eisenstein, Flemming, \& Nardulli, 1988; Flemming et al., 1992). As in other social systems, values and attitudes are established and internalized among members of the trial court community, resulting in an environment where individuals' behaviors, including towards their assigned roles, become constrained (Glick, 1971).

One of the first scholars to develop this approach was Blumberg (1967), who studied several criminal courts and found that the courts were functioning as bureaucracies, often abandoning traditional adversarial norms in order to cope with high workload and limited 
resources. Blumberg (1967) found that, over a period of 15 years, prosecutors decided to pleabargain over $90 \%$ of the cases because they were overwhelmed with large caseloads. The scholar called this strategy a bureaucracy because it appears to have been developed to fulfill the demands of prosecutors' coworkers rather than their clients. Blumberg's work triggered a series of studies focusing on the organization of courts and the dynamics of interaction of its participants, even though his work applied the framework more as a general concept (Jacob, 1983).

Building upon the concept of organizational theory, Heumann (1978) argued that the practice of plea-bargaining did not emerge because of high caseloads, but rather grew out of the day-to-day interactions among court actors. While Blumberg's arguments have been largely critiqued by many scholars (Mather, 1979; Feeley, 1973; Heumann, 1978), his groundbreaking organizational model remains highly influential in the field (Jacob, 1983). Eisenstein and Jacob (1977), for example, disagreed with Blumberg's argument about courts as bureaucracies, but still used the organizational framework to study courtroom workgroups and existing networks within the court environment. In their work, Felony Justice: An Organizational Analysis of Criminal Courts (1977), Eisenstein and Jacob found that court actors cooperate with each other, depending on the availability of shared resources or the amount of constraints faced by the workgroup. Members of workgroups come from different participating organizations such as prosecutor's or public defender's office and, therefore, do not have a hierarchy or work in an assembly line fashion, as seen in bureaucracies. Instead, they engage in negotiations to reach the best outcome for all. The members would likely be motivated by the demands of their organization, possibly by the amount of workload, or if they are part of workgroups with specialized caseloads. Differences in decision-making and outcomes that Eisenstein and Jacob (1977) observed from 
the courts of the three cities they studied were attributed to the types of interaction and the work dynamics existent between workgroup members. These authors found that while there were many unilateral and adversarial decisions made, the majority of the decisions were reached through negotiations, independent of the demands from the sponsoring organization.

Nardulli (1978) further advanced the organizational framework in his book The Courtroom Elite: An Organizational Perspective on Criminal Justice. He highlighted the role courtroom elites, judges, prosecutors, and defense counsels play in assigning dispositional values to cases, as influenced by their own personal interests, community expectations, or completion of work demands. The author further found that these actors were highly concerned with achieving their career goals, regardless of their client's interests.

In collaboration with Eisenstein and Flemming, Nardulli et al., 1988 investigated, qualitatively, the dynamics of interactions between many court actors, who included the courtroom elite, in nine middle-sized felony courts from Illinois, Michigan, and Pennsylvania. Their findings resulted in three book publications in which the authors developed the idea of courts as communities (Eisenstein et al., 1988; Nardulli et al., 1988; Flemming et al., 1992). In their first book, The Contours of Justice: Communities and Their Courts (1988), the authors formulated the idea of courts as communities, given the interdependencies and power dynamics existing among many court actors, including court personnel, county council representatives, and even journalists. According to the authors, these actors influence decision-making, and that outcomes vary depending mostly on the size of a jurisdiction. As such, small-sized criminal courts are less likely to be influenced by sponsoring organizations, middle-sized courts experience more influence but also tend to be more hierarchical, and large courts receive less and sporadic influence and tend to develop workgroups that are highly influential within its circles. 
Although jurisdiction size is an important factor in influencing decision-making, the authors found that some courts of the same size had widely divergent procedures and outcomes. Nevertheless, the authors could not establish that this divergence was due to the other variables investigated in their study, such as participant's attitudes and organizational characteristics. One of the prominent contributions of their study was the finding or proof that different courts have different organizational actors, operational approaches, and procedures in processing of cases.

The second book, The Tenor of Justice: Criminal Courts and the Guilty Plea Process (Nardulli, Eisenstein, \& Flemming, 1988), was a quantitative study of the factors influencing guilty pleas and trial outcomes at the individual, environmental, and contextual level at the same courts researched in the previous study described above. In this book, the authors developed a framework for classifying court work processes and outcomes. According to the classification, individual outcomes are those influenced by characteristics, attitudes, and abilities of the internal workgroup; environmental outcomes are those related to characteristics of crime and external influences, such as media and sociopolitical contexts; and contextual attributes are those dealing with the mechanics of how things work in the court, such as clerical processing of cases, and the screening and charging of cases. Nardulli, Eisenstein, \& Flemming, (1988), found that individual attributes affected whether cases were charged or not, provided bail, or delayed. Environmental factors had little impact on case outcome, but are likely to affect some stages of case processing, such as the prosecutor's charge. Contextual attributes were vital in identifying case processing, alternative options, use of supporting agencies, and the discretionary power of actors.

The third book, The Craft of Justice: Politics and Work in Criminal Court Communities, Flemming et al., (1992) broadens the concept of court communities and introduced the 'craft' metaphor to describe how actors interact. Flemming et al. (1992) argue that courts are 
communities because actors cooperate with each other, develop interdependencies in a shared workplace, and are influenced by external political decisions. Focusing on judges, prosecutors, and defense counsel, the authors argue that the interactions among these actors influence court structure and processes. The actors' political and working craft are influenced by sponsoring organizations as well as external factors and, most importantly, by internal factors, such as the development of personal relationships.

In a different argument, Malcolm Feeley in The Process is the Punishment: Handling Cases in a Lower Criminal Court (1979) argues that criminal courts are open systems. According to the author, these courts are constantly adjusting internal and external influences, changes in policy practices, and pressures from the associated community and sponsoring organizations. Thus, it would be difficult to predict the factors influencing decisions by the courts. In a follow-up book, Court Reform on Trial: Why Simple Solutions Fail, (Feeley, 1983) concluded that many court reforms fail because of a lack of understanding regarding the complexity of court structure and proceedings, and what courts can realistically accomplish.

Further academic works have redefined the concept of organizational theory and demonstrated the influence of various factors in decision-making more clearly. In The Governance of Trial Judges Jacob (1997) showed the specific influence that the bench, as a sponsoring organization, had in the decision-making of judges. Additionally, the author established that higher levels of cooperation among judges, defined as tight coupling, reflected predictable outcomes, while low relationship ties, or loose coupling, meant more independence and thus varied unpredictable decisions. Using network analysis and maps, Baar and Baar (1977) investigated how judges interacted in the judicial system and with legislators and found that less interactions meant less funding for the system. 
Following Jacob's (1997) work, Flemming called trial courts contested terrains, where various stakeholders dispute their interests, shape how courts work, and address social conflicts (1998). Moreover, Flemming (1998) used the implementation of the Violence against Women Act (VAWA) to illustrate how internal and external stakeholders from various organizations attempted to shape the outcomes of the Law according to their ideas, interests, and institutions. The formulation of VAWA received input from various internal and external legal stakeholders such as prosecutors, defense attorneys, judges, litigants, interest groups, and community individuals. The notions of organizational theory and court community described in this section of the chapter are relevant to the understanding of the implementation of domestic violence policy. Indeed, as the court community literature suggests, we can expect that court stakeholders will not be solely influenced by law (Eisenstein et al., 1988) and decision-making is likely to be influenced by a number of factors unrelated to the case itself (Feeley, 1979; Eisenstein et al., 1988; Ulmer \& Kramer, 1998).

Adding to research on domestic violence, Lawrence Baum (2011) portrays specialized courts as a new mutation of legal courts, and argues that these courts have unique characteristics and effects. With reference to domestic violence courts in the United States, the author asserts that "of the criminal courts that were intended to change the substance of judicial policy, domestic violence courts are among those that have best lived up to that intent" (Baum, 2011, p. 130). The author attributes this success to the courts' 'therapeutic' or 'problem-solving' characteristic, which aiming at providing accountability and rehabilitation. As Baum (2011) further suggests, the unique effects, or characteristics, of this new form of legal provision include judicial monopoly, innovation in handling of procedures, and efficient bureaucratization. Baum's findings further support the argument that special courts decision-makers are active agents of 
transformation, ultimately shaping the outcomes and the implementation of domestic violence policy in general.

Thus, this transformation becomes especially possible because domestic violence cases are handled at the individual, organizational, and environmental level (Eisenstein et al., 1988). Police officers, prosecutors, judges, and their colleagues naturally develop patterns and routines at the workplace in order to maximize work efficiency (Eisenstein \& Jacob, 1977). In due time, these domestic courts actors then become repeat players who interact daily, develop networks and ties, and over a period of time, depend on each other to share views and learn to agree or disagree in the process of solving cases (Galanter, 1974). Interaction and networking also leads to the exchange of informal rules, which may vary among courts (Ulmer, 1997). Newcomers, such as attorneys, also called 'one shooter' (Galanter, 1974), will be in a better position if they interact with those repeat players, since they will quickly learn how things work in that particular court community (Kritzer \& Zemans, 1993). Players then assign meaning and values to cases, learning what "strong" or "weak" cases are and what outcome to expect (Myers \& Hagan, 1979). Finally, as Feeley recommends, "perhaps decision-making is best explained by examining the attitudes, values, and goals of the decision makers themselves" (1979, p. 152). In line with this literature, this study sought to observe the influences on decision-making at the individual and organizational levels, and to identify legal and extra-legal factors through an observation of institutional routines and possibly networks developed internally and externally within police and courts.

In sum, one of the main arguments from the literature reviewed in this section is that differences in decision-making of courts can be attributed to the existence of a community culture in the criminal justice system. The concept of organizational theory and the court 
community literature provide the theoretical bases for this argument. Organizational theory argues that individuals are influenced by several factors and are constantly exchanging values and perspectives about various issues, including their own views about their work. Thus, decision-making is best understood through an examination of attitudes, values, and goals of the decision-makers themselves (Feeley, 1979). In this study, attitudes, values, and goals of domestic violence court decision makers in Espírito Santo are examined based on respondents' experience with and perceptions of the domestic violence policy. Specifically, examined here are respondents' comments and behaviors, opinions about domestic violence law, their views on institutional constraints and factors that influence their decision-making, their feelings about working with domestic violence cases, their perceptions about their own role in implementing the law, and interactions with other involved institutions.

\section{Law Officials and Opinion about Maria da Penha Law}

As alluded to in earlier chapters, the enactment of Maria da Penha Law caused major changes on professional routines of individuals working with cases of domestic violence. Judges, prosecutors, and other court officials, who previously dismissed or ignored domestic violence cases, were now required to provide full attention to all forms of violence against women including physical, psychological, sexual, patrimonial, or moral violence. Prosecutors were required to prosecute cases of physical injury regardless of the victim's preferences and judges mandated to issue restraining orders within 48 hours (Brasil, 2006). Judges are also forbidden from sentencing alternative punishments such as community service or donation of food baskets. Instead, perpetrators should be subject to prison sentences. In addition, only the judge can authorize retraction of cases. As a result of these legal mandates, court officials were flooded 
with thousands of cases and an influx of victims, children, witnesses, and defendants. Yet, there was no increase in staffing.

Before the law was enacted, very few cases of domestic violence made it to the courts. Respondents unanimously reported that prior to the law the few cases received by the police were forwarded to the misdemeanor courts to be decided according to the law 9099/1995. As a prosecutor stated:

Before Maria da Penha Law, the case would come here only if she was severely injured. He [the aggressor] would spend the night in jail and be released on the next day. Sometimes we would call the police officer to talk to them and everything was resolved without writing the report. If the judge decided, it was probably a donation of a food basket. Hitting in women resulted in a food basket. There was no restraining order or multidisciplinary staff. (Prosecutor 7, female, personal communication, September 18, 2013)

Before the Law 9099 of 1995, domestic violence cases were decided based on the provisions of the criminal code. However, a judge described these cases "as rotten". Threats were not considered a crime, except in a few cases where the victim was severely injured" (Judge 2, male, personal communication, October 16, 2013). According to a prosecutor, domestic violence cases were "considered mere fights between husband and wife" (Prosecutor 3, female, personal communication, October 17, 2013). Respondents could not determine how many cases were heard per year. In fact, statistics about the number of domestic violence cases started being gathered after Maria da Penha Law was enacted. During a conference in 2012, the president of the Brazilian National Forum of Judges in charge of Domestic Violence Courts (Fórum de Juizes Contra a Violência), Judge Ana Cristina Silva, provided the number of cases 
that were courts in major metropolitan areas. There were 23,000 cases in Rio de Janeiro, 45,000 in Belo Horizonte, and 5,000 cases in Brasilia, the capital, and home to the smallest court (Judge Silva, A. C., female, personal communication, August 27, 2012). The creation of specialized courts and the subsequent rise in number of cases brought greater attention to cases of domestic violence. This attention contributed to the creation of statistical databases and the mapping of incidences of domestic violence across the country. In 2012, Brazil was ranked in seventh place among 87 countries, with respect to rates of domestic violence (Waiselfisz, 2012). As a confirmation of this ranking, in 2015, Brazil's President, Dilma Rousseff, announced that 15 women were being killed daily in the country ("Brazil femicide law signed by President Rousseff," 2015). The announcement was made during an event where she signed the new law, which prescribes harsher penalties for the killing of women and girls. The President believes that "the new law sends a clear message to women that the state would protect them" ("Brazil femicide law signed by President Rousseff," 2015). However, soon after its enactment there were concerns that the law would just be another legal instrument that would face challenges such as those Law 9099 of 1995 faced, including being received with reluctance by those expected to implement it. The following remarks by a prosecutor about the implementation of Maria da Penha law illustrate this point:

There was a lot of resistance. There is resistance still. There was a lot of chatting and questions about the constitutionality of the law. Everybody was watching to see if the law was going to catch. Implementation was in turmoil until these last two years. Until today, there is discrimination against cases where women are victims. (Prosecutor 4, male, personal communication, October 17, 2013) 
As Baum observed, specialized courts do not always operate in the ways legislators expected them to (Baum, 2011). This scenario was observed in one of the specialized courts in Espírito Santo, which a court official noted, until 2011, preferred deciding cases based on the law 9099/1995 instead of the Maria da Penha law. The latter encourages victims and batterers to engage in reconciliation. Furthermore, as an indication of the level of challenges facing Maria da Penha law, $62 \%$ of the respondents in this study had negative views of the law. Although, the remaining 38\% had positive views toward the law, they believed that it needed a better structure. Moreover, the majority of respondents believed that the law was either inefficient or unjust. Those who considered the law inefficient saw domestic violence as a social problem and the law was only a part of the solution. Additionally, the law was seen as inefficient because it did not do enough to end domestic violence. According to a court official, "Maria da Penha Law does nothing. If people know about the law nowadays, it is because of the media, not the courts" (Court official 3, female, personal communication, December 5, 2013). Echoing these sentiments, a prosecutor remarked that "The law would be more efficient if it prescribed more severe punishments. Punishment is extremely low. At most, three years for physical injury, one year for threat, but in both cases the courts usually grant probation" (Prosecutor 6, female, personal communication, September 3, 2013).

Respondents who believed the law is unjust argued that it goes against the constitutional principle of equality. To these respondents, the law only protects female victims of domestic violence, who can make accusations without evidence, as these remarks by a public attorney demonstrate:

Maria da Penha law was a great step for society, for women. It was an advance in many ways. However, everything has pros and cons. I have seen many injustices done to the 
defendant. It is difficult to raise his version of the facts given the victim's allegations, which have much more power. Most cases occurred inside the house. It requires a lot of attention, investigation. But suppose it is a woman with anger. Physical injury has evidence. But threats don't require evidence. What now? How will he defend himself? It is dangerous. If we look at the number of cases, the law not always is efficient. Restraining orders don't mean that it [domestic violence] won't repeat... and I've seen men being accused of things they did not do. Not to mention cases where women injure men and this law doesn't cover these cases...it ends up going to regular courts. This court should also deal with these cases. Is it rare? Yes, but only until someone opens this venue. (Public Attorney 1, male, personal communication, September 2, 2013) Three court officials share a similar perspective. According to one official, "because society is embedded in machismo, men who claim being victims of women are ridiculed" (Court official 2, male, personal communication, December 6, 2013). Thus, according to another officer, "the law should be accessible for both, men and women" (Court official 4, male, personal communication, October 16, 2013). In agreement with these views, a defense attorney lamented the law:

The law is exaggerated! The law criminalizes many types of violence, physical injury, threat, damage to properties, etc., but in my opinion, it should focus only on the physical and sexual spheres. All the other types are interpersonal. Women also are agents of moral violence, physical violence, and can also damage properties. The mainstream approach is based on machismo. But women are also aggressors. However, men do not react; they cover up, because of machismo. Men don't cry. They get hit, but his perspective is ignored. (Defense Attorney 1, male, personal communication, September 3, 2013) 
Another defense attorney with a similar viewpoint was observed explaining to a client that Maria da Penha Law: "Is similar to Labor Courts. There, the employee always wins. Here, women's words have more weight. Maria da Penha does not release! Unfortunately, the law protected the women too much" (Defense Attorney 3, male, personal communication, December 4, 2013).

As an elaboration of his remarks with a client, during the interview, the defense attorney explained the following:

They say that the victim is too protected. They are working on the law in Congress. The accused knows that the law favors the victim. It gives different treatment regarding the production of evidence. They [the clients] ask me, 'but nobody saw the aggressions, it is her word against mine? What justice is that?' The justice system pays for it, because judges cannot be excused. How is a judge supposed to decide on a case of physical injury that happened at three in the morning inside a house and nobody saw it? The police did not arrive on time and nothing was filmed nor recorded. According to the jurisprudence, what the victim said had relevant importance in the decision. Thus, sometimes, only her words, together with other facts, not proofs [said it loudly], become evidence in judicial decision-making. This is only seen at Maria da Penha Law. Not in other cases. (Defense Attorney 3, male, personal communication, December 4, 2013)

Notwithstanding these criticisms, as mentioned earlier, $38 \%$ of the respondents had positive views toward Maria da Penha law. The majority of these mentioned the law as a landmark event in Brazilian judicial history where all institutions mobilized to provide safety to women in situations of violence. A public attorney stated the "law is fantastic! It shifted domestic violence from discrimination to criminalization" (Public Attorney 2, male, personal 
communication, December 5, 2013). Many also mentioned that one of the greatest advantages of the law is the provision of restraining orders, since it immediately guarantees the protection of the victim. Finally, other respondents mentioned that the law is fair because of its overall restorative goal. According to a judge, "the objective of the law is to prevent crime and educate society. We have nothing against men. We like them. We have everything against domestic violence" (Judge 3, female, personal communication, August 19, 2013). Taking a similar stance, a prosecutor explained that:

The law does not give superpowers to women, but provides structure to end the cycle of domestic violence. A few years ago nobody would hear the cries of women. Now it provides structure not only in courts, but also in health and education. The courts take into consideration what the women say because it is a crime without witnesses. But the law prescribes public attorneys for the victim and defense attorneys for the accused. I don't think it is unfair with men. Men who don't engage in domestic violence don't need to fear. (Prosecutor 7, female, personal communication, September 18, 2013) Approximately $40 \%$ of the respondents also believe that the law should prescribe harsher punishments. The law recommends three months to 12 years in detention for crimes of physical injury, and one to six months in detention or fines in cases of threat. However, perpetrators are usually granted probation. A defense attorney argued that, "Too much time is spent in court hearings, only to grant them a few months in probation. It is never the maximum penalty. It is usually the minimum or close to it" (Defense Attorney 2, male, personal communication, October 10, 2013). A prosecutor also believed "that the high recidivism is due to lack of penalty. The process takes too long and men don't recognize the punishment" (Defense Attorney 1, male, personal communication, September 3, 2013). 
Despite these mixed views, respondents almost unanimously agreed that the lack of structure and the limited number of individuals working with cases of domestic violence in the state are a challenge to the implementation of the law. Regardless of whether they considered the law unjust, inefficient, or ideal, respondents believed that they could greatly improve the provision of services to victims if psychologists and social workers, as prescribed by the law, supported them.

\section{Law Officials and Perceptions about Institutional Constraints}

When asked about the main problems they face when handling domestic violence cases, respondents almost unanimously complained about the lack of multidisciplinary staff, the delay of court agendas, and the increased workload. The multidisciplinary staff (equipe multidisciplinar) comprises of psychologists, social workers, and lawyers. According to the law, specialized courts should be staffed with professionals specialized in legal, psychosocial, and

health issues (Brasil, 2006). The expectation of the law is that a multidisciplinary team would enhance a coordinated response to domestic violence cases, assisting judges and prosecutors and providing consultation to victims, aggressors, and their families, as well as giving special attention to children and teenagers. One of the judges protested the inadequacy of staff, "We work with what we have. There is no shelter, no psychological counseling for batterers, not even treatment for drug addicts" (Judge 7, female, personal communication, December 9, 2013). In agreement, another prosecutor added:

Many times the aggressor has issues with drugs or alcohol. Most of them are not bandits. If we had technical staff, because it is a social problem, we could solve it without touching the criminal justice system. However, there are cases that not even the law protects. Restraining orders don`t protect against psychopaths. Restraining orders won’t 
help in more serious cases. (Prosecutor 2, female, personal communication, December 4, 2013)

Although some specialized courts had psychologists, respondents argued more professionals were needed, given the unlimited agenda and increased workload. Specialized courts usually scheduled an average of five hearings per day. The courts operate between 1 PM and 5 PM, Monday through Thursday. Most of the case hearings observed during this study in 2013 concerned domestic violence incidences that had occurred in 2011 or 2012. In September 2013, new cases were being scheduled for mid-2014. One of the non-specialized courts visited during this study heard domestic violence cases only once a week. In one of them, the judge was hearing a case from 2009. Respondents believed that each court had an average of 4,000 cases. One of the specialized courts received about 1,000 new cases every month, and an average of 30 clients sought information at their front desk daily. One public defender was solely responsible for 4,800 cases. In his opinion, $85 \%$ of the cases involved clients that lived off minimum wage, which made them eligible for free public defenders (Defense Attorney 1, male, personal communication, September 3, 2013). A court official believed that workload would continue increasing during the following 15 to 20 years (Court official 2, male, personal communication, December 6, 2013). While one court official believed that the volume of cases would increase mainly due to the rise of fear among women, another court official believed that the increased media attention had an impact on their growing workload. In her opinion, "when something is out on TV, cases triple here. It is usually during the month of March, because of International Women's Day” (Court official 6, female, personal communication, September 19, 2013).

Overall, respondents believed that the high volume of domestic violence cases was due to a misuse of the legal process. The following comments provide an example of what a prosecutor 
might have considered a misuse. In this case, the victim filed charges because she believed the defendant threatened to kill her. During the hearing the prosecutor found out that the two were living together at the time the charges were filed. With a stern tone of voice, the prosecutor said to the victim:

You have to give the example. We have thousands of cases here. You are using the justice system inappropriately. Then we cannot focus on the serious cases. Espírito Santo is the state where men kill the most number of women. But because of a threat, not a physical injure, you are here. Every 100 cases that come here, five are true. But we don't have a crystal ball. People like you are not like any person; you are obstructing justice, making it so it doesn't happen because of drunkenness, because of lack of dialogue. It is thousands of cases here. Imagine how it will be by the end of the year! Our superiors monitor us day and night. Nowadays, the judicial system cannot deal with it! But we are mandated to follow the process. (Prosecutor 7, female, personal communication, September 18, 2013)

It was due cases like this that the respondents overwhelmingly believed the addition of more multidisciplinary staff would be necessary to reduce the number of cases entering the judiciary and accelerate the process. To this end, the staff would refer urgent cases to the judiciary and inform victims about the steps of the judicial process, allowing them to make conscious choices on whether to pursue their cases judicially or to seek other services, as described by this public defender:

The law needs more attention. There is a lot lacking. The multidisciplinary staff is deficient. It needs to screen cases psychologically. For how long will women take advantage of the judicial process? The TV soap operas send subliminal messages, 
teaching them to use the legal system to appropriate the house. Men say they own the house, but whatever they say is not taken into consideration. The law is here, but it is not fully applied. We need the multidisciplinary staff to filter the cases. They are the key to the process. Without their prior inspection, the judge is forced to either condemn or absolve. But domestic violence cannot be solved like that. This is a family issue that ended up in the criminal sphere. There are people being wrongfully condemned. Are text messages from a boyfriend considered domestic violence? Calling everything domestic violence won't reduce crime. We need an efficient multidisciplinary staff to mediate cases those cases that don't have physical injury. They should conduct studies and verify if there is evidence. Accounts from victims and witnesses shouldn't be the only type of evidence. (Defense Attorney 3, male, personal communication, December 4, 2013) In summation of this section, it is clear based on interviews with court officials that the officials are impeded in their work by institutional constraints, which are multifaceted. In particular, the inadequacy of support from multidisciplinary staffs, which the law requires, has led to an over accumulation of cases and has delayed the courts agenda. Although the increased volume of workload could be an outcome of greater media attention on domestic violence and victim's 'misuse' of the judicial system, it is likely that a fully operating staff of psychologists and social workers could help curb the number of cases that reach the courts. 


\section{Factors Influencing Prosecutorial Decision-Making in Specialized Domestic Violence}

\section{Courts in Espírito Santo, Brazil}

In the United States, prosecutors have been considered the least regulated body in the judicial system (Albonetti, 1987; Gershman, 1993; Dempsey, 2007). Historically, prosecutors in United States dismissed the majority of domestic violence cases (Kaci \& Tarrant, 1988). Although the adoption of mandatory arrest laws and non-drop policies caused an increase in demand and volume, charge rates remained low (Dawson \& Dinovitzer, 2001; Hirschel \& Hutchison, 2001; Ames \& Dunham, 2002; Henning \& Feder, 2005; McCord, Ross, \& Worrall, 2006). Prosecutors paid little attention to domestic violence cases and often blamed victims for the injuries they suffered (Belknap, Hartman, \& Lippen, 2010).

Similarly, prosecutors in Brazil witnessed an increase in the number of domestic violence cases after the enactment of Maria da Penha Law and the adoption of a mandatory prosecution in cases of physical injury. Although there are no studies that have documented the number of cases dismissed by courts and the duration of time taken by each case to reach conclusion, the observations in this study indicate that the treatment of domestic violence cases by courts in Brazil has similar trends as the US. Another similarity concerns what prosecutors find relevant to pay attention to when dealing with domestic violence cases. The following table shows a comparison of legal and non-legal factors taken into consideration by prosecutors when deciding what course of action to take regarding domestic violence cases: 


\begin{tabular}{|c|c|c|}
\hline \multicolumn{3}{|c|}{$\begin{array}{l}\text { COMPARISON OF FACTORS INFLUENCING DECISION-MAKING OF U.S. AND } \\
\text { BRAZILIAN PROSECUTORS WHEN HANDLING DOMESTIC VIOLENCE CASES }\end{array}$} \\
\hline Characteristics & $\begin{array}{l}\text { BRAZILIAN } \\
\text { PROSECUTOR }\end{array}$ & U.S. PROSECUTOR \\
\hline OFFENSE & $\begin{array}{l}\text { Injury } \\
\text { Witnesses } \\
\text { Motive of the offense } \\
\text { Weapon }\end{array}$ & Injury $^{17}$ \\
\hline VICTIM & $\begin{array}{l}\text { Relationship status } \\
\text { Children } \\
\text { History } \\
\text { Behavior } \\
\text { Fear } \\
\text { Cooperation }\end{array}$ & $\begin{array}{l}\text { Behavior in court }{ }^{18} \\
\text { Cooperation }^{19} \\
\text { Substance abuse } \\
\text { Promiscuity }\end{array}$ \\
\hline BATTERER & $\begin{array}{l}\text { Substance abuse } \\
\text { Criminal history } \\
\text { Behavior } \\
\text { Employment }\end{array}$ & $\begin{array}{l}\text { Substance abuse } \\
\text { Criminal history }^{23}\end{array}$ \\
\hline & & $\begin{array}{l}\text { Missed hearing }{ }^{24} \\
\text { Weapon }^{25}\end{array}$ \\
\hline PROSECUTOR & Attitudes & Attitudes ${ }^{26}$ \\
\hline
\end{tabular}

Table 3: Comparison of factors influencing decision-making of U.S. and Brazilian prosecutors.

When asked what they look for when deciding a case, prosecutors in Espírito Santo unanimously answered that they considered the facts and the law. As two prosecutors explained, it is important to "read their personality" (Prosecutor 1, male, personal communication, October

\footnotetext{
${ }^{17}$ Martin, 1994; Hirschel \& Hutchison, 2001; Henning \& Feder, 2005.

${ }^{18}$ Hartley, 2003.

${ }^{19}$ Buzawa \& Buzawa, 1996; Dawson \& Dinovitzer, 2001; White, Goldcamp, \& Campbell, 2005.

${ }^{20}$ Dunn, 2001.

${ }^{21}$ Spears \& Spohn, 1997.

${ }^{22}$ Schmidt, \& Steury, 1989.

${ }^{23}$ Martin, 1994.

${ }^{24}$ Schmidt \& Steury, 1989.

25 Martin, 1994.

${ }^{26}$ McLeod, 1983; Ellis, 1984; Cahn \& Lerman, 1991; Cahn, 1992; Ford \& Regoli, 1993; Buzawa \& Austin, 1993; Ursel, 1995; Buzawa \& Buzawa, 1996; Erez \& Belknap, 1998.
} 
10, 2013), as well as "take into consideration the history, social behavior, motive, and consequences" (Prosecutor 5, male, personal communication, October 10, 2013). According to the Brazilian Penal Code, judges are expected to consider the defendant's criminal history, social conduct, personality, motives, and circumstances, as well as the consequences of the crime, and victim's behavior (Decree-Law 2.848/1940, Art. 59). As the above quotes and information in Table 3 show, prosecutors take into consideration these and many other factors during court hearings of domestic violence cases.

Prosecutorial decision-making and characteristics of the offense. The few U.S. studies on prosecutorial decision-making are unanimous on the impact of severe injuries in the likelihood of prosecution (Martin, 1994; Hirschel \& Hutchison, 2001; Henning \& Feder, 2005). A majority of the studies have investigated prosecutors' use of interactive scenarios, where the seriousness of the offense is paired with other variables like drug abuse or possession of a weapon. In this case, the likelihood of prosecution is greater if a victim wishes for the arrest of the defendant (Hirschel \& Hutchison, 2001), if the accused has a prior history of abuse (Henning $\&$ Feder, 2005) or if the accused was under the influence of alcohol or drugs (Martin, 1994). If there are no severe injuries, neither the victim nor offender's characteristics had an impact on the decision to prosecute (Hirschel \& Hutchison, 2001). Brazilian prosecutors seem to have replicated these American prosecutorial practices as they also have considered injury the most influential factor when assessing a case of domestic violence. According respondents, questions about the type of injury and the use of weapon were asked in over $50 \%$ of the cases. However, these questions were often followed up with other questions regarding motive of the offense and witnesses. In at least $20 \%$ of these cases prosecutors asked victims why the accused attacked them. Victims usually answered that the conflict developed because the accused was under the 
influence of drugs or alcohol. In addition, prosecutors asked who saw the event or who called the police. Thus, although the law states that victims' words are sufficient for prosecution of domestic violence cases, prosecutors still saw the need to seek for collaborating evidence.

Prosecutorial decision-making and characteristics of the victim. Victim cooperation is considered the strongest factor influencing prosecutors' decision-making process on domestic violence cases (Buzawa \& Buzawa, 1996). According to Dawson and Dinovitzer (2001), when a victim agrees with the prosecution and cooperates with the investigatory process, the likelihood of prosecution is seven times higher than if a victim does not cooperate. Victim cooperation has also been linked to a decrease in recidivism rates (White, Goldcamp, \& Campbell, 2005). Investigating the likelihood of victim cooperation at 384 municipal courts, Camacho and Alarid (2008) found that it was more likely to occur when advocates first attended victims. The information and support provided at shelters and courts were highly influential in a victim's decision-making process. Studies examined the characteristics of victims who cooperated with prosecutors and found that the majority of women had children and were separated or divorced from the batterer (Goodman, Bennett, \& Dutton, 1999), suffered severe injuries (McLeod, 1983), reported prior abuse, and were issued a protective order (Kingsnorth \& Macintosh, 2004).

Some victim characteristics negatively affect the likelihood of a prosecution. Related to this, studies have found that prosecutors are less likely to prosecute cases where the victim has a history of substance abuse (Dunn, 2001) and a reputation of sexual promiscuity or a history of hitchhiking (Spears \& Spohn, 1997). Researchers explain that victim behavior and reputation is always assessed and evaluated by prosecutors, often in an attempt to establish credibility (Dunn, 2001). As such, those who do not behave in an ideal manner risk having their cases dismissed (Hartley, 2003). 
This study, in contrast to the studies discussed above in this section, found that a victim's relationship status with the aggressor and history of prior abuse were the most influential factors considered by prosecutors during court hearings. Prosecutors also took into consideration victim's behavior in order to establish her credibility. Two other important components were the victim's level of fear and level of cooperation. The victim's relationship status with the aggressor was usually one of the first questions asked by the prosecutor. In $50 \%$ of the cases, prosecutors asked if the victim and defendant were married or lived together, if the victim filed for divorce or moved out of the house, if they had children together, how long they were together, and if they had seen each other recently. Half of the victims were also asked if they had been physically injured before. In $20 \%$ of the cases, prosecutors asked questions related to the victim's behavior. Prosecutors tried to determine whether victims were good mothers, if they drank or used drugs, and if they avoided contacting the defendant, initiated the fight, or attacked the defendants. The victim' level of fear was another factor considered by prosecutors in $20 \%$ of the cases. Prosecutors often asked if victims were afraid of the defendant, if they changed their routine due to fear, or if the defendant were likely killing them. During an interview, a prosecutor explained, "that the presence of fear indicates whether the case is legitimate. It is difficult to differentiate illegitimate cases. There is a lot of revenge, victims who want them in jail" (Prosecutor 4, male, personal communication, October 17, 2013).

The following interrogation is an example of how a prosecutor assessed characteristics of the offense, the victim, and the perpetrator. It is telling that the first question was not about injuries to the victim:

Prosecutor: "What is your relationship?" 
Victim: “It's been 15 days since we've been together."

Prosecutor: 'I'll read the charges and you tell me if it is true. On September 22, 2010, the couple was in a party and started arguing; the plaintiff started punching the victim and took her cell phone; that the victim went to a public phone and called the police; the couple was together for one year, they have a daughter together, and the victim had been injured several other times. Is this true?"

Victim: "Yes."

Prosecutor: "After that, did you leave him?"

Victim: "Yes, he left the house, but I went back to him."

Prosecutor: "It wasn't the first time?"

Victim: "No."

Prosecutor: "And after that he beat you again?"

Victim: "Yes."

Prosecutor: "Why did you go back?"

Victim: "Because he changed, we have a daughter together, and I was pregnant of another. But I had a miscarriage."

Prosecutor: "How long have you been together now?"

Victim: "About 15 days." 
Prosecutor: "On this day, did you attack him?"

Victim: "Yes."

Prosecutor: "Did you hit him?"

Victim: "No. I shouted at him. Attacked with words."

Prosecutor: "Did you drink?"

Victim: "Yes, the two of us."

Prosecutor: "Do you remember where you were injured?"

Victim: "My arms and mouth."

Prosecutor: "Did you bite him?"

Victim: "No. Well, I don’t remember."

Prosecutor: [To the defendant] "Who started the fight?"

Defendant: "I did."

Prosecutor: "Because you were drunk and cursing at each other?"

Defendant: "Yes."

Prosecutor: "Did you ever attack her before?"

Defendant: "Yes, but just a few slaps."

Prosecutor: "And after that?"

Defendant: "Yes." 
Prosecutor: “Here it says you've been arrested before. What was the crime?"

Defendant: "Drug use."

Prosecutor: "Let me tell you, if you go back to this relationship, which lacks respect, something tragic will happen. It is either death or jail. Either you respect each other, or move on. I'm done with questions."

In this study, prosecutors were also asked to describe a typical domestic violence case and victim's characteristics. Studies in the United States have documented many cases where decision-makers appear to have held a stereotype of an "ideal victim" (Hartley, 2003; Dunn, 2001). Similarly, the prosecutors interviewed in this study seemed to have a stereotype of an ideal Brazilian woman victim, a stereotype they reinforced through the kinds of questions they chose to focus on while interrogating victims, as illustrated in the above dialogue. Accordingly, women who remained in abusive relationships, or fought back while being injured, risked being considered 'illegitimate' victims. Indeed, the respondents were unanimous in their description of an 'ideal' victim: someone who is helpless and without agency. A prosecutor, for example, noted that victims "are fragile, psychologically disturbed, women who were not able to regain their strengths" (Defense Attorney 1, male, personal communication, September 3, 2013). In the dialogue above, the prosecutor appears to assess if the victim fits this stereotype. The victim had to respond to the questions of why she remained in the relationship, whether she had attacked the defendant, and if she had any drug addictions. The prosecutor's focus on these questions show his determination to establish the credibility of the victim (Dunn, 2001).

Prosecutorial decision-making and characteristics of the defendant. Prosecutors also consider characteristics of defendants. Studies in the United States have showed that prosecutors are usually concerned about a defendant's history of drug use, attendance in court hearings, 
criminal history, and use of a weapon (Schmidt \& Steury, 1989; Martin, 1994). This study found that prosecutors in Espírito Santo are equally concerned about defendants' substance abuse and criminal history. In addition, prosecutors were also concerned about two other variables: the defendant's behavior as father and partner, and his employment status. In $30 \%$ of the cases, prosecutors asked if the defendant had a history of addictions to drugs or alcohol. In all these cases, both the victim and defendant confirmed that the defendant had a history of substance abuse. In $43 \%$ of the cases, prosecutors asked if defendants had been convicted of other crimes. In approximately $30 \%$ of the cases, defendants had been arrested because of drug possession or an injury causing physical attack to their spouse. In $20 \%$ of the cases, prosecutors asked if the defendant was a good husband or a good father. Finally, in $10 \%$ of the cases, defendants were asked if they were currently employed. The following dialogue shows an example of how these factors were assessed by a prosecutor during an interrogation of a victim and a defendant:

Prosecutor: [Reading the police report] 'In May 2011, the defendant set fire in a wardrobe in the house, took a knife, and said that he would kill the plaintiff. The fight started because he suspected the victim was committing adultery. The couple's son saw the fight and called his grandma.' "Did he drink that day?"

Victim: "Yes, he was drunk and used drugs."

Prosecutor: "Was he uncontrolled?"

Victim: "Yes he was [uncontrolled]."

Prosecutor: "Did he set the wardrobe on fire?" 
Victim: "Yes."

Prosecutor: "And then threatened to kill you?"

Victim: "Yes."

Prosecutor: "Then? Who called the police?"

Victim: "He jumped out of the window and disappeared. The neighbor had called the police. They searched for him and did not find him, but he came back, surrendered, and they took him to jail."

Prosecutor: "Has it happened before?"

Victim: "Fights, but not physical aggression."

Prosecutor: "Does he still use drugs?"

Victim: "Yes."

Prosecutor: "Does he work?"

Victim: "Yes, he is a mason."

Prosecutor: "How is he in the house? Is he a provider?"

Victim: "Yes, without the drugs he is a good person."

Prosecutor: "Does he continue to threaten you?"

Victim: "When he uses drugs he has hallucinations and sees me in other people's houses." 
Prosecutor: "Do you feel unsafe?"

Victim: "Certainly! My son is in the house."

Prosecutor: "Did your mom see what happened?"

Victim: "Yes."

Prosecutor: "I don't have any more questions."

Asked about the typical characteristics of defendants, prosecutors overwhelmingly indicated that most defendants of domestic violence had alcohol or drug abuse problems, problems which helped trigger the violence. According to one of the prosecutors interviewed "in most cases, defendants are addicted to drugs, usually crack. They are alcoholics but they don't recognize the addiction, and don't see themselves as law offenders. They think what they've done is normal" (Prosecutor 3, female, personal communication, October 17, 2013). This prosecutor's sentiments, as well as the interrogation dialogues documented above, demonstrate that behavioral and lifestyle characteristics of victims and defendants of domestic violence influence the decision-making of prosecutors. Indeed, prosecutors' efforts of examining extralegal attributes of victims and offenders using multiple criteria, such as questions of whether one was a good mother or good father, reflect their preconceived biased attitudes towards domestic violence cases.

Prosecutorial decision-making and attitudes toward domestic violence cases.

Literature has shown that generally prosecutors have negative perceptions toward domestic violence cases (Ellis, 1984; Cahn, 1992; Ford \& Regoli, 1993). To this end, prosecutors believe that domestic violence cases are a family matter that should not be brought to courts (McLeod, 1983; Cahn \& Lerman, 1991), and that their involvement could make things worse for the 
involved family (Buzawa \& Buzawa, 1996). Prosecutors also consider domestic violence cases difficult to work with, especially due to lack of cooperation from many victims (Ford \& Regoli, 1993; Buzawa \& Austin, 1993; Erez \& Belknap, 1998). Evidence in this study supports this literature. Most of the prosecutors interviewed for this study saw domestic violence as a broader social issue that frustrates them and which will never be solved, since it is: "cultural, historical, and tied to economic dependence, impunity, and lack of family structure" (Prosecutor 7, female, personal communication, September 18, 2013).

Overall, most respondents, including judges, believe that domestic violence is a cultural problem rooted in machismo such that "men who are cheated on believe they need to claim their honor with blood" (Judge 4, female, personal communication, September 10, 2013).

Paradoxically, many respondents did not think machismo was the main cause of the high rate of domestic violence in the state. When asked why Espírito Santo was ranked the most violent for women in the country, a judge believed it was because the "easy access to judicial institutions affects the statistics" and that "Other capitals, such as Rio de Janeiro and São Paulo, have less cases because people are busy" (Judge 6, male, personal communication, October 16, 2013). Another prosecutor questions the ranking and argued that numbers were not accurate: "We don't know where these numbers come from, not to mention that a case can be typified as a physical injury and later we see that it was just a threat" (Prosecutor 5, male, personal communication, October 10, 2013). A court official, believe "the northeastern region of the country might have a higher ranking because of poverty and machismo, but cases are not institutionalized" (Court official 1, male, personal communication, October 10, 2013).

Despite these contradictory viewpoints about the role of machismo in domestic violence, during court hearings, prosecutors often mobilized cultural understandings of gender roles to 
establish the credibility of victims and offenders. As mentioned earlier, in several instances prosecutors sought to know whether victims were good mothers or defendants good fathers. In court hearings, nearly $30 \%$ of prosecutors also asked why a victim remained in the relationship and if she attacked the defendant. This line of questioning was prosecutors' attempt to establish if a woman had 'invited' violence upon herself for behaving in ways that broke the boundaries of culturally accepted gender roles in the Brazilian society. As Ursel (1995) observes, prosecutors often criticized victims for incidences of domestic violence, especially for cases of recidivism which made it seem like the victims had not cooperated with prosecution. As a confirmation of this observation by Ursel (1995), a prosecutor expressed his frustrations working domestic violence cases this way:

Last Monday, I attended 15 people. Three or four had a history of physical injury. These are incidents that usually don't come to court. When they come, the victims change their minds. It becomes very difficult because I need her testimony. (Prosecutor 4, male, personal communication, October 17, 2013)

Indeed, half of the prosecutors interviewed in this study believed that most victims of domestic violence always went back to aggressors. In keeping with this attitude, many prosecutors considered their work with domestic violence unrewarding and frustrating:

The victim either reconciles with the batterer or finds another one that is also abusive. Punishment is worthless because the cycle of violence never ends. There was a case where a man stabbed his wife. We worked hard to arrest him, and we did it. Then, as soon as she left the hospital, she asked us to release him. I believe that in some cases, the judiciary should allow her to retract the case, but then it goes against the legislator's intent. It is frustrating. (Prosecutor 5, male, personal communication, October 10, 2013) 
Moreover, many of these prosecutors believed that part of the difficulties in dealing with domestic violence is that it is also an emotional issue, in which "people lack reasoning and externalize their jealousy and hate violently" (Prosecutor 4, male, personal communication, October 17, 2013). Emphasizing the significance of emotional attributes of domestic violence, one prosecutor elaborated that jealousy was a main culprit:

Between September 2010 and December 2011, we had 135 homicides. Causa mortis: jealousy. It is the terror that they call love. Men die because of gunfire and women because of knives. A young woman, 23 years old, was killed after a furious attack. He tortured and killed her while she was packing her suitcase. He said, "If she is not mine, she won't be anyone else's." (Prosecutor 6, female, personal communication, September 3, 2013).

In conclusion, and in line with literature, prosecutors in Espírito Santo also hold negative perceptions toward cases of domestic violence. Nevertheless, as a departure from the literature, there is no evidence that prosecutors in the state consider domestic violence a family issue that does not deserve access to courts. The negative perceptions can be attributed to stereotypes the prosecutors have of the ideal victim as a good mother, who thus conforms to traditional gender norms and the ideal batterer as a bad father, who abuses drugs and alcohol and is unemployed. Prosecutors who hold these stereotypes often disregard the complexity of domestic violence and often reinforce cultural norms of marriage or relationships by suggesting that victims are responsible for not leaving abusive relationships. Improperly understanding the reasons, or motivations behind, why victims change their minds and seek retraction of cases, prosecutors in Espírito Santo are very frustrated with domestic violence work to the point where they have very low opinions of their jobs. 
Factors Influencing Judicial Decision-Making at Specialized Domestic Violence Courts in

\section{Espírito Santo, Brazil}

Literature in judicial decision-making shows that judges have been reluctant to work with domestic violence cases (Buzawa \& Buzawa, 1996). This reluctance is attributed to the fact that domestic violence policy implementation involves a lengthy process (Leighton, 1989), involves the use of counseling programs instead of criminal procedures only (Kaci \& Tarrant, 1988), and has high dismissal rates (Belknap, Hartman, \& Lippen, 2010). It has also been established that cases of domestic violence often receive little judicial attention (Spohn, Beichner, \& DavisFrenzel, 2001) and lower punishments (Kingsnorth, Macintosh, \& Wentworth, 1999).

In its implementation, the Brazilian domestic violence policy has had similar characteristics and judges are reluctant to work on domestic violence cases as well. Historically, few domestic violence cases received judicial attention and the batterers were usually condemned to provide food baskets or community services. As noted elsewhere, these judicial practices drastically changed after the enactment of Maria da Penha Law in 2006, which created specialized domestic violence courts. Established based on a problem-solving model, the law granted judges with autonomy of operation, with an expectation that judicial productivity would rise and all of legal requirements prescribed by the law efficiently implemented. According to Baum (2011), one of the reasons why judges in problem-solving courts generally embrace judicial specialization is the satisfaction and prestige they expect to gain when presiding these courts. While in ordinary courts they may act as neutral arbiters, in problem-solving courts they have more autonomy to shape case outcomes (Carns, Hotchkin, \& Andrews, 2002; Chase and Hora, 2000). As observed in domestic violence courts in Salt Lake City, where the judges enthusiastically embraced their roles in specialized courts (Mirchandani, 2006), Brazilian judges 
also seemed enthusiastic about their roles and the mission of the court, despite their frustrations with victims and some requirements of the domestic violence law. On one hand, the law mandated the judges to evaluate cases based factors or variables prescribed by Maria da Penha Law, such as defendant's criminal history, social conduct, personality, motives, and circumstances, as well as the consequences of the crime and victim's behavior (Decree-Law 2.848/1940, Art. 59). On the other hand, the judges wondered why victims remained in abusive relationships, even after the intervention by courts. In fact, the judges acted beyond the realm of law to provide relationship advice and to assess parenting skills of victims or the defendants. Thus, this study established that judges in Brazil also take into consideration legal and non-legal factors in their decision-making. A summary of these factors comparing Brazil and the United States experiences is provided on the following page.

Judicial decision-making and characteristics of the offense. Studies have found that the degree of an injury is one of the most influential factors judges consider when determining the degree of the sentence to issue (Hartman \& Belknap, 2003; Henning \& Feder, 2005). While this finding is true in the case of Brazil's domestic violence courts, it was only in approximately $20 \%$ of the cases that a judge asked a victim to describe the type of physical injury, and to explain the reason that triggered the offense. Among other characteristics of the offense considered by judges in Espírito Santo were, the motive of the offense and the existence of witnesses. Only in $10 \%$ of the cases a judge asked a victim if anyone witnessed the offense.

Judicial decision-making and characteristics of the victim. Researchers have found that judges often consider if victims are cooperative during court proceedings in their decisionmaking (Henning \& Feder, 2005). 


\section{COMPARISON OF FACTORS INFLUENCING DECISION-MAKING OF BRAZILIAN JUDGES AND U.S. JUDGES WHEN HANDLING DOMESTIC VIOLENCE CASES}

\begin{tabular}{|c|c|c|}
\hline Characteristics & BRAZILIAN JUDGES & U.S. JUDGES \\
\hline OFFENSE & $\begin{array}{l}\text { Injury } \\
\text { Witnesses } \\
\text { Motive of the offense }\end{array}$ & Injury $^{27}$ \\
\hline VICTIM & $\begin{array}{l}\text { Relationship status } \\
\text { Children } \\
\text { Behavior } \\
\text { Fear } \\
\text { Substance abuse } \\
\text { Cooperation }\end{array}$ & $\begin{array}{l}\text { Behavior in Court } \\
28 \\
\text { Cooperation }^{29}\end{array}$ \\
\hline DEFENDANT & $\begin{array}{l}\text { Criminal history } \\
\text { Substance abuse } \\
\text { Behavior } \\
\text { Employment }\end{array}$ & $\begin{array}{l}\text { Criminal history } \\
\text { Substance abuse }^{30} \\
\text { Employment }^{32} \\
\text { Children }^{33}\end{array}$ \\
\hline JUDGE & Attitudes & $\begin{array}{l}\text { Attitudes }^{34} \\
\text { Training }^{35}\end{array}$ \\
\hline
\end{tabular}

Table 4: Comparison of factors influencing decision-making of U.S. and Brazilian judges.

Judges also take into consideration victim's behavior in court (Cassidy \& Trafimow, 2002). Cases where victims provoked the plaintiff in court received less severe sentences (Kern, Libkuman, \& Temple, 2007). In Brazil, the victim's level of cooperation was one of the least important factors considered by judges. Judges asked what victims wanted or wished to

\footnotetext{
${ }^{27}$ Hartman \& Belknap, 2003; Henning \& Feder, 2005; Fradella \& Fischer, 2010.

${ }^{28}$ Cassidy \& Trafimow, 2002; Kern, Temple, \& Libkuman, 2007.

${ }^{29}$ Henning \& Feder, 2005.

${ }^{30}$ Henning \& Feder, 2005.

${ }^{31}$ Henning \& Feder, 2005.

${ }^{32}$ Lamb \& Keon, 1995.

${ }^{33}$ Dawson \& Dinovitzer, 2001.

${ }^{34}$ Busch, 1994; Ford, Rompf, Terifaragher, \& Sherriweisenfluh, 1995; Nicolson, 1995; Goldfarb, 1996; Jenkins, 1996; Neilson, 1997; Du Mont, Miller, \& Myhr, 2003; Fradella, 2010; Hamilton, 2010.

${ }^{35}$ Crowley, Sigler, \& Johnson, 1990; Merry, 1995; Ptacek, 1999; McCue, 2008.
} 
accomplish in less than $10 \%$ of the cases. There were no comments or additional interest by the judges in cases where victims seemed unwilling to cooperate. On the contrary, one of the most important factors considered by judges was the victim's relationship status with the accused. In approximately $50 \%$ of the cases, judges asked victims if they were in a relationship with the accused at the time, if they were married, and if they had children together. Judges also sought to establish whether the victim's behavior caused the offense or she was under the influence of drugs or alcohol, if she avoided contacting the accused, and if she initiated the judicial paperwork for divorce. In $30 \%$ of the cases, judges asked if victims took measures to avoid being victimized, and in $10 \%$ of the cases victims were asked about whether or not they had a history of substance abuse. Another factor often considered by judges was the victim's level of fear. In over $20 \%$ of the cases, judges asked victims if they were afraid of their batterers, as illustrated in this dialogue in which a victim adamantly expressed her lack of fear:

Judge: "Mr. Jose was your husband?"

Victim: "Yes."

Judge: "How long were you together?"

Victim: "12 years."

Judge: "What happened?"

Victim: "We were separated for two years, living in separate houses. I wanted to keep the children but he wanted them to stay with him. The children missed school when they were with him. He said that if I didn't return them he was going to kill me." 
Prosecutor: "Did he say how he was going to kill you?"

Victim: "By stabbing or shooting."

Prosecutor: "Did he ever injure you physically?"

Victim: "Yes."

Judge: "What about the children?"

Victim: "Also."

Judge: "Do you spank your children?”

Victim: "Yes, but not like he does. He slaps them on the face, or leaves bruises on their body."

Judge: “And you?"

Victim: "I just use sandals or a small branch of a tree."

Judge: "Do you believe in what he says, that he will kill you?"

Victim: "No. I believe he says it only to scare me."

Judge: [Invites the victim's daughters into the courtroom. The children are respectively 14 (daughter A) and 12 years old (daughter B)].

Judge: [to daughter A] "You are here to provide testimony in a judicial case against your father. Are you aware of that?"

Daughter A: "Yes." 
Judge: "What did he say?"

Daughter A: "That he was going to kill her."

Judge: "Where you afraid of him?"

Daughter A: "I confronted him to protect my brothers. Sometimes he punched them, pulled their hair."

Judge: "What about your mother, was she afraid of him?"

Daughter A: "I don’t know."

Judge: [to daughter B] "Did you ever hear your father saying he was going to kill your mother?"

Daughter B: "Yes."

Judge: "Was it because she wanted you to stay with her?"

Daughter B: "I think so."

Judge: "Is he a nice dad?"

Daughter B: " "Sometimes good, sometimes bad, and aggressive."

Judge: Did he ever spank you?"

Daughter B: "Yes, slapped me on the face, pulled my hair, and punched me."

Judge: "Did you do anything wrong?" 
Daughter B: "No. He would hit us whenever it took us longer to do something he asked."

Judge: "Were you afraid of him?"

Daughter B: "Yes."

Judge: $\quad$ "How much? Too much? A little bit?"

Daughter B: "More or less.”

Judge: "Were you afraid he could hit her [the mother]?"

Daughter B: "Yes."

Judge: "Do you believe he could kill her?"

Daughter B: "Yes."

Judge: "Did he ever hit her?"

Daughter B: "Yes."

Judge: "Did she use to cry?"

Daughter B: "No.”

As evident in this dialogue, the judge insists on asking questions to gauge the victim's degree of fear of the defendant. These questions point to the judge's need to verify the victim's behavior and establish if she was a good mother or a legitimate victim, even though the victim appeared physically fragile and afraid. 
Judicial decision-making and characteristics of the defendant. Studies indicate that judges in the United States are more likely to issue harsher and lengthier decisions when defendants have a history of substance abuse and criminal behavior (Henning \& Feder, 2005), have children with their victims (Dawson \& Dinovitzer, 2001), or are unemployed (Lamb \& Keon, 1995). Judges in Brazil make decisions on cases of domestic violence similarly. Judges interviewed in this study often took into consideration the defendant's history or crime and drug use as well as his status of employment. Although judges are required by Brazilian law to investigate offenders' past criminal history, only in $56 \%$ of the cases that judges asked the accused if they had been convicted of any crime in the past. Moreover, in $47 \%$ of the cases judges asked defendants if they were under the influence of any substance at the time when they committed the offense, or if they had any history of addiction. Employment status was also considered during court hearings. In approximately $30 \%$ of the cases, judges asked defendants to provide further information about their employment. To this end, the judges asked how long defendants had been employed, the nature of relationship with their employers, and their work routine. Another important variable in the eyes of Brazilian judges was the defendant's behavior in their house. In $40 \%$ of the cases, judges asked if the defendant was a good father or a good husband, as the following dialogue in which a judge tries to investigate these characteristics, in an interrogation of a victim, demonstrates:

Judge: "Without the drugs, is he a good person?"

Victim: "He can be rude, but overall he is a good person."

Judge: "So, the problem is the drugs?"

Victim: "Yes." 
Judge: "Has he been arrested any time?"

Victim: "No."

Judge: "Is he a good father?"

Victim: [Remains in silence and nods affirmatively].

In the above case, the judge also asked one of the witnesses, a police officer, if the defendant had exhibited any aggressive behavior. The witness confirmed that the accused was aggressive to authorities in the manners he spoke to them. In the following case, the victim is a 78-year-old woman. The defendant is her son, who is 29 years old. Neighbors who had heard him breaking objects in his mother's house called the police.

Judge: "Does your son use drugs?"

Victim: "No, he just drinks. He used to drink a lot, but since he has been arrested he stopped."

Judge: "Why didn't you go to visit him in jail?"

Victim: "I didn’t know where he was."

Judge: "Do you want him to go back to the house?"

Victim: "Yes."

Judge: “Are you sure?"

Victim: "Yes."

Judge: "Does he work?" 
Victim: "Yes."

Judge: "On the day they called the police, was he drunk?"

Victim: "Very likely, because he was out for a while."

Judge: "Here it says that he wanted to divide the house and you didn't let him do it.

He became nervous, attacked you, and strangled you. Did this happen before?"

Victim: "Only two other times."

Judge: "Not counting this, is he a good son?"

Victim: "Yes."

Judge: "Why is he a good son?"

Victim: "He works and never ceases to help me."

Judge: "So, you are saying that you're sure you want him back living with you?"

Victim: "Yes, it has been three months since I last saw him."

In both cases, the judge tried to rely on the victims' perceptions about the character of the defendants and their behaviors as sons, husbands, or fathers. As pointed out earlier, defendant's quality as a father, son and husband is one of the most prominent factors considered by judges, besides his criminal history, history of substance abuse, and employment status, in their decisionmaking. 
Judicial decision-making and attitudes. Studies show that judges often have stereotyped beliefs and expectations about how victims and defendants are supposed to behave (Busch, 1994; Ford, Rompf, Faragher, \& Weisenfluh, 1995; Fradella \& Fischer, 2010). Studies have also shown that judges who have received training to work with domestic violence cases are more likely to have better interactions with victims (Merry, 1995) and hold less stereotypical views about domestic violence (Crowley, Sigler, \& Johnson, 1990). Based on their remarks made either as questions, opinions or advice, this study found that judges in Brazil have stereotypical views about domestic violence victims, and offenders (Hartman \& Belknap, 2003; Henning \& Feder, 2005). Indeed, $40 \%$ of the cases considered in this study had comments that exhibited judges' stereotypical attitudes towards victims and offenders of domestic violence. Nevertheless, none of the special court judge respondents had received any training regarding domestic violence cases. It is worth noting here that, the lack of training could perhaps explain why the judges made stereotypical and patronizing remarks to victims.

Furthermore, in many of the dialogues presented in this chapter, there are many instances where judges asked victims about their level of fear and drinking behavior. This line of questioning by judges demonstrates their stereotypical attitudes toward victims in that the judges likely consider legitimate victims to be women who are passive, feminine, heterosexual, and helpless (Nicolson, 1995; Jenkins, 1996; Hamilton, 2009). In addition, the judges' asking of the victims if they had provoked the defendants or if they cried after being threatened by the defendant brings to attention the observation in the literature, that judges expect victims to stereotypically appear as sad and psychologically traumatized (Du Mont, Miller, \& Myhr, 2003). Furthermore, in cases where victims were asked why they remained in abusive relationships, the judges demonstrated a lack knowledge regarding the complexity of abusive relationships and 
seemed to align their views with those of individuals in the society who stereotypically fail to understand why a woman would go back to an abusive relationship (Hamilton, 2009). Reflecting their ignorance, in many instances, judges suggested that the victims could easily disengage from their abusive relationships, as this judge-victim dialogue makes clear:

Judge: "Does he still fight with you?"

Victim: "He fights when he is drunk. We talked, he promised to stop drinking, but I can't stand it anymore."

Judge: "Well, commitments with people who are addicted are the same as nothing. He says he will change, but you can't believe him. In your case, you lived together for 15 years. I can't see how you can still be together."

Victim: "But it is getting too dangerous for me!"

Judge: "The problem is because he is addicted. They drink to boost the effect of the drugs and vice-versa. I'm not sure if I would have the same stamina to deal with an addict. I've seen many cases like yours here. It is difficult."

In the following case, the judge allowed the defendant to try to reconcile with the victim while in the courtroom. At first, the judge discourages the victim from remaining in the relationship. However, at the end of the hearing the judge counsels the defendant to fight for his family, suggesting that the victim would go back to him because "women are easy", drawing to attention his ignorance and prejudiced stereotypical view of domestic violence victims (Judge 4, female, personal communication, September 17, 2013):

Defendant: "Is there any chance we can reconcile?" 
Judge: "I don't believe she would go back to you. I understand that these are matters of the heart, nobody can tell you what to do, but I don't believe she would forgive you, unless you change."

Victim: "While he was in jail he stopped using drugs, because he cannot use them there, but as soon as he got out...I don't know, I don't think he would change."

Judge: "If I were you, as much as I loved him, when people are on drugs, they lose everything."

Victim: "Indeed. He lost several jobs! He could be making a lot of money today as a mason, but every time he got the money he would lose everything."

Judge: "I believe that only God; church and faith help a lot. I think that addictions belong to the devil [laughing] because people do horrible things. It is very difficult. Not even rehab can do anything, because people just get isolated and then, once released, they start using again. But faith, God, only God...

Defendant: " "I am not that guy that loses control."

Victim: "So why don't you stop?"

Judge: "Yeah, why?"

Defendant: " "It is an annoying voice in my head that bothers me."

Judge: "So, when you hear this voice just go play with your children, or work non-stop. I don't know!" 
Judge: [To the defendant] "So, see if you really change, try to get your family back, if she accepts. I know women are easy.”

Defendant: [Nods affirmatively]

Domestic violence judges also have stereotypical views about batterers. Unlike in the case of women victims, however, the stereotypical views judges have about male offenders are generally positive. According to Busch (1994), male suspects are usually viewed as good husbands who lost control over anger. In this study, this view came across in various dialogues where judges asked victims and witnesses if the defendant was a good husband, father, or son. In the following dialogue, for example, the judge tries to establish the kind of relationship that the defendant had with his family:

Judge: [Reading allegations to the victim] 'In January of 2010 the defendant entered the victim's house and hit her with an iron stick. He was drank. The victim was injured on her legs and buttocks. The victim and defendant have two daughters and a granddaughter together. They are currently separated, but live in the same lot. The victim called the police, but they refused to go to their house because it was late.' "Is this what happened?"

Victim: "Yes."

Judge: "How long have you been together?"

Victim: "15 years."

Judge: "After this, did he hit you again?" 
Victim: "No, no, no."

Judge: "Do you think he was drunk?"

Victim: "He was."

Judge: "Were you living together?"

Victim: "We were separated, but we share the same lot."

Judge: [Says with sarcastic tone] "You cannot be serious."

Victim: [Remains in silence, crosses her arms and sinks in the chair]

Judge: "What caused the fight?"

Victim: "He wanted to enter my house. I locked the door and didn't let him in. Then he broke the door and forced himself in."

Judge: “It was late, wasn’t it?”

Victim: "Yes."

Judge: [Laughing] "You see, it wasn't because he was drunk that you locked your house, but because it was late! Then what?"

Victim: "I grabbed my daughter and we left the house."

Judge: "Were you drunk, also?"

Victim: “No. I was at home. I don’t remember, maybe when I got back from work." 
Judge: "Is he a good husband?"

Victim: "Yes."

Judge: "Is he hard-working?"

Victim: "Yes."

Judge: "Is he aggressive with you?"

Victim: "Only when he drinks."

Judge: "What about now? He is more controlling, right? It is good to fight, isn't it? I read on the newspaper that it betters relationships [laughing].

Do you drink together?"

Victim: "I always drank with him; we like beer."

Judge: "Do you think it was an isolated incident? That it only happened once?"

Victim: "Yes, it was an isolated fact."

Judge: "It was the first time, wasn't it?"

Victim: "Yes, I don't think it will happen again."

Judge: "Is he a good father?"

Victim: "Yes. Good grandfather, too."

Judge: "You were too young when you got married, weren’t you?" 
Victim: "I came here before to close this case. I was even called here to say if I wanted to continue. I said to cancel everything. Why was I called again?"

Judge: $\quad$ "Hm...let’s see here."

Victim: “It took them only five minutes. I asked for a copy, but they didn't give me one."

Clerk: [To the judge] "The victim was at court in 2012, two years after the fact."

Defendant: [To the judge] "They only called me at the police station in 2012."

Judge: "Yeah, the police station is also overloaded." [The judge continued flipping the pages of the file, until she found an earlier case where the defendant was accused of threatening to kill the victim with a knife. The case had been closed.]

Judge: [To the defendant] "Were you arrested in this case?"

Defendant: "No."

Judge: "All right. You two are dismissed."

Stereotypical views about victims and defendants may reflect judges' overall attitudes towards domestic violence cases. Literature suggests that patronizing comments made by judges are examples of judicial attitudes towards cases of domestic violence (Busch, 1994; Ptacek, 1999). As evident in this study, Brazilian judges are eager to provide relationship advice to a victim, as they often assume that victims need relationship counseling and empowerment more 
than they require police and legal protection services. It is unsurprising, therefore, that judges asked more questions about the status of a victim's relationship than the type of crime committed against her. As a case in point, two courts observed in this study called victims to appear in court so as to confirm whether they desired their cases to remain open or not. Judges and prosecutors called victims in groups of five or ten to enter the courtroom. As soon as they were inside the court, the judges asked them if they wanted to withdraw their cases, and whether they remained in the relationships in question and why. Victims timidly answered the questions about the dynamics of their relationships. Interestingly, in one of the cases, the judge seemed less interested in the issue of victim's financial dependence on the accused and suggested that she could easily leave an abusive relationship:

Judge: "So, you are still together?"

Victim: "It is complicated."

Judge: "What decision are you going to make?"

Victim: "That is what I also want to know. I can't afford it."

Judge: "You were called here today to inform us if you want to continue with the case. Regarding your separation, this is the easiest thing on earth. You just need to decide who will have the kids, pay the alimony."

Victim: “But we just lived together. We don't have children. What I don't want is..." [Judge interrupts Victim]. 
Judge: "Just by being here it tells that you are unsettled. The relationship is over. In your case, without children, it should be easy to split the belongings."

Victim: "It would be easier if he left the house."

Judge: "Of course, because it is easier for the man, but sometimes this is the most difficult thing to do."

Victim: "I went back to him because he said he was going to break into the house. I'm afraid. I don't think he would kill me, but he would certainly break down the door."

Judge: "Today we are here just to ask you if you want to continue or not."

Victim: "I don’t want to see him in jail."

Judge: "Do you have a restraining order?"

Prosecutor: "She canceled it. It was canceled when you went back living together."

Judge: "We are going to keep your case open. If anything happens, go to the police station."

The above dialogue shows how the victim and judge were concerned about different issues. While the victim seems concerned about safety and financial stability, the judge was focused on the status of the relationship and the legal proceedings regarding separation and restraining orders. As observed in the literature, this type of judicial behavior ultimately puts 
women in a subordinate position, and ignores their level of fear and perceived risk of victimization (Spears \& Spohn, 1997; Kingsnorth, Macintosh, \& Wentworth, 1999).

\section{Law Officials and Feelings about Working with Domestic Violence Cases}

When asked about their opinions regarding working with domestic violence cases, the criminal justice professionals interviewed in this study revealed that they had a great deal of frustration in their job. About $80 \%$ of the interviewees considered their work unrewarding, emotionally draining, or overwhelming. For some, the frustration with work has to do with the reality that the policy they are implementing is nothing more than a political project, as one prosecutor noted: "the work is unrewarding because the policy is not real. It is to show off. It is politics. It is to render votes during elections, boost some people's egos, get media attention; it is for self-interest" (Prosecutor 3, female, personal communication, October 17, 2013). Yet for other interviewees, their work was emotionally draining due to the nature of the work as one that was new and evolving, and the sense that the work was ineffective in addressing domestic violence, as a court official described:

It is difficult not to get yourself absorbed. I feel overwhelmed. I have coworkers who say that it is just a matter of developing practice. They can forget everything once the day is over, but I think it is too heavy. It is one case after another. The cases with sexual violence are even worse; not to mention those clients who are mentally impaired. We repeat the same thing three times and they still don't understand. (Court official 6, female, personal communication, September 19, 2013)

Another court official and a public defense attorney agreed with this assessment. The court official in particular believed that $40 \%$ of the cases of domestic violence were illegitimate, while the public defender believed that the system was unfair to defendants. A court official, 
who wished he could punish the victims for going back to an abusive relationship, shared these views:

Nowadays, about $40 \%$ of the cases are unfounded. When I notify defendants to appear in court, they [the victim and the defendant] are living together. Why? They [the victims] lack self-respect. They [the victims] go to the police, the court, for what? I don't think they fear or are under the threat of domestic violence. The ones [victims] who initiated their case because of fear went back [to the defendant] even before the case was over. You ask me how I feel. [Laughing] I feel like beating them up. (Court official 5, male, personal communication, October 10, 2013)

A public defender, on the other hand, shared that his frustration with work concerned how defendants were being treated by the system put in place by the domestic violence law: The work is demanding. Men [the defendants] arrive here unable to provide evidence, powerless. They say that nothing happened, but they can't prove it. The victim's words are more powerful than forensic evidence. These are incidents that allegedly occurred inside the house. He doesn't press charges against her, because of shame or machismo, so he can't argue he was defending himself. Instead, he is seen as the villain. The law supports the women. (Defense Attorney 3, male, personal communication, December 4, 2013)

Notwithstanding these expressions of disappointments with domestic violence work, around $20 \%$ of the interviewees held positive opinions about their experiences working with domestic violence cases. As one of these interviewees, a prosecutor, explained:

It is gratifying [to work with domestic violence cases] because it is a social cause. The criminal approach is frustrating. I wish I could work more with preventive measures. It is 
good to see how much difference we make in people's lives. To restore them, empower, and develop consciousness. It is cool. I only resent the fact that the law is not well interpreted. It is misinterpreted in the police, judiciary, and executive. I often hear people saying, "Here comes the feminist." They say that I am teaching women to lie, giving them the weapon to force men to stay with them. It is absurd when I hear people saying that these are "family matters," which we should not get involved with. (Prosecutor 2, female, personal communication, December 4, 2013)

Overall, the majority of the law official interviewed shared negative opinions towards their work with domestic violence cases. The negative perceptions about work are often reinforced in the court community in ways that those few law professionals who expressed their satisfaction were sanctioned by their coworkers. Despite being sanctioned by colleagues, those who were happy about their domestic violence work, like the prosecutor quoted above, saw themselves as playing an important social role. While considering the criminal component of domestic violence work frustrating, the prosecutor believed that the work seemed rewarding when victims she advocated forgot empowered and the system promoted positive social change. It is likely that perceptions, such as this prosecutor's, about their roles in implementing domestic violence policy could influence how law professionals feel about their work in general.

\section{Law Officials and Perceptions about Their Role in Policy Implementation}

Interestingly, criminal justice professionals in domestic violence courts in Espírito Santo believe that their role is to implement a therapeutic and problem-solving judicial model. The majority of the respondents stated the importance of helping victims and defendants. However, the nuance in this statement is that the respondents saw themselves as providing a social service, not a criminal prosecution where the defendant, once proved guilty, needs to be punished. As 
Hartman \& Belknap, (2003) noted, judges, in particular, did not believe that their decision would necessary have any impact in reducing domestic violence. Often, they preferred counseling the parties and providing advice about relationship, parenting, or drug addiction, as a judge stated: We don't want to punish men, but avoid the legal process. Criminalization doesn't solve anything. Both the victim and the defendant are usually facing a lot of misery, hunger, and poverty. If he goes to jail, there is nothing he can do. I don't like issuing restraining orders. Only education and psychological treatment can help. It has to be provided to the accused. It would be really good if we could work with the inmates (Judge 7, female, personal communication, December 9, 2013).

As earlier shown, only judges chose to give relationship advice in courtrooms. In many cases, prosecutors or defense attorneys asked about the statuses of the relationships and took the opportunity to make remarks about what the victim should do. In the following courtroom interrogation, the defense attorney uses his religious views to suggest that the victim should remain in the relationship with the defendant, drawing attention to the idea that these law professionals do not see their roles in implementing domestic violence law as legalistic in dimension but rather social.

Defense Attorney: "Do you live together?"

Victim: "Yes."

Defense Attorney: "Does he currently beat you?"

Victim: [Remains silent]

Defense Attorney: "What I'm asking here is if you want to continue with him? I am Christian. We want you to continue, but did you go to the 
public defender's office to file for divorce? You know you can file for the recognition and dissolution of your civil union. Did you do it?"

Victim:

"I went to the women's police station. They told me that I shouldn't have accepted him back in the house, but because I did, I am responsible for him. She was very rude with me. They also said I could burn him."

Prosecutor: "What he is asking is if you want to stay with the defendant!"

Victim: "I already asked him to leave the house. I don't want him the way he is now."

Judge: [To the defendant] "Do you agree to leave the house?"

Defendant: "She is right, but I told her I would change."

Prosecutor: "Look, she already gave you a chance in 2011. Nobody can change anybody. Whatever it is you are saying is bullshit."

Judge: "Do you confess what you've done?"

Defendant: "I don’t remember what I did."

Judge: "Were you stoned?"

Defendant: "No, I was drunk. She knows that. If I mix drinks, I get agitated; but when I use drugs, I become sluggish.” 
Although public attorneys and defense attorneys stated that their role was to help victims and defendants, in none of the observed cases did the parties receive prior instructions about how to behave in the courtroom. The victim in the above example did not have an attorney, although the law requires that an attorney should accompany all victims and defendants. In all the court hearings observed in this study, the first encounter between the victim and the attorney provided by the state was in the courtroom. When the attorneys were present during the hearing, they reached out to the victims in only $10 \%$ of the cases. During the majority of court hearings, the attorney sat next to the victim, did not initiate any communication, and did not question the defendant when given the opportunity by the judge. When asked about his perceptions of his role in domestic violence cases, a public attorney, recently assigned to work with victims, answered that:

It is gratifying because I see how I'm being used as a tool to apply the law toward helping victims and society. I value my work and appreciate the professional maturity I gain from it. I see it as a social service. It is an important role because the victim has a lot of questions about what's going to happen about the case. It is important to instruct her. We help them go through this difficult moment and provide her with the necessary attention. (Public Attorney 1, male, personal communication, September 2, 2013) When asked about meetings or any contact with the victim prior to the court hearing, the public attorney answered:

Unfortunately, there is no way to know who they are prior to the hearing. I first meet her during the court hearing, and it is when I become aware of what happened. I realized that the first contact between the defense attorney and the defendant is in the court. In many cases it [being unable to provide legal counseling prior to the hearing] delays the 
continuation of the case. A few days ago, there was a case that we lost because she [the victim] said she did not feel threatened. (Public Attorney 1, male, personal communication, September 2, 2013)

Defense attorneys were also asked about their role and the frequency in which they are able to provide defendants with legal counseling prior to the court hearing. One of the interviewees stated the following about his role:

My role is to defend. If I don't do it well, he [the defendant] can be condemned to up to five years! There should be one defense attorney for him [the defendant] and for the victim. However, our workload is much bigger. It is the prosecutor, public defender, plus the judge wanting to put him in jail, plus the word of the victim, which has a lot of weight, all against me. I'm practically alone. (Defense Attorney 1, male, personal communication, September 3, 2013)

When asked about the provision of legal counseling prior to court hearings, another public defender stated:

We have a lot of cases! If I were to provide any counseling before the hearing... [Holding both hands in the air and shakes his head, followed by a long pause] I try to collect all evidence in court, during the hearings. I have to think fast. When I have a chance, I just say what are his [the defendant's] rights and his options, if he prefers to confess or deny what happened. If he asks my opinion I say what I think, as long as we have evidence. (Defense Attorney 3, male, personal communication, December 4, 2013) In summation, the majority of the law-professional respondents saw their role as therapeutic, as providing a social service to victims and defendants. This view was evident in the large number of court hearings where judges, prosecutors and defense attorneys asked an array 
of questions about the relationship status of the victim and the defendant, and the amount of advice each of them offered the disputing parties about how they could proceed with their cases. Although respondents seemed skeptical about the impact of their work on reducing cases of domestic violence, interviewees were optimistic that the dialogues made during the court hearings were helpful to both victims and defendants. By engaging in open conversations in courtrooms, featuring judges, prosecutors, and defense attorneys, and disputing parties, these law professionals believed that they provided an important social role, where the parties could find resolution regarding their abusive relationships. Yet, while much emphasis was given to the attempts to restore the relationships, little attention was given to legal counseling that victims and defendants desperately needed.

\section{Law Officials and Perceptions about Interactions with Other Institutions}

Interviews with law officials offered little in the way of shedding light on their interactions with other institutions involved in the implementation of the domestic violence law. Nevertheless, overall, the interviewees reported that they had a positive relationship with the police, the prosecutor's office, the office of the defense attorneys, and the courts. The majority of the interviewees considered the legal process adequate and that it moved at the right pace. One prosecutor believed that the institutional system implementing the law was effective because "the police is credible and well trained, they provide immediate support when called by the victim." A judge also acknowledged the work provided by the police, and believed that the police "were present in $95 \%$ of the times when they were called." Interestingly, as earlier noted in this study, police officers expressed statements of disappointment regarding their interactions with the courts. For example, police officers wished to be notified by the courts when judges issued restraining orders or released aggressors. Other institutional problems involved the discontent 
regarding decisions made the State Supreme Court, which often ignored the opinions of lowerlevel bureaucrats. Decisions by the State Supreme Court could have influences on the creation and allocation and the staffing of specialized courts. It is likely that, aware of the highly politicized nature of these decisions, the law professionals interviewed in this study shied away from expressing their frustrations with the special court institutional system, lest their careers be ended.

\section{Conclusion}

This chapter described the implementation of the domestic violence policy in specialized domestic violence courts in Espírito Santo, Brazil. The specialized courts were established after 2006, when the federal government enacted Maria da Penha Law. The law prescribed the creation of specialized courts to deal exclusively with cases of domestic violence. Based on the literature on judicial politics, this study identified legal and non-legal factors that influenced the decision-making of prosecutors and judges in these specialized courts. Importantly, the findings in this study also draw from interviews of other criminal justice professionals. The interviews sought to identify these professionals' opinions about the law, institutional constraints, feelings about working with domestic violence cases, and perceptions about their role in the policy implementation and their interactions with other institutions. Factors were identified through the information gleaned from the type and number of questions that prosecutors, public defenders, and judges asked victims and offenders during court hearings. The assessment of perceptions, opinions, and feelings was based on interviews.

Regarding the factors influencing the decision-making of prosecutors and judges, this study organized them according to the characteristics of the offense, the victim, the accused, the prosecutor, and the organization or agency. Both prosecutors and judges took into consideration 
how severe the injury was, whether the case had witnesses, and the motive for the offense. Prosecutors also asked questions about the weapon that may have been used by the accused. In regards to characteristics of the victim, prosecutors were concerned about the victim's relationship with the accused. They asked if the victims had children with the accused, if they had been victim of prior abuse, their level of fear of offenders and level of cooperation (in other words, to the extent to which a victim seemed willing to answer questions), whether they provided information about the accused, and whether they wanted full continuation of the investigation and the accused arrested.

Judges were also concerned about the relationship statuses of victims, the existence of children, and victims' level of fear, but also added questions about the victim's behavior in court and at home, including whether she was a good mother and if she had addictions or history of drug or substance abuse. Prosecutors and judges had similar concerns regarding characteristics of the accused. In the majority of court hearings, they asked questions about defendant's criminal history, use of drugs or alcohol, employment statuses, and behavior at home, in other words, if he is a good father or good husband who just happened to lose control when he was drunk or drugged and battered his wife.

Overall, the nature of these questions supports the argument made in this chapter that prosecutors, judges, and criminal justice professionals, including police officers, are part of a community that shares similar attitudes and perceptions about victims, batterers, and regarding the cases of domestic violence in general. This argument debunks the legal metaphor by showing that decision-making of these actors is influenced by several factors other than the law, many of which are a result of actors' daily interactions and the sharing of perceptions regarding domestic violence work. 
While they belonged in different institutions, police officers, prosecutors, judges, and other criminal justice professionals interviewed in this study seemed to have similar perceptions about the policy, institutional constraints, their feelings, and perceptions about their roles in domestic policy work. The majority of the respondents believed the law was either inefficient or unjust. Those who considered the law inefficient did so because they viewed domestic violence as a social problem where the law was only a part of the solution. This chapter also demonstrated that the implementation of the domestic violence law in Brazil is faced with a number of constraints, including limited financial and infrastructural resources, lack of multidisciplinary staff in most places, lack of specialized courts in rural areas, inadequate staff, and an explosion of case workload. The court actors interviewed expressed great frustration with their work, describing it as overwhelming, unrewarding, and emotionally draining. Yet, the majority of them believed that they were providing a therapeutic or social service, in their role in policy implementation. The only, yet minor, difference in opinion was between criminal justice professionals and police officers in regards to their perceptions about interactions with other institutions. While police officers shared feelings about a sense of isolation and disconnect with the prosecutor's office and the courts, criminal justice professionals reported having a good relationship with the police. 


\section{Chapter 5: Conclusions}

This study investigated the role of police and courts in the implementation of the 2006 domestic violence law, known as Maria da Penha Law, in Brazil. To this end, the study explored the kinds of information police officers, prosecutors, public attorneys and judges working with domestic violence cases in the state of Espírito Santo, seek from victims and defendants in police stations and domestic violence courts. In particular, the study aimed to identify the information these legal actors deem relevant to seek for during interrogations and in court hearings. Relatedly, the research sought to understand how these and other criminal justice professionals perceive the domestic violence policy created by Maria da Penha Legislation. The study considered how the perceptions of the policy by the legal professionals were shaped by their interactions among themselves and between themselves and domestic violence victims and offenders. Accordingly, the research explored the opinions of these professionals regarding their understanding of the domestic violence law, the extent to which they applied it in their decisionmaking, and their perceptions of their own roles and responsibilities in implementing the law. The study also explored how these professionals perceive the institutional constraints they faced in implementing the law, as well as their perceptions about domestic violence victims and defendants. The study particularly sought to answer the following two related questions: a) Are domestic violence legal professionals in Brazil influenced by extra-legal factors in their decisionmaking? b) What are the specific factors influencing the decision-making of police officers, prosecutors, public attorneys, and judges who work with domestic violence cases in Espírito Santo, Brazil?

Historically, police force, courts, and the general society have been quiet about thousands of cases where individuals, the majority of them women, have been injured and killed by 
partners or family members. Worldwide, this pattern is often interrupted when governments become proactive in acknowledging domestic violence as a crime and setting new standards on how police and courts should respond. Countries have developed and implemented domestic violence policies using either a legalistic or a human rights approach. While the legalistic perspective focuses on matters of law enforcement, the human rights perspective aims to provide broader solutions that address victims' economic and social status, in addition to the legal adjustments.

The domestic violence policy in Brazil has been mainly informed by the human rights approach. Nevertheless, the initial policy was to a greater extent shaped by the legalistic perspective. Indeed, one of the first measures against domestic violence was the establishment of women's police stations in 1985. The most transformative law, enacted in 2006, known as Maria da Penha Law, which created courts specialized in domestic violence crimes was influenced by the human rights perspective. These policy responses were largely possible due to influences from both the Brazilian feminist movement and international activist groups. While the creation of the police stations was a result of pressure from local forces, including the feminist movement, the enactment of Maria da Penha Law was mainly an outcome of political mobilization at the international arena. A network of interest groups and advocates reached out to the Inter-American Convention to Prevent, Sanction, and Eradicate Violence Against Women and brought international attention to how cases of domestic violence were being treated by police in Brazil. The Convention pressured the Brazilian government to adopt immediate measures to address cases of domestic violence.

Ultimately, the government established special police stations and courts to deal with women violence cases. However, police officers, prosecutors, judges, and other criminal justice 
professionals faced, and, as this study established, continue to face many institutional constraints in implementing the policy. One of the most critical constraints was, and still remains, the lack of special training. The lack of understanding of the complexity of domestic violence, and the absence of standardized procedures on how cases must be reported and registered left officials poorly equipped. Consequently, most officials used their own judgment, values, and intuitions when dealing with domestic violence cases. This domestic violence policy scenario begs a number of questions that related to the broad questions addressed in this study: how reasonable is it to expect police officers, judges, prosecutors and other legal professionals to effectively sanction a behavior that has been historically and culturally entrenched in, yet ignored by, the Brazilian society at large? Should these stakeholders be expected to exclusively follow the law? What other factors, besides legal considerations, that could influence the ways in these stakeholders interact with victims and batterers? Bearing these questions in mind, to what extent are the stakeholders helping or hindering the implementation of domestic violence policy in Brazil?

In general, research on policing and judicial decision-making show that legal professionals are influenced by an array of factors. In cases of domestic violence, in particular, police officers, prosecutors, public attorneys, and judges often take into consideration the degree of the offense, as well as the life-histories victims and batterers and level of cooperation with cases. Based on the court community literature, this study established or confirmed that Brazilian criminal justice professionals have also been influenced by these characteristics. Furthermore, findings in this study support the court community literature argument that individuals at police or courts form a community that exchanges values and perspectives through their daily interactions. Those values and perspectives shape the outcomes of domestic violence cases. 
Accordingly, this dissertation was organized in a manner that highlights the historic development of the policy in the United States and in Brazil, sheds lights on the influence of international bodies in shaping the creation of the domestic violence policy in Brazil, and finally, explores its implementation in the police and courts of the state of Espírito Santo. Chapter one showed the first developments of domestic violence policy in the United States and in other countries. The chapter specifically demonstrated that domestic violence in the US and several other countries was framed as a political and legal issue because advocates and interest groups mobilized to introduce it in political agendas of countries. As a result, the concept of domestic violence as an issue that required government intervention emerged. This conception of domestic violence drastically changed how police and courts functioned, although there was a great deal of reluctance from these institutions during the initial implementation of measures developed to address the violence. For example, police officers in the US continued refusing to respond to domestic violence calls, ignoring statutes demanding their prompt attention. Prosecutors often blamed victims for lack of cooperation, and judges sentenced less severe punishments. This reluctance was also not unique to the US, as it was observed in other countries, especially in developing countries, where women still face challenges of political, social, and economic nature.

Chapter two presented the development of the domestic violence policy in Brazil. Like in the United States, the policy in Brazil was a result of pressure from activists, especially the women's rights movement. The movement mobilized locally and internationally to advance the creation of women's police stations and the enactment of the Maria da Penha law. There was, however, little enthusiasm from police and court officials. Lack of funding, inadequately defined institutional structure, and mistrust of the government contributed to the reluctance by police and 
courts to act. In fact, many judges only applied the domestic violence law after the Brazilian Supreme Court confirmed its constitutionality at the request of the President. Notwithstanding the Supreme Court clarification, the lower level bureaucrats, police officers, prosecutors, judges, and criminal justice professionals were still left to their devices in the implementation of the domestic violence policy at the local level.

Chapters three and four presented and discussed this study's empirical findings based on the author's observations and interviews conducted at police stations and special domestic violence courts in Espírito Santo. Accordingly, the study found that while the police force and courts differ institutionally, respondents from both institutions shared similar views about their role, the law, and their work with domestic violence. Overall, they saw their role as that of “social workers," given the psychological, social, and financial dimensions of domestic violence. Attempts to play the role of a social worker seems to have led the majority respondents to have negative impressions about the law and to believe the law allowed certain women to "play the victims" and "use the system to get the men out of the house."

Unsurprisingly, the majority of respondents considered their work frustrating, especially since a high number of victims often went back to the same, or began another, abusive relationship. Perceptions about the cases of domestic violence, victims, and batterers were equally similar and equally negative. Based on this study's observations of the interactions between police and court officials with victims and batterers, and the information shared during interrogations and court hearings, it is safe to argue that officials are unaware of the complexities of domestic violence cases. In many cases, officials suggested that victims could easily disengage from abusive relationships. As such, officials seemed to unconsciously search for the ideal victim: the stereotypical view of a helpless, sad, and fearful woman, who is a good mother 
and wife, who doesn't drink or smoke, and needs to be rescued from an abusive relationship. Furthermore, there was also the stereotype of the batterer: a man who is a good father, good husband, employed, who lost control during one incident because he was under the influence of drugs or alcohol. It is unsurprising, therefore, that during interrogation and court hearings, officials often asked the victim if she used to drink, if she had children from other relationships, if she was a good mother, why she remained in the relationship if there was prior abuse, if the batterer is a good father, good husband, if he is employed, how long they have been together, if they have properties together, and etc.

In sum, these two chapters appropriately answered the research questions, establishing that a) police officers, prosecutors, and judges were influenced by several factors other than the law; and b) they share similar attitudes toward victims, batterers, and cases of domestic violence, these findings are in line with court community literature. The following tables provide a summarized list of all the variables that influenced the decision-making of these officials, based on the study conducted in Brazil, and as framed by domestic violence studies in the United States. 


\begin{tabular}{|cc|c|c|}
\hline \multicolumn{3}{|c|}{ FACTORS INFLUENCING DECISION-MAKING OF } \\
BRAZILIAN OFFICIALS
\end{tabular}

Table 5: Comparison of factors influencing decision-making of Brazilian criminal justice professionals (police officers, prosecutors, and judges).

\begin{tabular}{|c|c|c|c|}
\hline \multicolumn{4}{|c|}{$\begin{array}{l}\text { FACTORS INFLUENCING DECISION-MAKING OF } \\
\text { U.S. OFFICIALS }\end{array}$} \\
\hline Characteristics & Police Officers & Prosecutors & Judges \\
\hline Offense & $\begin{array}{c}\text { Injury } \\
\text { Violation of } \\
\text { Restraining } \\
\text { Order } \\
\text { Weapon }\end{array}$ & Injury & Injury \\
\hline Victim & $\begin{array}{c}\text { Cooperation } \\
\text { Substance abuse } \\
\text { Historyof abuse } \\
\text { Fear }\end{array}$ & $\begin{array}{l}\text { Cooperation } \\
\text { Substance abuse } \\
\text { Behavior in } \\
\text { court } \\
\text { Promiscuity }\end{array}$ & Cooperation \\
\hline Batterer & $\begin{array}{c}\text { Substance abuse } \\
\text { Criminal history } \\
\text { Demeanor }\end{array}$ & $\begin{array}{l}\text { Substance abuse } \\
\text { Criminal history } \\
\text { Missed hearing } \\
\text { Weapon }\end{array}$ & $\begin{array}{c}\text { Substance } \\
\text { abuse } \\
\text { Criminal } \\
\text { history } \\
\\
\\
\text { Employment } \\
\text { Children }\end{array}$ \\
\hline Official & $\begin{array}{l}\text { Attitudes } \\
\text { Training } \\
\text { Place } \\
\text { Gender } \\
\text { Experience }\end{array}$ & Attitudes & $\begin{array}{l}\text { Attitudes } \\
\text { Training }\end{array}$ \\
\hline
\end{tabular}

Table 6: Comparison of factors influencing decision-making of U.S. criminal justice professionals (police officers, prosecutors, and judges). 
These results echo findings from landmark studies on organizational theory (Blumberg, 1967; Feeley, 1973; Eisenstein \& Jacob, 1977; Heumann, 1978; Nardulli, 1978; Jacob, 1983) and court community culture (Feeley, 1979, 1983; Eisenstein, Flemming, \& Nardulli, 1988; Jacob, 1997; Flemming, 1998). These studies and the findings of this research strongly support the view that internal and external factors, as well as the existence of a community culture developed through the sharing of values and attitudes, influence police and court officials when dealing with domestic violence. Moreover, and in line with this view, this dissertation especially adds to Baum's work on judicial specialization (2011). As this study has demonstrated, in Brazil, a multiplicity of influences, which appear to be an effect of judicial specialization particularly in the context of specialized domestic violence courts, are evident.

It is evident that the current Domestic Violence Policy in Espírito Santo, and I suspect in other parts of Brazil, is not being implemented as envisioned by legislators and activists. The law prescribes the hiring of trained officials working in ample offices, fully equipped, and supported by multidisciplinary staff including psychologists, social workers, and lawyers, among other professionals. It also prescribed expedited proceedings where victims would be provided with access to social, psychological, and financial assistance. Victims should also be granted legal protection from unemployment, in case they missed work because of fear of victimization.

In general, this study's contributions to the understanding of domestic violence policy are threefold. First, domestic violence is an issue that is somewhat recent in the governmental agenda, and that is yet to be to be properly framed as an issue of public interest in many other countries. As mentioned earlier, there were high expectations that the Brazilian model of domestic violence police units, the women's police stations, and the specialized domestic violence courts could be replicated to other countries. Several other countries started 
implementing the same model, despite the limited number of studies assessing its efficacy. Regardless of the outcomes of the policy, this research found that the policy enhanced political opportunities for a small group of politicians and quieted the claims of the Brazilian feminist movement for a little while.

Second, in comparing how domestic policies developed in the United States and in Brazil, this study demonstrated that the Brazilian experience is not unique. In fact, in both countries, culture and law have shaped the norms and behaviors of domestic violence policy stakeholders. Related to this, it was revealed how officials expressed and reinforced their cultural orientation against the criminalization of domestic violence, while the law demanded it to be treated as any other crime. Third, this study shed light on how these negotiations occur on a daily basis both in the police stations and courts, when officials had to assess the relationship statuses of victims in order to ensure that they were doing the right thing. Indeed, a major contribution of this study in this context is the demonstration of the importance of training and educating officials, providing them with tools not only to better understand the complexities of domestic violence, but also to avoid the high levels of frustration and emotional problems reported by many respondents. Thus, those interested in domestic violence policy should pay attention not only to the political interests at stake, but to the possible cultural conflicts, which are likely to be negotiated at police stations and courts, ultimately hindering policy implementation. In sum, this study’s findings, as well as its limitations offer useful lessons to stakeholders of domestic violence policy, including policy makers and scholars, in Brazil and elsewhere in the world.

The findings of this study suggest that policy makers in Espírito Santo and in Brazil more generally need to do the following to improve the implementation of the domestic violence policy: a) more specialized courts need to be created, especially in the rural areas. Related to this, 
attention should also be paid to the physical infrastructure of court facilities. In this context, the court houses should be spacious and have separate compartments to provide victims with more sense of privacy; b) there should be a better integration between the police, courts, and the office of prosecutor. As it was found in this study, the three institutions operate like three islands, slowing the progression of domestic violence cases; c) these institutions should closely work with extra-legal service providers, such as social workers, mental health professionals and social welfare support groups; d) given the complexity of domestic violence, all legal professionals working with domestic violence courts, including judges, police officers, and prosecutors should be provided with special training. The training should equip the professional with skills that would allow them to treat each domestic case with care and not to use cultural stereotypes when interrogating victims and defendants. Moreover, special training could improve their experiences at work and allow them to appreciate the value of working with domestic violence cases. As the study showed, there were discrepancies between the role assigned by the law and what legal profesionals considered it to be, as reflected in their daily practices. Moreover, these discrepancies were liked individual's feelings and perceptions about the characteristics of victims, batterers, and individuals' biases, issues that could be addressed in special training programs; and e) mores specialized police stations should be established in rural areas. Police officers there, regardless of gender, should have domestic violence special training. In the absence of forense police in rural areas, police stations there should develop partnerships with hospitals whereby doctors could help in identifying victims of domestic violence and documenting their injuries. This partnership could help victims who suffer in silence, given the conservative nature of rural populations. 
This study has a few limitations. One of the main limitations was the length of case proceedings and lack of access to the judicial cases. This study was conducted based on interviews and observations conducted at women's police stations and domestic violence specialized courts in Espírito Santo, Brazil. Initially, the aim of this study was to conduct interviews and gather comprehensive information from the case files regarding demographic characteristics of victims and defendants. Such information would have included attributes like age, race, employment, and education, allowing for better conclusions to be made regarding how these characteristics affected the decision-making of police officers, prosecutors, and judges. Another initial goal of this study was to track the progression of each case considered, throughout its entire cycle as it moved from one stage to the next, till the sentencing phase. However, it was not expected that the majority of the cases could take as many as three years to be concluded. As such, given the extended procedural length and the lack of access to comprehensive information on the cases, the focus of the study was reoriented to only include the observations of the dynamics in the police stations and courts. The new focus allowed for the discovery of very useful qualitative data that would have been missed otherwise. For example, the observation of court hearings brought to light the values and attitudes tacitly exchanged between police officers, prosecutors, and judges with victims and defendants.

However, more work needs to be done to gain a complete picture of all factors that influence decision-making of all stakeholders of domestic violence cases. There is need, for example, to seek a better understanding of cultural influences and the impact of training on regions of Brazil that have high cases of honor killing. Studies could also identify best practices regarding partnerships between government and the third sector, in particular, interest groups that target advancement of women's rights. It is also important to investigate if there are 
differences in the sentencing of domestic violence cases based on victim's race, age, employment, and education level. An exploration of these issues, coupled with quantitative analysis of cases can further better our understanding of domestic violence policy worldwide.

In summations, in order to understand the role of police and courts in the implementation of domestic violence policy, it was important to identify what individuals from these spheres feel and think about their work. This study showed that there might be discrepancies between the role assigned by the law, perceived by those individuals, and what was indeed observed in daily practices. This study was able to show that part of these discrepancies was due to feelings and perceptions about the characteristics of victims, batterers, and individuals' biases. While a standard view of policy implementation favors more laws and more punishment, this work challenged this assumption by showing that any policy implementation must also take into consideration the organizational culture existent in institutions. Most importantly, this study acknowledged that this culture is reinforced through not only the existence of networks, but also the power of relationships within and between the police and the courts. 


\section{References}

42 U.S.C. $§ 1983$.

Albonetti, C. A. (1987). Prosecutorial discretion: The effects of uncertainty. Wiley Subscription Services, Inc.

Almeida, S. S. (1998). Femicídio: algemas (in) visíveis do público-privado. Revinter: Rio de Janeiro, RJ.

Alvarez, S. E. (1990). Engendering Democracy in Brazil: Women's Movements in Transition Politics. Princeton: Princeton University Press.

Alvarez, S. E. (2000). En qué estado está el feminismo? Reflexiones teóricas y perspectivas comparativas. Estudios Latinoamericanos, 12(13), 47-66.

Amaral, C. C. G. (2001). Dores Visíveis. Violência em delegacias da mulher no Nordeste. Fortaleza: REDOR/NEGIF.

Ames, L., \& Dunham, K. (2002). Asymptotic justice -probation as a criminal justice response to intimate partner violence. Violence Against Women, 8(1), 6-34.

Ampofo, A. (2008). Collective activism: The domestic violence bill becoming law in Ghana. African and Asian Studies, 7(4), 395-395.

Andrews, P. (1997). Violence against women in Australia: Possibilities for redress within the international human rights framework. Albany Law Review, 60, 917-1949.

Aquino, S. (2008). Pathways of women's empowerment through legal strategies: the case of Maria da Penha Law. Brazil

Ardaillon D. \& Debert, G. (1987). Quando a vítima é mulher: Análise de julgamentos de crimes de estupro, espancamentos e homicidios. Conselho Nacional dos Direitos da Mulher. CNDM, Ministério da Justiça, Brasília. 
Ardaillon, D. (1989). Estado e mulher: conselhos dos direitos da mulher e delegacias de defesa da mulher. São Paulo: Fundação Carlos Chagas.

Ardayfio-Schandorf, E. (2005). Violence against women: The Ghanaian case. Violence against women: a statistical overview, challenges and gaps in data collection and methodology and approaches for overcoming them. Geneva, Switzerland: UN Division for the Advancement of Women.

Austin, T., \& Buzawa, E. S. (1993). Determining police response to domestic violence victims: The role of victim preference. American Behavioral Scientist, 36(5), 610-623.

Baar, E., \& Baar, C. (1977). Judges as middlemen? The Justice System Journal, 2(3), 210-225. Bachman, R., \& Coker, A. L. (1995). Police involvement in domestic violence: The interactive effects of victim injury, offender's history of violence, and race. Violence and Victims, 10, 91-106.

Balanço: Pacto Nacional pelo Enfrentamento a Violencia contra as Mulheres, 2007-2010 (2010). Presidencia da Republica: Secretaria de Politicas para Mulheres.

Balos, B., \& Trotsky, K. (19988). Enforcement of the domestic abuse act in Minnesota: A preliminary study. Law \& Inequality, 6, 83-125.

Bard, M. (1967). Training police as specialists in family crisis intervention: A community psychology action program. Community Mental Health Journal, 3, 315-317.

Bard, M., \& Zacker, J. (1971). The Prevention of Family Violence: Dilemmas of Community Interaction. Journal of Marriage and the Family, 33, 677-682.

Bard, M., \& Connolly, H. (1978). The police and family violence: Practice and policy. Battered women: Issues of public policy. 309-326. Washington, D.C.: U.S. Civil Rights Commission. 
Barnes, P. G. (1998). Domestic violence: From a private matter to a federal offense. New York: Garland Pub.

Barsted, L. L. (1994). Em Busca do Tempo Perdido: Mulher e Politicas Públicas no Brasil 19831993. Revista Estudos Feministas, 38-54.

Barsted L. L., \& Hermann J. (1999). Instrumentos internacionais de proteção aos direitos humanos: os direitos das mulheres são direitos humanos. Rio de Janeiro: CEPIA; 1999.

Barsted, L. L. (2006). O avanço legislativo no enfrentamento da violência contra as mulheres. In Leocádio, E and Libardoni, M. O desafio de construir redes de atenção às mulheres em situação de violencia, Brasília: AGENDE Ações em Gênero Cidadania e Desenvolvimento, 65-89.

Barsted, L. L. (2007). A resposta legislativa à violência contra as mulheres. In: Almeida, S. Violência de Gênero e Políticas Públicas. Rio de Janeiro: Editora UFRJ, Série Didáticos.

Baum, L. (2011). Specializing the courts. Chicago: The University of Chicago Press.

Belknap, J., \& McCall, K. D. (1994). Woman battering and police referals. Journal of Criminal Justice, 22(3), 223-236.

Belknap, J., Hartman, J. L., \& Lippen, V. L. (2010). Misdemeanor domestic violence cases in the courts: A detailed description of the cases. Female victims of crime: Reality reconsidered, 259-78. Columbus, OH: Prentice Hall.

Berk, A. F., \& Loseke, D. R. (1981). "Handling” family violence: Situational determinants of police arrest in domestic violence. Law \& Society Review, 15 (2), 317-346.

Berk, R. A., Campbell, A., Klap, R., \& Western, B. (1992). The deterrent effects of arrest in incidents of domestic violence: A Bayesian analysis of four field experiments. American Sociological Review, 57, 698-708. 
Berman, G., \& Feinblatt, J. (2001). Problem-Solving courts: A brief primer. Law \& Policy, 23(2), 125-140. doi:10.1111/1467-9930.00107.

Besse, S. K. (1989). Crimes of passion: The campaign against wife killing in Brazil, 1910-1940. Journal of Social History, 22(4), 653-666. doi:10.1353/jsh/22.4.653

Binder, A., \& Meeker, J. W. (1988). Experiments as reforms. Journal of Criminal Justice, 16, $347-358$.

Blackwell, B. S., \& Vaughn, M. S. (2003). Police civil liability for inappropriate response to domestic assault victims. Journal of Criminal Justice, 31, 129-146.

Blay, E. A. (2003). Violência contra a mulher e políticas públicas. Estudos avançados, 17(49), 87-98.

Blumberg, A. S. (1967). Criminal justice. Chicago: Quadrangle Books.

Bourg, S., \& Stock, H. V. (1994). A review of domestic violence arrest statistics in a police department using pro-arrest policy: Are proarrest policies enough? Journal of Family Violence, 9, 177-189.

Bowker, L. H. (1982). Police services to battered women: Bad or not so bad. Criminal Justice and Behavior, 9, 476-494.

Brandão, E. R. (1998). Violência conjugal e o recurso feminino à polícia. In Bruschini C. \& Holandam H, B. Horizontes plurais: novos estudos de gênero no Brasil. 34, 51-84. São Paulo: Editora.

Brasil, 2006. BRASIL. Lei nº. 11.340, de 7 de agosto de 2006. Lei Maria da Penha: Coíbe a violência doméstica e familiar contra a mulher. Brasília: Secretaria Especial de Políticas para as Mulheres, 2006, 31.31 p. 
"Brazil femicide law signed by President Rousseff." (2015). BBC News. Retrieved from http://www.bbc.com/news/world-latin-america-31810284.

Breci, M.G. (1989). The effect of training on police attitudes toward family violence: Where does mandatory arrest fit in? Journal of Criminal Justice, 12, 35-49.

Bruno v. Codd, 90 Misc. 2d 1047, 396 N.Y.S.2d 974 (Sup. Ct. 1977)

Bunch, C. (1990). Women's rights as human rights: Toward a re-vision of human rights. Human Rights Quarterly, 12(4), 486-498.

Burkemper, J. B. \& Balsam, N. (2007). Examining the use of restorative justice practices in domestic violence cases. Saint Louis University Public Law Review, 27, 121-427.

Busch. (1994). An analysis of New Zealand judges' attitudes towards domestic violence. Women, Male Violence, and the Law. Sydney: Institute of Criminology.

Buzawa, E. S., \& Buzawa, C. G. (Eds.). (1990). Domestic violence: The criminal justice response. Westwood, CT: Auburn House.

Buzawa, E.S. \& Buzawa, C.G. (1993a). Opening the doors: The changing police response to domestic violence. In Dunham, R. G. \& Alpert, G.P. (eds.) Critical issues in policing: Contemporary readings, 551-567. Prospect Heights, Il: Waveland Press.

Buzawa, E. S., \& Austin, T. (1993b). Determining police response to domestic violence victims: The role of victim preference. American Behavioral Scientist, 36, 610-623.

Buzawa, E.S. and C.G. Buzawa. (1996). Domestic Violence: The Criminal Justice Response. Newbury Park, CA: Sage.

Buzawa, E. S., \& Buzawa, C. G. (2003). Domestic violence: The criminal justice response (3rd ed.). Thousand Oaks, CA: Sage. 
Cahn, N.R. \& Lerman, L. G. (1991). Prosecuting Woman Abuse. Woman Battering: Policy Responses. 95-112. Cincinnati, $\mathrm{OH}$ : Anderson.

Cahn, N.R. (1992). Innovative Approaches to the Prosecution of Domestic Violence Crimes: An Overview. Domestic Violence: The Changing Criminal Justice Response. 161-80. Westport, CT: Auburn House.

Camacho, C. M. \& Alarid, L. F. (2008). The significance of the victim advocate for domestic violence victims in municipal court. Violence and Victims, 23(3), 288.

Campos, C. H. (2003). Juizados Especiais Criminais e seu déficit teórico (The Theoretical Deficit of Special Criminal Courts). Revista Estudos Feministas (Feminist Studies Journal), 11(1), 155-170. Santa Catarina: UFSC.

Carns, T. W., Hotchkin, M. G., \& Andrews, E. M. (2002). Therapeutic Justice in Alaska's Courts. Alaska Law Review, (19), 1: 1-56.

Cassidy, M. A., \& Trafimow, D. (2002). The influence of patriachal ideology on outcomes of legal decisions involving woman-battering cases: An analysis of five historical eras. Social Science Journal, 39(2), 235-245.

Centro Nicaragüense de Derechos Humanos Centro nicaraguense de derechos humanos CENIDH. (1995). Derecho que no se defiende; derecho que se pierde. Managua: Imprimatur.

CFEMEA - Centro feminista de estudos e assessoria. (2011). 5 anos da Lei Maria da Penha: Comemorando nossas conquistas exigindo direitos para todas nós. Brasília-DF, Brasil.

Chalk, R., \& King, P. A. (1998). Violence in the family: Assessing prevention and treatment programs. Washington, D.C.: National Academy Press. 
Chase, D., \& Hora, P. F. (2000). The implications of therapeutic jurisprudence for judicial satisfaction. Court Review, 37 (1), 12-20.

Clement, K., Tatum, K., Kruse, M., \& Kunselman, J. (2009). Exploring agency policing models and response to domestic violence. Policing - An International Journal of Police Strategies \& Management, 32(1), 92-107. doi:10.1108/13639510910937139

Clifford, D., Hertz, F., Doskow, E., \& Curry, H. (2007). A legal guide for lesbian and gay couples. Berkeley, CA: Nolo.

CNJ avalia decisao que tachou lei Maria da Penha de monstrengo. (2007). Consultor Juridico. Retrieved from http://www.conjur.com.br/2007-out23/cnj_avalia_decisao_tachou_lei_monstrengo_tinhoso.

Cochran, A. B., \& Cavazotte, F. (2009). Comparing Brazilian and US Harassment Policies: Implications for Reporting. The International Studies Association Meeting.

Conselho Nacional dos Direitos da Mulher. (2001). Pesquisa nacional sobre as condições de funcionamento das delegacias especializadas no atendimento às mulheres: Relatório final. Brasília: Conselho Nacional dos Direitos da Mulher.

Cortez, M. B., \& de Souza, L. (2008). Subordinated women: Feminine empowerment and its repercussions on marital violence occurrences/Mulheres subordinadas: O empoderamento feminino e suas repercussoes nas ocorrencias de violencia conjugal. Psicologia: Teoria e Pesquisa, 24(2), 171.

Crocker, D. (2005). Regulating intimacy: Judicial discourse in cases of wife assault (1970 to 2000). Violence Against Women, 11(2), 197-226.

Crowley, J. E., Sigler, R. T., \& Johnson, I. M. (1990). Variations across agency types to perceptions of seriousness of family abuse. Journal of Criminal Justice, 18: 519-531. 
Da Fonseca, R. M. G. S., Egry, E. Y., Guedes, R. N., Gutierres, A. R., \& Tezzei, F. P. N. (2011). Violence against women: A study of the reports to police in the city of itapevi, São Paulo, Brazil. Midwifery, 27(4), 469-473. doi:10.1016/j.midw.2010.03.004

Dalton, C., \& Schneider, E. M. (2008). Domestic violence and the law: Theory and practice. New York: Foundation Press.

Daniels, C. R. (1997). Feminist Negotiate the State: The Politics of Domestic Violence. Lanham: Univ. Press of America. Pp. 5-10.

Dauer, S. (2001). Indivisible or invisible: Women's human rights in the public and private sphere, 65-82.

Davis, R. C., \& Smith, B. E. (1981). Crimes between acquaintances: The response of criminal courts. Victimology, 6:175-87.

Dawson, M., \& Dinovitzer, R. (2001). Victim cooperation and the prosecution of domestic violence in a specialized court. Justice Quarterly, 18(3), 593-622.

Debert, G. G. (2006). As delegacias de defesa da mulher: judicialização das relações sociais ou politização da justiça? In Corrêa M., \& de Souza E. R., (orgs.), Vida em família: uma perspectiva comparativa sobre “crimes de honra”. Campinas, SP: Pagu-Núcleo de Estudos de Gênero/Universidade Estadual de Campinas, 16-38.

Declaration on the Elimination of Violence Against Women. (1993). A/RES/48/104 Declaration on the Elimination of Violence Against Women - UN Documents: Gathering a body of global agreements. Retrieved from http://www.un-documents.net/a48r104.htm.

Decree-Law 2.848/1940: Penal code of Brazil. Retrieved from http://www.planalto.gov.br/ccivil_03/Decreto-Lei/Del2848.htm. 
Defensoria Pública do Estado do Pará. (2008). Direitos da Mulher Vitima de Violencia Domestica e Familiar. Núcleo de Atendimento Especializado da Mulher Vítima de Violência Doméstica e Familiar (NAEM).

DeLeon-Granados, W., Wells, W., \& Binsbacher, R. (2006). Arresting developments: Trends in female arrests for domestic violence and proposed explanations. Violence Against Women, 12(4), 355.

Dempsey, M. M. (2007). Toward a feminist state: What does 'effective' prosecution of domestic violence mean? The Modern Law Review, . (70) 6, 908-935.

Diniz, C. S. G. (2006). Violência contra a mulher: estratégias e respostas do movimento feminista no Brasil (1980-2005). Vinte e cinco anos de respostas brasileiras em violência contra a mulher, (1), 15-44. São Paulo: Ed. Coletivo Feminista.

Dobash, R. E., \& Dobash, R. P. (1979). Violence against wives: A case against the patriarch. New York: The Free Press.

Dobash, R. E. (2003). Domestic violence: Arrest, prosecution, and reducing violence. Criminology \& Public Policy, 2(2), 313-318. doi:10.1111/j.1745-9133.2003.tb00127.x

Du Mont, J., Miller, K., \& Myhr, T. L. (2003). The role of "real rape" and "real victim" stereotypes in the police reporting practices of sexually assaulted women. Violence Against Women, 9(4), 466-486. doi:10.1177/1077801202250960

Dunford, F. W. (1990). System initiated warrants for suspects of misdemeanor domestic assault: A pilot study. Justice Quarterly, 7, 631-653.

Dunford, F. W., Huizinga, D., \& Elliott, D. S. (1990). The role of arrest in domestic assault: The Omaha Police Experiment. Criminology, 28, 183-206. 
Dunn, J. L. (2001). Innocence lost: Accomplishing victimization in intimate stalking cases. Symbolic Interaction, 24(3), 285-313. doi:10.1525/si.2001.24.3.285

Dutton, D. G. (1995). The domestic assault of women (2nd ed.). Boston: Allynn-Bacon.

Eisenstein, J., \& Jacob, H. (1977). Felony Justice, Boston: Little, Brown and Co.

Eisenstein, J., Flemming, R. B., \& Nardulli, P. F. (1988). The contours of justice: Communities and their courts. Boston: Little, Brown.

Eitle, D. (2005). The influence of mandatory arrest policies, police organizational characteristics, and situational variables on the probability of arrest in domestic violence cases. Crime \& Delinquency, 51, 573-597.

Eley, S. (2005). Changing practices: The specialised domestic violence court process. The Howard Journal of Criminal Justice, 44(2), 113-124. doi:10.1111/j.14682311.2005.00361.x

Elliott, D. S. (1989). Criminal Justice Procedures in Family Violence Crimes. Family Violence, Crime and Justice, 11, 427-80. Chicago, IL: University of Chicago Press.

Ellis, D., Choi, A., \& Blaus, C. (1993). Injuries to police officers attending domestic disturbances: An empirical study. Canadian Journal of Criminology, 35 (2), 149-168.

Ellis, J.W. (1984). Prosecutorial Discretion to Charge in Cases of Spousal Assault: A Dialogue. Journal of Criminal Law and Criminology, 75:56-102.

Epstein, D. (1999). Effective intervention in domestic violence cases: Rethinking the roles of prosecutors, judges, and the court system. Yale Journal of Law and Feminism, 11, 3-50. Epstein, D. (2002). Procedural justice: Tempering the state's response to domestic violence. William and Mary Law Review, 43(5), 1843. 
Erez, E., \& Belknap, J. (1998). In Their Own Words: Battered Women's Assessments of the Criminal Processing System's Responses. Violence and Victims, 13:251-68.

Erwin, P. E. (2006). Exporting U.S. domestic violence reforms: An analysis of human rights frameworks and U.S. "best practices." Feminist Criminology, 1(3), 188-206. doi:10.1177/1557085106290271

Fagan, J., \& Browne, A. (1994). Violence between spouses and intimates: Physical aggression between women and men in intimate relationships. In Reiss, A. J., \& Roth J. A. (Eds.), Understanding and Preventing Violence, 3, 115-292. Social Influences (pp.115-292). Washington, DC: National Academy Press.

Fagan, J. (1996). The criminalization of domestic violence: Promises and limits. Washington D.C.: National Institute of Justice.

Feder, L. (1999). Women and Domestic Violence: An Interdisciplinary Approach. New York: Haworth Press. P. 22.

Feeley, M. M. (1973). Two models of the criminal justice system: An organizational perspective. Law \& Society Review, 7(3), 407-425.

Feeley, M. M. (1979). The process is the punishment: Handling cases in a lower criminal court. New York: Russell Sage Foundation.

Feeley, M. M. (1983). Court reform on trial: Why simple solutions fail. New York: Basic Books. Ferraro, K. J. (1989). Policing Woman Battering. Social Problems, 36, 61-74.

Few, A. L. (2005). The voices of black and white rural battered women in domestic violence shelters. Family Relations, 54(4), 488-500. doi:10.1111/j.1741-3729.2005.00335 
Finn, M. A., Blackwell, B. S., Stalans, L. J., Studdard, S., \& Dugan, L. (2004). Dual arrest decision in domestic violence cases: The influence of departmental policies. Crime and Delinquency, 50, 565-589.

Finn, M. A., \& Bettis, P. (2006). Punitive action or gentle persuasion: Exploring police officers' justifications for using dual arrest in domestic violence cases. Violence Against Women, $12,268-287$.

Flemming, R. B., Nardulli, P. F., \& Eisenstein, J. (1992). The craft of justice: Politics and work in criminal court communities. Philadelphia: University of Pennsylvania Press.

Flemming, R. B. (1998). Contested terrains and regime politics: Thinking about America's trial courts and institutional change. Law and Social Inquiry, 23, 941-1045.

Flores, S. R. (2000). Informe de la encuesta a mujeres policías (Policía Nacional Civil) (Report on the Survey of Women Police (National Civil Police). 83. San Salvador: Imprenta Public.

Ford, D. A., \& Regoli M. J. (1993). The Criminal Prosecution of Wife Assaulters. Legal Responses to Wife Assault, 127-64. Newbury Park, CA: Sage.

Ford, J., Rompf, E. L., Faragher, T., \& Weisenfluh, S. (1995). Case outcomes in domestic violence court: Influence of judges. Psychological Reports, 77(2), 587-594. doi:10.2466/pr0.1995.77.2.587

Fradella, H. F., \& Fischer, R. G. (2010). Factors impacting sentence severity of intimate partner violence offenders and justification for the types of sentences imposed by mock judges. Law and Psychology Review, 34 (25). 
Frantzen, D., \& San Miguel, C. (2009). Mandatory arrest? Police response to domestic violence victims. Policing: An International Journal of Police Strategies \& Management, 32(2), 319-337. doi:10.1108/13639510910958208

Frantzen, D., San Miguel, C., \& Kwak, D. (2011). Predicting case conviction and domestic violence recidivism: Measuring the deterrent effects of conviction and protection order violations. Violence and Victims, 26(4), 395-409. doi:10.1891/0886-6708.26.4.395

Friday, P.C., Metzgar, S., \& Walters, D. (1991) Policing domestic violence: Perceptions, experience, and reality. Criminal Justice Review, 16 (2), 198-213.

Friedman, L. N. \& Shulman, M. (1990). Domestic Violence: The criminal justice response: In Lurigion, A. J., Skogan W. G., \& Davis R. C. (Eds.), Victims of crime: Problems, policies, and programs (pp. 87-103). Newbury Park, CA: Sage.

Galanter, M. (1974). Why the "Haves" come out ahead: Speculations on the limits of legal change. Law and Society Review, 9 (1). Reprinted (with corrections) in Cotterrell R. (Ed.) Law and Society, Aldershot, Dartmouth, 1994, pp. 165-230.

Galvão, E. F. \& Andrade, S. M. (2004). Violência contra mulher: análise de casos atendidos em serviço de atenção á mulher no município do Sul do Brasil. Saúde e Sociedade, Londrina, $13,89-99$.

Ganapathy, N. (2006). The operational policing of domestic violence in Singapore: An exploratory study. International Criminal Justice Review, 16(3), 179-198.

Garcia, V., \& McManimon, P. M. (2011). Gendered justice: Intimate partner violence and the criminal justice system. Lanham: MD: Rowman \& Littlefield Publishers.

Garner, J. \& Clemmer, E. (1986). Danger to police in domestic disturbances - A New Look. Research in brief. Washington D.C.: U.S. Department of Justice. 
Garner, J. H., \& Maxwell, C. D. (2009). Prosecution and conviction rates for intimate partner violence. Criminal Justice Review, 34(1), 44.

Gershman, B. L. (1993). A moral standard for the prosecutor's exercise of the charging discretion. Fordham Urban Law Journal, 20(3), 513.

Gillespie, C. K. (1989). Justifiable homicide: Battered women, self-defense, and the law. Columbus: Ohio State University Press.

Glick, H. R. (1971). Supreme courts in state politics: An investigation of the judicial role. New York: Basic Books.

Goldberg, M. A. A. (1985). Violência contra a mulher. São Paulo: Comissão de Violência do Conselho Estadual da Condição Feminina.

Goodman, L., Bennett L., \& Dutton, M. A. (1999). Obstacles to Victims' Cooperation With the Criminal Prosecution of Their Abusers: The Role of Social Support. Violence and Victims, 14, 427-44.

Gordon, L. (1988). Heroes of Their Own Lives: The Politics and History of Family Violence. New York: Penguin.

Gover, A. R., MacDonald, J. M., \& Alpert, G. P. (2003). Combating domestic violence: Findings from an evaluation of a local domestic violence court. Criminology \& Public Policy, 3(1), 109-132. doi:10.1111/j.1745-9133.2003.tb00028.x

Grau, J., Fagan, J., \& Wexler, S. (1985). Restraining orders for battered women: Issues of access and efficacy. Women and Politics, 4, 13-28.

Gregori, M. (1993). Cenas e queixas: um estudo sobre mulheres, relações violentas e a prática feminista. São Paulo: Paz e Terra.

Gregori, M. (2006). Delegacias de defesa da mulher de São Paulo: para- doxos e paralelismos. 
Gênero e distribuição da justiça: as delegacias de defesa da mulher e a construção das diferenças. 57-87.

Grossi, M. P. (1988). Discours sur les femmes battues: représentations de la violence sur les femmes au Rio Grande do Sul. Tese de doutorado: Universidade de Paris V.

Hague, G., \& Mullender, A. (2006). Who listens? the voices of domestic violence survivors in service provision in the united kingdom. Violence Against Women, 12(6), 568-587. doi: $10.1177 / 1077801206289132$

Hajjar, L. (2004). Religion, state power, and domestic violence in Muslim societies: A framework for comparative analysis. Law \& Social Inquiry, 29(1), 1-38. Doi: 10.1111/j.1747-4469.2004.tb00329.x

Hamilton, M. (2009). Expert testimony on domestic violence: A discourse analysis. El Paso: LFB Scholarly Pub.

Hanna, C. (2002). Domestic Violence. Encyclopedia of Crime and Justice. http://www.encyclopedia.com/topic/Domestic_violence.aspx

Harrell, A., Smith, B., \&a Newmark, L. (1993). Court Processing and the Effects of Restraining Orders for Domestic Violence Victims. Washington, DC: Urban Institute.

Harrington, P. A., \& Wimmer, J. S. (2008). Domestic violence services in romania: A longitudinal case study. International Social Work, 51(5), 623-633. Doi: $10.1177 / 0020872808093341$

Hartley, C. C. (2003). A therapeutic jurisprudence approach to the trial process in domestic violence felony trials. Violence Against Women 9(4), 410. 
Hartman, J. \& Belknap, J., (2003). Beyond the gatekeepers: Court professionals'self-reported attitudes about and experiences with domestic violence cases." Criminal Justice \& Behavior, 30(3), 349-373.

Hautzinger, S. (2007), Violence in the City of Women: Police and Batterers in Bahia, Brazil. Berkeley: University of California Press.

Hawkings, D. \& Humes, M. (2002). Human rights and domestic violence. Political Science Quarterly, 117.2, 231-257.

Hays, S. W. (1978). Court Reform: Ideal or Illusion? Lexington, MA: D.C. Heath and Co.

Hearn, J., \& McKie, L. (2010). Gendered and social hierarchies in problem representation and policy processes: "domestic violence" in Finland and Scotland. Violence Against Women, 16(2), 136-158. Doi: 10.1177/1077801209355185

Henning, K., \& Feder, L. (2005). Criminal prosecution of domestic violence offenses: An investigation of factors predictive of court outcomes. Criminal Justice and Behavior, 32(6), 612-642.

Hermann, J. \& Barsted, L. L. (1995). O Judiciário e a Violência contra a Mulher: A Ordem Legal e a (des) Ordem Familiar. Rio de Janeiro: CEPIA.

Heumann, M. (1978). Plea Bargaining: The Experiences of Prosecutors, Judges, and Defense Attorneys. Chicago: University of Chicago Press.

Hickman, L. J. \& Simpson S. S. (2003). Fair treatment or preferred outcome? The impact of police behavior on victim reports of domestic violence incidents. Law and Society Review, 37, 607-827.

Hilton, Z. (1993). Legal responses to wife assault: Current trends and evaluation. Newbury Park: Sage. 
Hines, D. A., \& Malley-Morrison, K. (2005). Family violence in the united states: Defining, understanding, and combating abuse. Thousand Oaks, Calif: Sage Publications.

Hirschel, J. D. \& Hutchinson, I. W. (1991). Police-preferred arrest policies. Battered women: Policy responses, 49-72.

Hirschel, J. D., Hutchinson, I. W., \& Dean, C. W. (1992). The failure of arrest to deter spouse abuse. Journal of Research in Crime and Delinquency, 29(1), 7-33.

Hirschel, J. D., \& Hutchison, I.W. (1996). Realities and implications of the Charlotte experiment. In E. S. Buzawa \& C. G. Buzawa (Eds.), do arrests and restraining orders work? (pp. 5482). Thousand Oaks, CA: Sage.

Hirschel, D., \& Hutchison, I. W. (2001). The relative effects of offense, offender, and victim variables on the decision to prosecute domestic violence cases. Sage Publications, Inc.

Hirschel, D., Buzawa, E., Pattavina, A., \& Faggiani, D. (2008). Domestic violence and mandatory arrest laws: To what extent do they influence police arrest decisions? Journal of Criminal Law \& Criminology, 98 (1), 255-298.

Horwitz, S. H., Mitchell, D., LaRussa-Trott, M., Santiago, L., Pearson, J., Skiff, D. M., \& Cerulli, C. (2011). An inside view of police officers' experience with domestic violence. Journal of Family Violence, 26(8), 617-625.

Hoyle, C. 2000. Police response to domestic violence. British Journal of Criminology, 40(1), 1436.

Htun, M. (2002). Puzzles of Women's Rights in Brazil. 4 (2002). Retrieved from http://www.findarticle.com (accessed August 2, 2013). 
Htun, M. \& Power, T. J. (2006), Gender, Parties, and Support for Equal Rights in the Brazilian Congress. Latin American Politics and Society, 48: 83-104. doi: 10.1111/j.15482456.2006.tb00366.x

Human Rights Watch. (2012). World Report 2012. New York: Human Rights Watch. Hynson v. City of Chester, PA, 864 F.2d 1026, 1032 (3d Cir.1988)

IBGE - Instituto Brasileiro de Geografia e Estatística. (2008). Síntese dos Indicadores Sociais: uma análise das condições de vida da população brasileira. Retrieved from: $<$ http://www.ibge.gov.br/home/>.

IBGE - Instituto Brasileiro de Geografia e Estatística. (2009). Pesquisa de Informações Básicas Municipais. Perfil dos Municípios Brasileiros - MUNIC. Rio de Janeiro: IBGE.

IBOPE. (2009). Percepções sobre a violência doméstica contra a mulher no Brasil. Instituto Avon.

Izumino, W. P. (1998). Justiça e Violência Contra a Mulher. O papel do Sistema Judiciário na solução dos conflitos de gênero. São Paulo: FAPESP/Annablume.

Izumino, W. P. (2003). Justiça para todos: Os juizados especiais criminais e a violência de gênero. Tese de doutorado, Faculdade de Filosofia, Letras e Ciências Humanos, Programa de Pós-graduação em Sociologia, Universidade de São Paulo. (versão eletrônica disponível em: www.nevusp.org.br/publicacoes)

Jacob, H. (1983). Courts as organizations. In Boyum K. O., \& Mather, L. (Eds.), Empirical theories about courts. New York, NY: Longman, Inc.

Jacob, H. (1997). The governance of trial judges. Law \& Society Review, 31(1), 3-30.

Jaquette, J.S. (1994) The Women's Movement in Latin America: Participation and Democracy, Boulder, CO: Westview Press. 
Jenkins, P. (1996). Threads that link community and family violence: Issues for prevention. In R. L. Hampton, P. Jenkins and T. P. Gullotta (Eds.), Preventing violence in America (pp. 33-52). London: Sage.

Johnson, I., Sigler, R., \& Crowley, J. (1994). Domestic violence - A comparative study of perceptions and attitudes toward domestic abuse cases among social-service and criminal-justice professionals. Journal of Criminal Justice, 22(3), 237-248.

Johnson, I. M. (2007). Victims' perceptions of police response to domestic violence incidents. Journal of Criminal Justice, 35(5), 498-510.

Johnson, R. R. (2010). Making domestic violence arrests: A test of expectancy theory. Policing: An International Journal of Police Strategies \& Management, 33(3), 531-547.

Jolin, A., \& Moose, C. A. (1997). Evaluating a domestic violence program in a community policing environment: Research implementation issues. Crime \& Delinquency, 43(3), 279-297. Doi: $10.1177 / 0011128797043003003$

Jubb, N. (2001). Enforcing Gender Meanings and Social Order: The Participation of the national Police in the Nicaraguan Comisarías de la Mujer y la Niñez. Paper presented at the Congress of Latin American Studies Association (LASA), Washington, D.C.

Jubb, N., \& Izumino, W.P. (2003). Women and Policing in Latin America: A Revised Background Paper. Prepared for delivery at the 2003 meeting of the Latin American Studies Association. Dallas, Texas. Texto não publicado.

Juiz considera lei Maria da Penha inconstitucional e diabolica (2007). Folha Online. Folha de S. Paulo. Retrieved from http://www1.folha.uol.com.br/cotidiano/2007/10/338430-juizconsidera-lei-maria-da-penha-inconstitucional-e-diabolica.shtml 
Kaci, J. H., \& Tarrant, S. (1988). Attitudes of prosecutors and probation departments toward diversion in domestic violence cases in california. Journal of Contemporary Criminal Justice, 4(3), 187-200. Doi: 10.1177/104398628800400306

Kane, R. J. (2000). Police responses to restraining orders in domestic violence incidents: Identifying the custody-threshold thesis. Criminal Justice and Behavior, 27(5), 561-580. Doi: $10.1177 / 0093854800027005002$

Keilitz, S. L. (2000). Specialization of domestic violence case management in the courts: A national survey. National Center for State Courts, \& National Institute of Justice (U.S.) Williamsburg, Va.: National Center for State Courts.

Kelly, J. B., \& Johnson, M. P. (2008). Domestic violence: differentiation among types of intimate partner violence: research update and implications for interventions. Family Court Review, 46, 476-670.

Kemp, C., Norris, C., \& Nigel G. F., (1992). Negotiating nothing: police decision making in disputes. Aldershot; Brookfield, Vt., USA: Avebury, c1992.

Kern, R., Libkuman, T. M., \& Temple, S. L. (2007). Perceptions of domestic violence and mock jurors' sentencing decisions. Journal of Interpersonal Violence, 22(12), 1515-1535. Doi: $10.1177 / 0886260507306476$

Kimani, M. (2007). Taking on violence against women in Africa: International norms, local activism start to alter laws, attitudes. Africa Renewal, 21(2), 4.

King, M., \& Batagol, B. (2010). Enforcer, Manager or Leader? The Judicial Role in Family. Violence Courts. Int'l JL \& Psychiatry, (33), 406. 
Kingsnorth, R.F., MacIntosh R., \& Wentworth, J. (1999). Sexual assault: The role of prior relationship and victim characteristics in case processing." Justice Quarterly, 16, 275302.

Kingsnorth, R., \& Macintosh, R. (2004). Domestic violence: Predictors of victim support for official action. Justice Quarterly, 21(2), 301-328. Doi: 10.1080/07418820400095821

Kirsh, T. (2001). Problems in domestic violence: should victims be forced to participate in the prosecution of their abusers? William and Mary Journal of Women and the Law, 7, 3831011.

Kritzer, H. M., \& Zemans, F. K. (1993). Local legal culture and the control of litigation. Law and Society Review, 27(3), 535.

Lamb, S., \& Keon, S. (1995). Blaming the perpetrator: Language that distorts reality in newspaper articles on men battering women. Psychology of Women Quarterly, 19, 209220.

Larrain, S. (1997). Relaciones familiares y Maltrato Infantil. Chile: Editorial Calicanto.

LaViolette, A., \& Barnett, O. (2000). It could happen to anyone: Why battered women stay. Thousand Oaks, CA: Sage.

Lavoie, F., Jacob, M., Hardy J., \& Martin, G. (1989). Police attitudes in assigning responsibility for wife abuse. Journal of Family Violence, 4, 369-387.

Lazarus-Black, M. (2001). Law and the pragmatics of inclusion: Governing domestic violence in Trinidad and Tobago. American Ethnologist, 28(2), 388-416.

Lazarus-Black, M. (2007). Everyday harm: Domestic violence, court rites, and cultures of reconciliation. Urbana: University of Illinois Press. 
Leighton, B. (1989). Spousal abuse in metropolitan Toronto: Research report on the response of the criminal justice system (No. 1989-02). Ottawa, Ontario: Solicitor General of Canada.

Lempert, R. (1989). Humility is a virtue: On the publicization of policy relevant research. Law and Society Review, 23, 145-161.

Lerman, L. G. (1981). Prosecution of spouse abuse innovations in criminal justice response. Washington, DC: Center for Women's Policy Studies.

Lerman, L. G. (1992). The decontextualization of domestic violence. Journal of Criminal Law and Criminology, 83 (1), 217-240.

Lewis, R., Dobash R. E., Dobash R. P., \& Cavanagh, K., (2001). Law’s Progressive Potential: The Value of Engagement with the law for domestic violence. Social Legal Studies, 10 (1), 105-130; Sage Publications, London, Thousand Oaks, CA and New Delhi.

Lewis, R. (2004). Making justice work: Effective legal interventions for domestic violence. British Journal of Criminology, 44(2), 204-224.

Liebman, D. A., \& Schwartz, J. (1973). Police programs in domestic crisis intervention: A review. In Snibbe J. R., \& Snibbe H. M. (Eds.), The urban policeman in transition, 421472. Springfield, Ill.: Charles C. Thomas.

Lightman, L. M. A., \& Byrne F. (2005). Courts responding to domestic violence: Addressing the co-occurrence of domestic violence and substance abuse: Lessons from problem-solving courts. Journal of the Center for Families, Children \& the Courts, 6, 53-175.

Lockhart, L. L., \& Danis, F. S. (2010). Domestic violence: Intersectionality and culturally competent practice. New York: Columbia University Press. 
Logan, T., Walker, R., \& Leukefeld, C. (2001). Rural, urban influenced and urban differences among domestic violence arrestees in Kentucky. Journal of Interpersonal Violence, 16, 266-283.

Logan, T., Shannon, L., \& Walker, R. (2006). Police attitudes toward domestic violence offenders. Journal of Interpersonal Violence, 21, 1365-1374.

Lutze, F. E., \& Symons, M. L. (2003). The evolution of domestic violence through masculine institutions: From discipline to protection to collaborative empowerment. Criminology \& Public Policy, 2(2), 319-328.

Macaulay, F. (2006), “Difundiéndose hacia arriba, hacia abajo y hacia los lados: políticas de género y oportunidades políticas en Brasil”, in Natalie Lebon e Elizabeth Maier (orgs.), De lo privado a lo público: 30 años de lucha ciudadana de las mujeres en América Latina. México: Siglo XXI - UNIFEM: LASA, 331-345.

MacDowell, E. L. (2011). When courts collide: Integrated domestic violence courts and court pluralism. Texas Journal of Women and the Law, 20(2), 95.

Martin, D. (1981). Battered wives (Rev. ed.). San Francisco: Volcano Press.

Martin, J. (1983). Maternal and paternal abuse of children: theoretical and research perspectives In Finkelhor, D., Gelles R. J., Hotaling G. T., \& Straus, M. A. (Eds.). The Dark Side of Families: Current Family Violence Research, 293-304 Beverly Hills, CA Sage.

Martin, M. E. (1994). Mandatory arrest for domestic violence: The courts' response. Criminal Justice Review, 19(2), 212-227.

Martin, M. E. (1997a). Policy promise: Community policing and domestic violence victim satisfaction. Policing: An International Journal of Police Strategies \& Management, 20(3), 519-531. Doi: 10.1108/13639519710180187 
Martin, M. E. (1997b). Double your trouble: Dual arrest in family violence. Journal of Family Violence, 12, 139-157.

Mather, L. M. (1979). Comments on the history of plea bargaining. Law \& Society Review, 13(2), 281-285.

Mauleón, C. O. (1998) Encuentros, (Des) encuentros y búsquedas: El movimiento feminista en América Latina. Lima: Ediciones Flora Tristán.

Mazur, R., \& Aldrich, L. (2003). What makes a domestic violence court work? lessons from New York. Judges Journal, 42(2), 4.

McCord, E. S., Ross, J. W., \& Worrall, J. L. (2006). Modeling prosecutors' charging decisions in domestic violence cases. Crime \& Delinquency, 52(3), 472-503.

McLeod, M. (1983). Victim Noncooperation in the Prosecution of Domestic Assault. Criminology, 21,395-416.

Meneghel, S., \& Hirakata, V. (2011). Femicides: Female homicide in brazil. Revista De Saude Publica, 45(3), 564-574.

Merry, S. E. (1995). Gender violence and legally engendered selves. Identities: Global Studies in Culture and Power, 2(1-2), 49-73.

Mignon, S. I., \& Holmes, W. M. (1995). Police response to mandatory arrest laws. Crime and Delinquency, 41 (4), 399-413.

Miller, S. L. (2001). The paradox of women arrested for domestic violence: Criminal justice professionals and service providers respond. Violence Against Women, 7, 12, 1339-1376.

Minayo M. C. S. (1994). Inequality, violence, and ecology in Brazil. Cad Saude Pública. 10(2), 241-50. Doi: 10.1590/S0102-311X1994000200011 
Mirchandani, R. (2006). "Hitting is not manly": Domestic violence court and the re-imagination of the patriarchal state. Gender and Society, 20(6), 781-804. Doi:

$10.1177 / 0891243206292002$

Muniz, J. (1996). Os direitos dos outros e os outros direitos: um estudo sobre a negociação de conflitos nas DEAMs/RJ. In Soares. L. E. (org.), Violência e política no Rio de Janeiro. Rio de Janeiro: ISER/Relume Dumará, 125-163.

Myers, M. A., \& Hagan J. (1979). Private and public trouble: Prosecutors and the allocation of court resources. Social Problems, 26 (Apri14), 439-451.

Nader, M. B. (2007). Violência sutil contra a mulher: Manifestações históricas. In: NADER, M. B., \& Lima, L. L. G (orgs). Família, Mulher e Violência. Vitória: PPGHIS, 2007. Coleção Rumos da História, 9 - 17.

Nader, M. B. (2009). Cidades, aumento demográfico e violência contra a mulher: O ilustrativo caso de Vitória - ES. Revista Dimensões, 23. Programa de Pós-Graduação em História UFES. 2009. Disponível em: www.ufes.br/ppghis/dimensoes

Narayanan, G. (2005). Theorizing police response to domestic violence in the Singaporean context: Police subculture revisited. Journal of Criminal Justice, 33(5), 429-439.

Nardulli, P. (1978). The Courtroom Elite. Cambridge, Mass.: Ballinger Publishing Co.

Nardulli, P., Eisenstein, J., \& Flemming, R. B. (1988). The tenor of justice: Criminal courts and the guilty plea process. Urbana: University of Illinois Press.

Nelson, S. (1996). Constructing and negotiating gender in women's police stations in Brazil. Latin American Perspectives, 23(1), 131-148.

Nicolson, D. (1995). Telling tales: Gender discrimination, gender construction and battered women who kill. Feminist Legal Studies, 3, 185-206. 
Niemi-Kiesilainen, J. (2001). The deterrent effect of arrest in domestic violence: differentiating between victim and perpetrator response. Hastings Women's Law Journal, 12, 283-387.

Observe: Observatório da Lei Maria da Penha. (2010). Condições para aplicação da Lei 11.340/2006 (Lei Maria da Penha) nas Delegacias Especializadas de Atendimento à Mulher (DEAMS) e nos Juizados de Violência Doméstica e Familiar nas capitais e no Distrito Federal. Salvador, BA.

Observe: Observatório da Lei Maria da Penha. (2011). Identificando entraves na articulação dos serviços de atendimento às mulheres vítimas de violência doméstica e familiar em cinco capitais. Salvador, BA.

Oliveira, M. B. de (2008). Da delegacia de defesa da mulher ao Juizado Especial Criminal: Significados da violência de gênero no fluxo procesual. In Debert, G. G., Gregori, M. F., \& de Oliveira M. B. (orgs.), Gênero, família e gerações: Juizado Especial Criminal e Tribunal de Júri. Campinas: Pagu/Núcleo de Estudos de Gênero, UNICAMP, 15-49.

Pami V. (2006). Reconceptualizing domestic violence in India: Economic abuse and the need for broad statutory interpretation to promote women's fundamental rights. Michigan Journal of Gender \& Law, 13(1), 177.

Pandjiarjian, V. (2006), Balanço de 25 anos da legislação sobre a violência contra as mulheres no Brasil. In Diniz, C. S. G., Da Silveira, L. P., \& Mirian L. A. L. (orgs.). Vinte e cinco anos de respostas brasileiras em violência contra a mulher (1980-2005): alcances e limites. São Paulo: Coletivo Feminista Sexualidade e Saúde, 78-139.

Parnas, R. I. (1967). The police response to domestic disturbance. Wisconsin Law Review, 2, 914-960.

Pasinato, W., \& Santos, C. M. (2008). Mapeamento das Delegacias da Mulher no Brasil. Núcleo 
de Estudos de Gênero Pagu. Campinas, 38.

Pasinato, W., \& Santos, C. M. (2009). Violência, gênero e acesso a justiça. Contribuições da Delegacia Especial de Crimes Contra a Mulher e da Rede de Enfrentamento a Violência de Minas Gerais. Belo Horizonte, Minas Gerais. Documento Final. Brasil, 171.

Pasinato, W. (2010). Lei maria da penha: Novas abordagens sobre velhas propostas. Onde avançamos? Civitas, 10(2), 216-232.

Pate, A. M., \& Hamilton, E. E. (1992). Formal and informal deterrents to domestic violence: The Dade County Spouse Assault Experiment. American Sociological Review, 57, 691-697.

Paulo, R. (2011). Violência contra mulher em Vila Velha continua crescendo. Gazeta Online. Retrieved from http://gazetaonline.globo.com/_conteudo/2011/06/noticias/especiais/889886-violenciacontra-mulher-em-vila-velha-continua-crescendo.html

Pinto, C. R. J. (2003). Uma história do feminismo no Brasil. São Paulo: Editora Fundação Perseu Abramo.

Pitanguy, J. (1990). Políticas Públicas y Ciudadania. In: Transiciones, Mujeres en los Procesos Democráticos, ISIS Internacional, Santiago, Chile.

Pleck, E. (1987). Domestic tyranny: The making of American social policy against family violence from the colonial times to the present. New York: Oxford University Press.

Pleck, E. (1989). Criminal approaches to family violence, 1640-1980. In Ohlin L. \& Tonry M. (Eds.), Family violence. Crime and justice: A review of research, 11, 19-57. Chicago: University of Chicago Press.

Pougy, L. G. (2010). Desafios políticos em tempos de lei maria da penha. Revista Katálysis, 13(1). 
Prescott, D. E. (2009). Unified family courts and the modern judiciay as a "street-level bureaucracy": To what end for the "mythical" role of judges in a democracy. Quinnipiac Law Review, 27, 55-112.

Pruitt, L. R. (2008). Place matters: Domestic violence and rural difference. Wisconsin Journal of Law, Gender \& Society, 23, 347-347.

Ptacek, J. (1999). Battered women in the courtroom: The power of judicial responses. Boston: North- Eastern University Press.

Rebovich, D. J. (1996) Prosecution response to domestic violence: Results of a survey of large jurisdictions. Do Arrests and Restraining Orders Work? Thousand Oaks, CA: Sage.

Reiss, A. J., \& Black, D. J. (1967). Studies in crime and law enforcement in major metropolitan areas, 3(3). Office of Law Enforcement Assistance. Washington: U.S. Govt. Print.

Rempel, M., Labriola, M., \& Davis, R. C. (2008). Does judicial monitoring deter domestic violence recidivism? Results of a quasi-experimental comparison in the Bronx. Violence Against Women, 14(2), 185.

Rich, R. (2002). Solidarity rights give way to solidifying rights. Dialogue, 21(3), 25.

Richie, B. E., \& Kanuha, V. (1993). Battered women of color in public health care systems: Racism, sexism, and violence. In B. Bair \& S. E. Cayleff (Eds.), Wings of gauze: Women of color and the experience of health and illness (pp. 288-299). Detroit, MI: Wayne State University.

Richie, B. E. (1996). Compelled to crime: The gender entrapment of battered Black women. New York: Routledge. 
Rifiotis, T. (2001). Entrenching Women's Police Stations in Law: Police Scenarios and Practices. Policing in Democratic Societies, Police and Women: Historical and Contemporary Problems. 1 (6), 26-27.

Rifiotis, T. (2004). As delegacias especiais de proteção à mulher no Brasil e a "judiciarização" dos conflitos conjugais. In: Sociedade e Estado. Violências e Conflitualidades. Revista do Departamento de Sociologia da UnB, Brasília, 19 (1), 90-115.

Roberts, A. R. \& Fields, M. D. (2002). Handbook of domestic violence intervention strategies: Policies, programs, and legal remedies. New York: Oxford University Press, Incorporated.

Robinson, A. (2000). The effect of domestic violence policy change on police officer's schemata. Criminal Justice and Behavior, 27 (5), 600-624.

Rotimi, A. (2007). Violence in the Family: A Preliminary Investigation and Overview of Wife Battering in Africa. Journal of International Women's Studies, 9 (1), 234-252.

Roure, J. G. (2009). Domestic violence in Brazil: Examining obstacles and approaches to promote legislative reform. Columbia Human Rights Law Review, 41(1), 67.

Rowe, M. (2007). Rendering visible the invisible: Police discretion, professionalism and decision-making. Policing and Society, 17, 279-294.

Roy, M. (1977). A current survey of 150 cases. Battered women, 25-44. New York: Van Nostrand Reinhold.

Russell, M., \& Light, L. (2006). Police and victim perspectives on empowerment of domestic violence victims. Police Quarterly, 9(4), 375-396. Doi: 10.1177/1098611104264495

Santos, C. M. (1999). Cidadania de gênero contraditória: queixas, crimes e direitos na Delegacia da Mulher em São Paulo. In Amaral Jr, A. \& Perrone-Moisés, C. (orgs.). $O$ 
cinquentenário da Declaração Universal dos Direitos do Homem. São Paulo: Edusp, 315-352.

Santos, C. M. (2005). Women's police stations: Gender, violence, and justice in Sao Paulo, Brazil. New York: Palgrave Macmillan.

Santos, C. M. (2007). Transnational legal activism and the state: Reflections on cases against brazil in the inter-american commission on human rights. International Journal of Human Rights, (7), 29-59.

Santos, C. M. (2008). Da delegacia da mulher à Lei Maria da Penha: lutas feministas e políticas públicas sobre violência contra mulheres no Brasil. Oficina do CES, 301.

Santos, C. M. (2010). From women's police stations to the maria da penha law: The state's absorption/translation of women's demands. Revista Critica De Ciencias Sociais, (89), 153-170.

Sardenberg, C., Gomes, M., \& Tavares, M. (2010). A aplicação da Lei Maria da Penha em Foco. Salvador: NEIM/UFBA.

Schechter, S. (1982). Women and male violence: The visions and struggles of the battered women's movement. Boston: South End.

Schmidt, J., \& Steury, E. H. (1989). Prosecutorial Discretion in Filing Charges in Domestic Violence Cases. Criminology, 27:487-510.

Schneider, E. M. (2000). Battered women \& feminist lawmaking. New Haven: Yale University Press.

Scott v. Hart, No. C-76-2395 (N.D. Cal., filed Oct. 28, 1976).

Secretaria Especial de Políticas para as Mulheres (2007). Enfrentamento à violência contra a mulher. Balanço das ações 2006-2007. Brasília: Secretaria Especial de Políticas para 
Mulheres/Presidência da República.

Shaffer, H. C. (2004). Therapeutic domestic violence courts: An efficient approach to adjudication? Seattle University Law Review, 27, 981-1063.

Shahidullah, S. M., \& Derby, N. C. (2009). Criminalisation, modernisation, and globalisation: The US and international perspectives on domestic violence. Global Crime, 10(3), 196223. Doi: $10.1080 / 17440570903079923$

Shenoy, M. (2007). Domestic violence: Issues and perspectives: Issues and perspectives. New Delhi: Aavishkar Publishers.

Sherman, L., \& Cohen, E. G. (1987). The impact of research on legal policy: The Minneapolis domestic violence experiment. Law and Society Review, 23, 117-144.

Sherman, L., \& Berk, R.S. (1984). The Specific Deterrent Effects of Arrest for Domestic Assault. American Sociological Review, 49, 261-72.

Sherman, L. (1992). The Influence of Criminology on Criminal Law: Evaluating for Misdemeanor Domestic Violence. Journal of Criminal Law and Criminology, 85, 90145.

Shuman Jr., R. D., McCauley, J., Waltermaurer, E., Roche III, W. P., Hollis, H., \& Gibbons, A. K. (2008). Understanding intimate partner violence against women in the rural south. Violence \& Victims, 23(3), 390-405.

Silva, K. C. (2004). As DEAM, as corporações policiais e a violência contra as mulheres: Representações, dilemas e desafios. In: Relatório Final da Pesquisa Nacional sobre as Condições de Funcionamnto das Delegacias Especializadas no Atendimento às Mulheres. Retrieved from http://www.cfemea.org.br/temasedados/detalhes.asp?IDTemasDados=1 
Soares, L. E, Soares, B. M., \& Carneiro, L. P. (1996). Violência contra a mulher: as DEAMS e os pactos domésticos. In Soares, L.E. et al. Violência e política no Rio de Janeiro. Mulheres invisíveis: Violência conjugal e novas políticas de segurança. Rio de Janeiro: Civilização Brasileira.

Sorenson, S. B., \& Vittes, K. A. (2006). Are temporary restraining orders more likely to be issued when applications mention firearms? Evaluation Review, 30(3), 266-282. Doi:

\section{$10.1177 / 0193841 X 06287403$}

Souza, L. D., \& Cortez, M. B. (2014). Women's defense police station towards the rules and laws for combating violence against women: A case study. Revista De Administração Pública, $48(3), 621$.

Spears, J.W., \& Spohn, C. C. (1997). The effect of evidence factors and victim characteristics on prosecutors' charging decisions in sexual assault cases. Justice Quarterly, 14, 501-24

Spohn, C., Beichner, D., \& Davis-Frenzel, E. (2001). Prosecutorial justifications for sexual assault case rejection: Guarding the "gateway to justice." Social Problems, 48, 206-235.

Stalans, L. J., \& Finn, M. A. (2000). Gender differences in officer's perceptions and decisions about domestic violence cases. Women \& Criminal Justice, 11, 1-24.

Stalans, L. J., \& Finn, M. A. (2006). Public's and police officers' interpretation and handling of domestic violence cases: Divergent realities: Divergent realities. Journal of Interpersonal Violence, 21(9), 1129-1155.

State v. Smith, 85 N.J. 193 (1981) 426 a. 2 d 38

Steady, F. (2006) Women and collective action in Africa: Development, democratization, and empowerment, with special focus on Sierra Leone. New York: Palgrave Macmillan. 
Suk, J. (2009). At home in the law: How the domestic violence revolution is transforming privacy. New Haven: Yale University Press.

Sun, I. Y. (2007). Policing domestic violence: Does officer gender matter? Journal of Criminal Justice, 35(6), 581-595.

Tamayo, C. (1998). Entre la Sombra y la Esperanza: Investigación de impacto de las Comisarías de la Mujer y la Familia. Quito: Centro Ecuatoriano de Promoción y Acción de la Mujer (CEPAM).

Tamayo, G. (2000) Derechos humanos de las mujeres, violencia contra la mujer y paz en la región: Revisión de avances y desafios a cinco años de la Cuarta Conferencia Mundial sobre la Mujer. Informe preparado para Algo más que palabras. Mecanismos, recursos y justicia de género en el siglo XXI. Reunión Regional de ONGs de América Latina y el Caribe hacia Beijing +5 , Lima, Peru.

Taylor C. (1995). Northern Ireland: The policing of domestic violence in nationalist communities. Wisconsin Women's Law Journal, 10, 307-403.

Taylor, M. M. (2008). Judging Policy: Courts and Policy Reform in Democratic Brazil. Stanford: Stanford University Press.

The Massachusetts Body of Liberties (1641). Hanover Historical Texts Project.

Thomas, D. (1992). Injustiça Criminal X Violência contra a Mulher no Brasil, Americas Watch/Human Rights.

Thurman v. City of Torrington, DC, 595 F. Supp. 1521 (D. Conn. 1984)

Tobin, R. (1999). Creating the judiciary: The unfinished reform. NCSC.

Torres S., Ileana, I. Q. S., \& Cuadra. J. V. (2000). Diagnóstico del uso de arreglos extrajudiciales en las comisarías de la mujer y la niñez, Policía Nacional. 
Trujillo, M. P., \& Ross, S. (2008). Police response to domestic violence: Making decisions about risk and risk management. Journal of Interpersonal Violence, 23, 454.

U.S. Commission on Civil Rights (1982). Under the Rule of Thumb: Battered Women and the Administration of Justice.

Ulmer, J. T. (1997). Social worlds of sentencing: Court communities under sentencing guidelines. Albany: State University of New York Press.

Ulmer, J. T., \& Kramer, J. H. (1998). The use and transformation of formal decision-making criteria: Sentencing guidelines, organizational contexts, and case processing strategies. Social Problems, 45(2), 248-267. Doi: 10.2307/3097246

United Nations. (2000). The World's Women 2000. New York: United Nations.

United Nations. (2006a). Ending Violence Against Women: From Words to Action. Study of the Secretary-General, New York: UN.

United Nations. (2006b). Agreed Conclusions of the Commission on the Status of Women on the Critical Areas of Concern of the Beijing Platform for Action 1996-2005. Department of Economic and Social Affairs, Division for the Advancement of Women. New York: United Nations.

Ursel, E. J. (2002). "His sentence is my freedom": Processing domestic violence cases in the Winnipeg Family Violence Court. In Tutty L., \& Goard C. (Eds.). Reclaiming self: Issues and resources for women abused by intimate partners, 43-63. Halifax, NS: Fernwood.

Ursel, J. (1995). Winnipeg Family Violence Court Evaluation.Working Document WD1995-2e, Department of Justice, Ottawa, Canada. 
Vyas, P. (2006). Reconceptualizing domestic violence in India: Economic abuse and the need for broad statutory interpretation to PROMOTE women's fundamental rights. Michigan Journal of Gender \& Law, 13, 177.

Waiselfisz, J. J. (2011). Mapa da Violência. Os novos padroes da violência homicida no Brasil. São Paulo, Brazil: Instituto SANGARI.

Waiselfisz, J. J. (2012). Mapa da Violência 2012: criancas e adolescentes no Brasil. Rio de Janeiro: Cebela/Flacso.

Walker, J. (1981). Police in the middle: A study of small city police interventions in domestic disputes. Journal of Police Science and Administration, 9, 243-260.

Walker, L. (1979). The Battered Woman. New York: Harper and Row.

Wallace, H. (1996). Family violence. Needham Heights, MA: Allyn Bacon.

Walsh, K. (1995). Domestic violence and the law symposium: The mandatory arrest law: Police reaction. Pace Law Review, 16, 97-607.

Watson v. City of Kansas City, 857 F.2d 690; (10th Cir. 1988) Lexis 12640.

Waylen, G. (1996). Gender in Third World Politics. Boulder: Lynne Rienner.

Waylen, G. (2002). Radical women in Latin America: Left and right. American Political Science Review, 96(2), 439-440. Doi: 10.1017/S0003055402670248

Wermuth, L. A. (1983). Wife beating: The crime without punishment. Doctoral dissertation, University of Califorina, Berkley.

White, M. D., Goldkamp, J. S., \& Campbell, S. P. (2005). Beyond mandatory arrest: Developing a comprehensive response to domestic violence. Police Practice \& Research: An International Journal, 6, 261-278. 
Wilson, C., Martinez, J., \& Huisman, K. (2005). Training police officers on domestic violence and racism: Challenges and strategies. Violence Against Women, 11(6), 792-821. doi: $10.1177 / 1077801205276110$

World Health Organization-WHO. (2005). World report on violence and health. Geneva.

World Health Organization-WHO. (2006). Multi-Country Study on women's health and domestic violence against women. Geneva: World Health Organization.

Wolfe, J. (1993). Social movements and the state in Brazil. Latin American Research Review, $28(1), 248-257$.

Wylie, P. B., Basinger, L. F., Heinecke, C. L., \& Reuckert, J. A. (1976). Approach to evaluating a police program of family crisis intervention in six demonstration cities: Final report. Washington D.C.: National Criminal Justice Reference Service.

Zorn, J. (1999). Women's rights are human rights: International law and the culture of domestic violence. In Counts, D. A., Brown, J., \& Campbell, J. (eds.). To Have and to Hit: Cultural Perspectives on Wife Beating. 2d ed. Urbana: University of Illinois Press.

Zorza, J. (1992). The criminal law of misdemeanor domestic violence, 1970-1990. Journal of Criminal Law and Criminology, 83, 46-72. 


\section{Appendix A}

\section{Interview questions}

1. How would you describe the situation in ES with regard to domestic violence?

(Follow up) Some studies show that the ES is one of the most violent states for victims of domestic violence, why do you think that is? When you think about domestic violence, why do you think things are the way they are? In your opinion, why is the ES considered the most violent state of the country?

2. What role should your institution play with regard to domestic violence?

3. While I know it's difficult because every case is unique, can you describe a typical domestic violence case for me (characteristics of the victim and aggressor)?

4. What happens when a victim arrives here? What is the typical procedure followed? What are the options offered to the victim?

5. What other institutions do you need to interact with while handling a case? Could you describe the nature of these institutional relationships?

6. How long have you worked here? How long have you worked with cases of domestic violence?

7. What is your opinion about the law 11.340/2006, which determines how cases of domestic violence should be handled?

8. (If the respondent worked at the institution prior to 2006) How were cases handled before and after the enactment of the law 11.340/2006? How did your coworkers react to the change?

9. How is a typical case decided? What do you look at when deciding a case?

10. What usually helps or disturbs the continuation of the case?

11. Do you think other people in your department would take the same decision as you? Why?

12. Did you receive any specialized training to work with these types of cases?

13. How is your work environment? How do you feel about working with domestic violence cases?

14. What are the main problems you face today on your job when handling domestic violence cases? Do you have any suggestions to improve this aspect of your work? 


\section{Appendix B}

\section{Court Observation Form}

Date:_____

Name of Court:

\section{Court safety and security:}

- Following questions asked only of the victim advocate

- Is there a separate waiting area for victims and offenders in the court? $\square$ Yes $\square$ No

- Do court officers accompany victims? $\square$ Yes $\square$ No

- Do the size and layout of the court allow victims and offenders to sit separately? $\square$ Yes $\square$ No

Any other comments about the courtroom itself, waiting space, or safety arrangements?

Did advocates talk to victims? __ always __ sometimes __ never __ unclear. _ n n/a

Did defender talk to defendant? __always __ sometimes __ never _ _ unclear _ n n/a

Overall, how would you describe the pace of each case hearing?

What were the most common reasons for adjournment?

Other comments: 


\section{Appendix C}

\section{Case Observation Form}

Type of case (felony, misdemeanor):

Case stage: arraignment pre-disposition disposition/sentencing trial

Compliance monitoring _ unclear _ other:

Session length: start time: end time: is defendant in custody?

Defendant sex: Was a P. Order in effect? Was there a plea offer?

Staff present in courtroom:

$\begin{array}{lccl}\text { Judge } & \text { Yes } & \text { No } & \text { Unclear: } \\ \text { Prosecutor } & \text { Yes } & \text { No } & \text { Unclear: } \\ \text { Dedicated ADA } & \text { Yes } & \text { No } & \text { Unclear: } \\ \text { Public defender } & \text { Yes } & \text { No } & \text { Unclear: } \\ \text { Private defense attorney } & \text { Yes } & \text { No } & \text { Unclear: } \\ \text { Victim advocate } & \text { Yes } & \text { No } & \text { Unclear: } \\ \text { Probation officer } & \text { Yes } & \text { No } & \text { Unclear: } \\ \text { Other } & \text { Yes } & \text { No } & \text { Unclear: }\end{array}$

Victim accompanied: _ defendant _ advocate _ family/friends _ alone _ other.

Did advocates talk to victims? always sometimes never unclear.

Did defender talk to defendant? always sometimes never unclear.

Tone of the judge talking to the victim:

_ stern _ intimidating _ distracted _ caring _ respectful _ impatient _ n $/ \mathrm{a}$

Tone of the prosecutor talking to the victim:

_ stern _ intimidating _ distracted _ caring _ respectful _ impatient _ n/a

Appearance disposition (adjourned/new date, dismissed, pretrial diversion, pled guilty, convicted at trial, no contest):

Sentence (fine/amount, community service, jail/prison/term length, order of protection, restitution/amount, probation/term length):

Judge's admonishments about noncompliance or other behavior: 